\title{
Undiscovered Oil and Gas in the Big Cypress National Preserve -- A Total Petroleum System Assessment of the South Florida Basin, Florida
}

By RICHARD M. POLLASTRO ${ }^{1}$, CHRISTOPHER J. SCHENK ${ }^{1}$, and RONALD R. CHARPENTIER ${ }^{1}$

Open-File Report 00-317

2000

This report is preliminary and has not been reviewed for conformity with the U.S. Geolcgical Survey editorial standards or with the North American Stratigraphic Code. Any use of trade, firm, or product names is for descriptive purposes only and does not imply endorsement by the U.S. Government.

\section{U.S. DEPARTMENT OF THE INTERIOR}

U.S. GEOLOGICAL SURVEY

${ }^{1}$ Denver, Colorado 


\section{CONTENTS}

Abstract 2

Introduction

Terminology

Geologic Summary 6

Oil Production in South Florida Basin and Big Cypress National ?reserve 7

Comparison of 2000 South Florida Basin-Big Cypress Total Petroleum
SystemAssessment to the 1995 USCS Nationa! Oil and Gas Play-Based Assessment

Total Petroleum System Elements of the South Florica Basin 9

South Florida Basin Sunniland-Dollar Bay TTS and Lowe- Cretaccous Shoal-Reef Oil

Assessment Unit 11

$\begin{array}{ll}\text { Overview } & 11\end{array}$

Source Rocks and Thermal Maturity 12

$\begin{array}{lr}\text { Reservoirs } & 12 \\ \text { Seal Rock }\end{array}$

$\begin{array}{ll}\text { Seal Rock } & 14\end{array}$

Burial history and petroleum generation.

$\begin{array}{ll}\text { Geographic Extent and Boundary Conditions } & 14\end{array}$

South Florida Basin Pre-Punta Gorda TPS and Pre-Punta Gorda Delomite Hypothetical
Gas and Oil Assessment Unit

$\begin{array}{ll}\text { Overview } & \text { i6 }\end{array}$

$\begin{array}{ll}\text { Source Rocks and Thermal Maturity } & 17\end{array}$

$\begin{array}{lr}\text { Reservoirs } & 18\end{array}$

$\begin{array}{lr}\text { Seal Rock } & 18\end{array}$

Burial History and Petroleum Generation 19

Geographic Extent and Boundary Conditions 19

Assessment Methodology and Results 20

$\begin{array}{lr}\text { Background } & 20\end{array}$

$\begin{array}{lr}\text { Data Sources } & 21\end{array}$

Lower Cretaceous Shoal-Reef Oil Assessment Enit of the South Florida Basin 22 $\begin{array}{ll}\text { Input Data } & 23\end{array}$

Assessment Results $\quad 24$

Pre-Punta Gorda Dolomite Gas and Oil Assessment Unit of the South Florida Basin 24 $\begin{array}{ll}\text { Input Data } & 24\end{array}$

Assessment Results $\quad 25$

Summary of Total Petroleum System Assessment of Indiscovered Oil
and Gas Resources in South Florida Basin

Comparison of Results of the 1995 USGS Play-Based Assessment to the 2000 Total

Petroleum System-Assessment Unit Assessment, South Florida Basin, :lorida 26

Assessment of Undiscovered Oil and Gas in Big Cypress Nationa! Preserve 27

Richness Factor Allocation of Undiscovered Resources to Bi: Cyoress 27

Summary of Resource Allocation to Big Cypress National Preserve 28

$\begin{array}{ll}\text { Acknowledgments } & 28\end{array}$

$\begin{array}{ll}\text { References Cited } & 28\end{array}$

Figures 1 through 21 - Geology and historical production illustrations, 21 pp.

Tables 1 through 4 -- Numerical assessment results, 4 pp.

Appendix A and B -- Input data assessment form for assessment units, 6 pp.

Appendix C and D -- Monte Cario output for assessment units, 47 pp. 


\title{
Undiscovered Oil and Gas in the Big Cypress National Preserve -- A Total Petroleum System Assessment of the South Florida Basin, Florida
}

\author{
by Richard M. Pollastro, Christopher J. Schenk, and Ronald R. Charpentier
}

\begin{abstract}
Low gravity, high sulfur oils are produced from the Lower Cretaceous Sunniland Formation in two active fields within Big Cypress National Preserve in the South Florida basin, Florida. Cumulative production in these two fields through 1997 was about 23 million barrels of oil (MMBO), which constitutes about 20 percent of the total production in south Florida from the Sunniland play. Oil is sourced mainly from cyclic, organic-rich carbonate units within the Sunniland Formation and generated at low thermal maturity because of the nature of the marine algal kerogen. Interbedded, porous shelf limestones and dolomites form the primary reservoirs and cyclic evaporites throughout the section provide excellent seals. At depths in excess of 15,000 $\mathrm{ft}$, two wells bordering Big Cypress National Preserve have recorded gas and condensate shows and provide evidence for gas potential in the Late Jurassic Wood River Formation.

Two stacked total petroleum systems, each with a single assessment unit, are recognized for the South Florida basin and Big Cypress area. The two petroleum systems are separated stratigraphically by a major regional evaporite seal, the Lower Cretaceous Punta Gorda Formation. The younger petroleum system and corresponding assessment unit above the Punta Gorda seal is designated as the South Florida Basin Sunniland-Dollar Bay Total Petroleum System (TPS) and Lower Cretaceous Shoal-Reef Oil Assessment Unit (AU). The second system below the regional anhydrite seal is the South Florida Basin Pre-Punta Gorda TPS and Pre-Punta Gorda Dolomite Gas and Oil Hypothetical AU. The two assessment units are correlative to the oil and gas plays defined for the 1995 USGS Assessment.

Offshore in the basin's depocenter, source rocks of the Sunniland-Dollar Bay TPS generated low gravity oils during the Paleocene-Eocene and are presently in the main oil generation window; onshore, however, modeling indicates that only 20 percent of oil generated within Sunniland source rocks has been expelled. In the onshore and offshore State waters of the South Florida basin, the mean total undiscovered volume of petroleum resource in the Lower Cretaceous Shoal-Reef Oil AU is estimated at 279 million barrels of oil equivalent (MMBOE) of which $272 \mathrm{MMBO}$ is oil in oil fields. In contrast, non-associated gas comprises $258 \mathrm{MMBOE}$ (1,545 billion cubic feet of gas or $\mathrm{BCFG}$ ) of the $423 \mathrm{MMBOE}$ of mean undiscovered resource volume estimated for the Pre-Punta Gorda Dolomite Gas and Oil Hypothetical AU of the Pre-Punta Gorda TPS. The geology and field-size distributions of plays of the Upper Jurassic Smackover Formation were used as analogs for evaluating the hypothetical Pre-Punta Gorda AU. Undiscovered gas volume of the Pre-Punta Gorda Dolomite Gas and Oil Hypothetical $\mathrm{AU}$ is attributed mainly to deep dolomite, and possible pinch-out, basal clastic
\end{abstract}


reservoirs within the Late Jurassic Wood River Formation that were sourced by organicrich carbonate beds.

Geologic and petroleum system analysis of the South Florida basin indicates that Big Cypress National Preserve is favorably positioned in both assessment units with respect to undiscovered petroleum resource. For example, Big Cypress National Preserve is located along and within the Sunniland fairway and two fields within the Preserve boundaries have a combined total production of greater than $23 \mathrm{MMBO}$. Moreover, wells bordering the Preserve have had significant gas and condensate shows. Because Big Cypress National Preserve is in a location where the geology is favorable for undiscovered oil fields in the Sunniland/Dollar Bay TPS, and for undiscovered gas fields in the Pre-Punta Gorda TPS, the volume percent of resource allocated to Big Cypress was enriched relative to the calculated areal percent of the assessment units.

Using the methodology and approach of the total petroleum system and assessment unit subdivision, we first assessed the undiscovered petroleum resources of the South Florida basin, and then allocated those resources in the area of Big Cypress National Preserve based on a geologic richness factor. The assessment results that follow for the Big Cypress National Preserve, summarized in the table below, are reported as the means of distributions of undiscovered volumes. Also, the actual volume would fall somewhere on the distribution, not necessarily on the mean. For undiscovered oil fields of $\geq 0.5 \mathrm{MMBO}$, we estimated volumes of about $28 \mathrm{MMBO}$, and about $7 \mathrm{BCFG}$ (1.1 $\mathrm{MMBOE}$ ), and 0.4 million barrels of natural gas liquid (MMBNGL). For undiscovered gas fields $\geq 3$ BCFG (0.5 MMBOE), we estimate about $185 \mathrm{BCFG}$ (31 MMBOE) and about $8 \mathrm{MMBNGL}$. The total mean equivalent undiscovered petroleum volume for Big Cypress National Preserve is about $69 \mathrm{MMBOE}$.

\begin{tabular}{|l|c|c|c|c|c|}
\hline \multicolumn{6}{|c|}{ Assessment of Mean Undiscovered Oil and Gas in Big Cypress National Preserve } \\
\hline Assessment Unit & $\begin{array}{c}\text { Oil } \\
\text { (MMBO) }\end{array}$ & $\begin{array}{c}\text { NGL in Oil } \\
\text { and(or) Gas } \\
\text { Fields } \\
\text { (MMBNGL) }\end{array}$ & $\begin{array}{c}\text { Gas in Oil } \\
\text { Fields } \\
\text { (BCFG) }\end{array}$ & $\begin{array}{c}\text { Gas in Gas } \\
\text { Fields } \\
\text { (BCFG) }\end{array}$ & $\begin{array}{c}\text { Total } \\
\text { (MMBOE) }\end{array}$ \\
\hline $\begin{array}{l}\text { Lower Cretaceous } \\
\text { Shoal-Reef Oil }\end{array}$ & 24.01 & 0.15 & 2.54 & -- & 24.58 \\
\hline $\begin{array}{l}\text { Pre-Punta Gorda } \\
\text { Dolomite Gas and } \\
\text { Oil Hypothetical }\end{array}$ & 3.94 & 8.41 & 4.17 & 185.41 & 43.95 \\
\hline
\end{tabular}

Total mean undiscovered resource in million barrels of oil equivalent (MMBOE)

68.53

\section{Introduction}

In 1995, the USGS completed an assessment of undiscovered oil and gas resources for onshore portions and State waters of the United States. As part of this 1995 USGS 
National Oil and Gas Assessment, a geologic play-level assessment was completed for USGS petroleum Province 50, the Florida Peninsula Province (Pollastro, 1995; Pollastro and Viger, 1998). Subsequently in 2000, the US National Park Service requested that the USGS perform an objective, geologic-based assessment of undiscovered oil and gas specifically for Big Cypress National Preserve in south Florida. The present petroleum geology investigation and oil and gas assessment of Big Cypress National Preserve incorporates a different geological approach, referred to as the total petroleum system/assessment unit method, rather than the assessment by play used by the USGS in 1995 (Gautier and others, 1995). The total petroleum system/assessment unit approach is an accepted, effective, proven method used in the recently-released USGS World Petroleum Assessment 2000 (Klett and others, 1997; USGS World Energy Team, 2000) and is comparable to the play-level approach because the assessment unit may also represent a play or group of plays. The advantage of the petroleum system approach is that it incorporates the unit of assessment within the higher level context of the total petroleum system. This allows for a much better understanding of the essential elements and processes within the petroleum system that relate to source, generation, migration, accumulation, and trapping of the undiscovered petroleum resource(s). It is the purpose of this report to assess the undiscovered oil and gas resources on Big Cypress National Preserve over a forecast period of 30 years using the best geological information and scientific theory available to the USGS; however, the USGS did not have access to seismic survey data for the South Florida basin. This geologic assessment is performed by first assessing the undiscovered petroleum resources of the South Florida basin using the methodology and approach of the total petroleum system and assessment unit subdivision, and then further allocating those resources in the area of Big Cypress National Preserve based on a richness factor assigned from the geologic analysis.

\section{Terminology}

Selected terms of particular importance to the USGS assessment of undiscovered resources in total petroleum systems are defined in this section. The definitions are intended to be generally explanatory rather than strictly technical and are from Klett and others (2000), with some modification.

Assessment Unit ( $A U$ ): A mappable volume of rock within the total petroleum system that encompasses fields (discovered and undiscovered) which share similar geologic traits and socio-economic factors. The fields within an assessment unit should constitute a sufficiently homogeneous population that the chosen methodology of resource assessment is applicable. A total petroleum system might equate to a single assessment unit. If necessary, a total petroleum system can be subdivided into two or more assessment units in order that each unit is sufficiently homogeneous to assess individually.

Associated/Dissolved Gas: Natural gas that occurs in an oil field, either as a free gas cap or in solution; synonymous with gas in oil fields. 
Barrels of Oil Equivalent (BOE): A unit of petroleum volume in which the gas portion is expressed in terms of its energy equivalent in barrels of oil. For this assessment, 6,000 cubic feet of gas equals 1 barrel of oil equivalent (BOE).

Cumulative Petroleum Production: Cumulative volume of petroleum that has been reported. Cumulative oil, cumulative gas, and cumulative production are sometimes uses as abbreviated forms of this term.

Field: A production unit consisting of a collection of oil and gas pools that when projected to the surface form an approximately contiguous area that can be circumscribed.

Field Growth: The increases in known petroleum volume that commonly occur as oil and gas fields are developed and produced. The terms field growth and reserve growth are used interchangeably.

Gas Field: A field with a gas to oil ratio of 20,000 cubic feet/barrel or greater.

Gas in Gas Fields: Gas volumes in gas fields.

Gas in Oil Fields: Gas volumes in oil fields.

Gas to Oil Ratio (GOR): Ratio of gas to oil (in cubic feet/barrel) in a field. In this assessment, GOR is calculated using known gas and oil volumes at surface conditions.

Geologic Province: A USGS-defined area having characteristic dimensions of perhaps hundreds to thousands of kilometers encompassing a natural geologic entity (for example, sedimentary basin, thrust belt, delta) or some combination of contiguous geologic entities.

Liquids to Gas Ratio (LGR): Ratio of total petroleum liquids (including oil, condensate, and natural gas liquids) to gas (in barrels/million cubic feet) in a gas field. The LGR is calculated using known petroleum liquids and gas volumes at surface conditions. This ratio is used to assess the liquid co-products associated with undiscovered gas in gas fields.

Minimum Field Size: The smallest field size (volume of oil in oil fields or volume of gas in gas fields) that is considered in the assessment process. A minimum field size greater than or equal to 0.5 million barrels of oil or oil equivalent is defined for each assessment unit.

Natural Gas Liquids (NGL): Petroleum that occurs naturally as a gas in the reservoir, but as a liquid under surface conditions. Natural gas liquids are typically reported separately from crude oil. 
Natural Gas Liquids to Gas Ratio (for oil fields): Ratio of natural gas liquids to gas (in barrels / million cubic feet) in an oil field, calculated using known natural gas liquids and gas volumes at surface conditions. This ratio is used to assess the natural gas liquids associated with undiscovered gas in oil fields.

Nonassociated Gas: Natural gas that occurs in a gas field. Synonymous with gas in gas fields.

Oil Field: A field with a GOR less than 20,000 (in cubic feet/barrel).

Oil in Gas Fields: Oil volumes in gas fields. For this assessment, oil in gas fields was calculated along with other liquids rather than separately.

Oil in Oil Fields: Oil volumes in oil fields.

Petroleum: A collective term for oil, gas, natural gas liquids, and tar.

Play: A set of known or postulated oil and gas accumulations sharing similar geologic, geographic, and temporal properties, such as source rock, migration pathway, timing, trapping mechanism, and hydrocarbon type. A play differs from an assessment unit: an assessment unit can include one or more plays.

Total Petroleum System (TPS): A mappable entity encompassing genetically related petroleum that occurs in seeps, shows, and accumulations (discovered or undiscovered) that have been generated by a pod or by closely related pods of mature source rock, together with the essential mappable geologic elements (source, reservoir, seal, overburden rocks) that controlled fundamental processes of generation, migration, entrapment, and preservation of petroleum.

Undiscovered Petroleum Resources: Resources postulated from geologic information and theory to exist outside of known oil and gas fields.

\section{Geologic Summary}

Big Cypress National Preserve is located in the southern part of the Florida Peninsula and within the South Florida basin (Fig. 1). The South Florida basin is a structurally simple basin containing a thickness of as much as $25,000 \mathrm{ft}$ or more of sediment and is the area of greatest petroleum potential in the Florida Peninsula Province. The depocenter of the basin apparently lies northwest of the Florida Keys under present-day Florida Bay. The basin is bounded by large-scale, positive structural elements, the most prominent being the Peninsular Arch (Fig. 1). The Peninsular Arch is a crystalline basement high of Paleozoic age plunging south-southeast along the axis of the Florida Peninsula that delineates part of the north-northeast boundaries of the South Florida basin. The Peninsular Arch controlled the deposition of Jurassic and Cretaceous sediments that onlap and wedge or pinch out against the arch (Fig. 2). 
Other major positive structural elements include the Florida Escarpment in the offshore Gulf of Mexico which separates the Florida Shelf from the deep Gulf basin. The Florida Escarpment represents a major barrier reef complex of continual reef grow th from the Cretaceous to Recent. A third major structural element that defines the South Florida basin is the Tampa-Sarasota Arch, a 150 mile-long, basement-involved, northeast-southwest trending feature that extends from the Florida coast to the Florida Escarpment. Smaller positive structural elements that directly influenced the type and distribution of carbonate depositional facies within the South Florida basin are the Pine Key Arch and Largo High to the south, and the Lee-Collier Swell, Charlotte High, and 40 Mile Bend High in the more central part of the basin (Fig. 1).

Sedimentation in the South Florida basin kept pace with subsidence, producing nearly continuous carbonate-evaporite deposition from the Jurassic(?) to the present (Fig. 3). The earliest sediments are Late Jurassic (?) marginal clastics, possibly of continental origin (Applin and Applin, 1965); these basal clastics are underlain by Jurassic basement volcanics, most of rhyolitic composition (Barnett, 1975). Onshore, and along the "Sunniland trend" where the Upper Sunniland produces at depths of about 11,500 ft, the sedimentary section is about 15,000 to 17,000 ft thick and consists of about 7,000 to 9,000 ft of Late Jurassic through Early Cretaceous age rocks, 3,000 ft of Late Cretaceous age rocks, and 5,500 ft of Tertiary age rocks (Fig. 3).

The South Florida basin covers some $80,000 \mathrm{mi}^{2}$ and incorporates the southernmost one-third or more of the peninsula of Florida including the Florida Keys and the easternmost Gulf of Mexico. The basin generally has a low $\left(1.0^{\circ}\right.$ to $\left.1.2^{\circ} \mathrm{F} / 100 \mathrm{ft}\right)$ geothermal gradient; however, the gradient of some onshore oil fields may reach $1.5^{\circ} \mathrm{F} / 100 \mathrm{ft}$ (Reel and Griffin, 1971). Onshore, the basin exhibits only subtle structures with no major faults or vertical fractures identified to date. However, more complex structural elements, including basement fault blocks, are believed to exist in the offshore part of the basin, particularly within the latest Jurassic and earliest Cretaceous part of the stratigraphic section (Faulkner and Applegate, 1986). Such structures would provide pathways for hydrocarbon migration and increase the potential for larger accumulations offshore. Moreover, if these structures extend into the onshore portion, a greater potential for larger accumulations than previously interpreted may be expected in the lower part of the stratigraphic section and corresponding assessment unit.

\section{Oil Production in South Florida Basin and Big Cypress National Preserve}

All commerical oil production in the South Florida basin is from the Lower Cretaceous Sunniland Formation. A total of 14 Sunniland oil fields (10 active and 4 abandoned or shut-in) are located in Lee, Hendry, Collier, and Dade Counties. The first Sunniland oil field discovery was the Sunniland field in 1943; the largest field is West Felda field, discovered in 1966, with total production through 1997 of over 44 million barrels of oil (MMBO). Cumulative production for all Sunniland Formation reservoirs through January, 1998 was about 107 MMBO (Table 1). South Florida basin oil production is partially within the Big Cypress National Preserve (Fig. 4). Moreover, as shown in figure 4, production extends outside the Big Cypress Preserve boundaries and within the greater Big Cypress Swamp drainage area (Big Cypress Area Management 
Task Force, 1984). Presently, two active oil fields of substantial size, Bear Island and Racoon Point fields, and two small inactive oil fields, Pepper Hammock and Baxter Island, lie entirely or partly within the boundaries of Big Cypress National Preserve (Fig. 4). Additionally, a third major field, Sunniland field, and a fourth inactive field, Seminole field, lie within the greater Big Cypress Swamp drainage; the inactive Forty Mile Bend field borders Big Cypress to the southeast (Fig. 4). Total oil production through 1997 within Big Cypress National Preserve, mostly from Bear Island (11.6 $\mathrm{MMBO}$ ) and Racoon Point (11.6 MMBO) fields, is about 23.2 MMBO. Additionally, the full geographic extent of Racoon Point field has yet to be defined since no dry holes have been drilled (Lloyd, 1991). Although no new exploration wells have been drilled on Big Cypress National Preserve within the last decade, a total of five single horizontal legs have been added to pre-existing vertical wells within Bear Island and Racoon Point fields resulting in increased total production for both fields (Ed Garrett, personal commun., 2000, Florida Geological Survey).

\section{Comparison of 2000 South Florida Basin--Big Cypress Total Petroleum System Assessment to the 1995 USGS National Oil and Gas Play-Based Assessment}

The 1995 USGS National Oil and Gas Assessment (1995 USGS Assessment) of technically recoverable, undiscovered oil and gas resources in the US onshore and State waters (Gautier and others, 1985) was based on the best scientific geological information and theory available to the USGS at that time. Assessments of undiscovered oil and gas by the USGS rely largely upon published and commercially available data. Seven major data sources were used in the 1995 USGS Assessment and updates of these sources, where possible, were used in the present assessment of Big Cypress National Preserve. These data sources include both published and unpublished USGS data; Significant Oil and Gas Fields of the United States database commercially available from NRG Associates, Inc. (NRG); the Well History Control System (WHCS) database commerically available from IHS Energy Group, Denver, Colorado; production and other data from the literature; State records; proprietary company reports; and other data obtained by USGS geologists. In addition, it should be particularly noted that this petroleum system assessment of the South Florida basin and Big Cypress National Preserve was not based on seismic prospect evaluation, because seismic survey data was not available to the USGS.

The hydrocarbon play served as the basic unit of assessment for the 1995 USGS Assessment. Six conventional plays were defined for Province 50, the Florida Peninsula Province, and within the South Florida basin (Pollastro, 1995; Pollastro and Viger, 1998). A play consists of a group of geologically related petroleum accumulations. Particular emphasis in play analysis is placed on similarities of the rocks in which the accumulations occur (Schmoker and Klett, 2000). Two of the 6 plays defined in the 1995 USGS Assessment of the South Florida basin are confirmed, or proven, plays: the Upper Sunniland Tidal Shoal Oil play (1995 USGS Assessment code 5001) and Lower Sunniland Fractured Dark Carbonate Oil play (5002) (Pollastro, 1995; Pollastro and Viger, 1998). The remaining four plays were hypothetical: the Dollar Bay Shoal-Reef Dolomite Oil play (5003), Lower Cretaceous Carbonate Composite Oil play (5004), Extended Upper Sunniland Tidal Shoal Oil play (5005), and Wood River Dolomite Deep 
Gas play (5006). All plays other than the Wood River Dolomite Deep gas play (5006) were assessed in the 1995 USGS Assessment. At the time of the 1995 USGS Assessment, Play 5006 had too low of a probability for the discovery of oil and gas to be quantitatively assessed (Pollastro, 1995).

For the present analysis of Big Cypress National Preserve, we applied a different approach in defining the basic level of assessment of domestic undiscovered oil and gas. Here we use subdivisions of the total petroleum system (TPS), termed assessment units (AU), a method used and described in the USGS World Petroleum Assessment 2000 (Magoon and Schmoker, 2000). A TPS might equate to a single AU or, if necessary to achieve homogeneity with respect to geology or discovery history, be subdivided into two or more assessment units. An assessment unit is thus a mappable volume of rock sharing similar geologic traits within the TPS (Schmoker and Klett, 2000). Therefore, an assessment unit may actually define a play or may constitute a specific group of plays within the TPS.

In this petroleum assessment of Big Cypress National Preserve, two stacked petroleum systems, each with a single assessment unit, are designated for the South Florida basin and Big Cypress area. The two TPS are represented in the stratigraphic section of figure 3. The two TPS are separated stratigraphically by a major regional evaporite seal, the Lower Cretaceous Punta Gorda Formation. The younger TPSassessment unit is designated as the South Florida Basin Sunniland/Dollar Bay TPS (USGS code 505001) and corresponding Lower Cretaceous Shoal-Reef Oil Assessment Unit (50500101). The second and older total petroleum system is the South Florida Basin Pre-Punta Gorda TPS (505002) and corresponding Pre-Punta Gorda Dolomite Gas and Oil Hypothetical Assessment Unit (50500201). The two assessment units are correlatable to the plays defined for the 1995 USGS Assessment (Pollastro, 1995) and are also shown in figure 3. The Lower Cretaceous Shoal-Reef Oil AU corresponds to 1995 USGS Assessment plays 5001, 5002, 5003, and 5005. Similarly, the Pre-Punta Gorda Dolomite Gas and Oil Hypothetical AU corresponds to plays 5004 and 5006.

\section{Total Petroleum System Elements of the South Florida Basin}

The total petroleum system is comprised of four critical elements: source, reservoir, seal, and trap. In the petroleum producing formations of south Florida, most traps are stratigraphic in nature; however, deposition of the reservoir facies was controlled, in part, by basement relief. Specific units identified as a critical rock-unit element(s) of the petroleum system are shown in figure 3. Formations or units having petroleum potential in the South Florida basin range in age from Late Jurassic (?) through Early Cretaceous and are also identified in the stratigraphic column of figure 3 . The youngest rocks identified as having potential for petroleum generation and accumulatiion are within the Lower Cretaceous Dollar Bay Formation of the Big Cypress Group, and the oldest are of Late Jurassic age immediately overlying basement rocks.

Source rocks of the South Florida basin are mainly fine-grained, organic-rich carbonates; these source rocks may occur as thick, dark-colored units or as multiple thin or laminated beds within one formation or member. Source rocks are commonly beds within the same formation as the producing reservoir(s). Oils of the South Florida basin can be classified as one "superfamily" of oil and commonly contain high (2-4 percent) 
sulfur. In a recent detailed study, however, J.G. Palacas (USGS, personal commun., 2000) identified four distinctive stratigraphic oil sub-types from oils collected from field production and from oil shows in wells throughout the South Florida basin. These oil sub-types were designated as Dollar Bay sub-type (A), Lake Trafford sub-type (B), Sunniland sub-type (C), and Wood River sub-type (D), and were probably derived from slightly different organic facies (Fig. 3). Sub-type A, Dollar Bay oil, is the least mature oil averaging about $17^{\circ}$ API gravity. Sub-type C, Sunniland oils, average about $26^{\circ}$ API gravity, and mature condensate of sub-type D, Wood River oil, is about $52^{\circ}$ API gravity.

Reservoir rocks of the South Florida basin total petroleum systems are mainly porous carbonate grainstones and dolomites; however, a potential for gas in pinch-outs of deep, Late Jurassic basal clastics must also be considered. Grainstone reservoirs are commonly porous (10-30 percent) and permeable, skeletal bioclastic shelf carbonates deposited as rudistid shoals, banks, mounds, and beach facies in a tidal flat or back reef environment (Halley, 1985; Mitchell-Tapping, 1986, 1987; Richards, 1988). Other depositional grainstone facies include patch reefs. Many of these bioclastic grainstones were deposited on subtle bathymetric highs that likely reflect basement-involved structure or differential basement erosional features. Grain constituents consist of mollusk (rudistid) fragments, pellets, forams, ooids, and peloids. Large skeletal fragments are almost exclusively rudistids. Commonly, skeletal fragments of the shoals or mounds have been leached by subaerial exposure leaving large pores. Dolomitic reservoirs usually consist of fine-grained, sucrosic dolomite with high intercrystalline porosity. These reservoirs were originally skeletal grainstones, packstones, and wackestones that were diagenetically replaced by dolomite (MitchellTapping, 1986, 1987; Richards, 1988). Figure 5 shows the general relationship between reservoir type, porosity, and permeability in the limestone and dolomite reservoirs of the Dollar Bay Formation of the South Florida basin.

Seal rocks, mainly evaporites and impermeable ("tight") micritic carbonates are common throughout the stratigraphic column of the South Florida basin (Fig. 3); multiple seals can be present within any one formation. Anhydrite and salt of the Punta Gorda Formation form the major regional seal throughout the South Florida basin. All seals within, or overlying, petroleum-producing formations of the South Florida basin are highly efficient. This is particularly demonstrated by the criteria for subdivision of oil sub-types among producing units, and the remarkable well-to-well correlation of these oils, often where reservoirs are stratigraphically juxtaposed to one another but separated by a seal (Fig. 3).

Two total petroleum systems and corresponding assessment units are designated here for the South Florida basin and Big Cypress National Preserve. They are 1) the Sunniland/Dollar Bay TPS (505001) and Lower Cretaceous Shoal-Reef Oil AU (50500101), and 2) the Pre-Punta Gorda TPS (505002) and Pre-Punta Gorda Dolomite Gas and Oil Hypothetical AU (50500201). As mentioned previously, the two assessment units closely correspond to two specific groupings of the 6 plays identified for the 1995 USGS Assessment (Pollastro, 1985; Pollastro and Viger, 1998). 
South Florida Basin Sunniland-Dollar Bay TPS and Lower Cretaceous Shoal-Reef Oil Assessment Unit

\section{Overview}

The Sunniland/Dollar Bay TPS and Lower Cretaceous Shoal-Reef Oil AU is a composite of stratigraphic units that incorporate all mature source rock, and all reservoir rocks, seal rock, and accumulations within the Dollar Bay, Lake Trafford, and Sunniland Formations. Additionally, petroleum system elements from other formations of the Big Cypress and Ocean Reef Groups are included in the TPS and assessment unit (Fig. 3). The geographic boundaries of the Sunniland/Dollar Bay TPS and Lower Cretaceous Shoal-Reef Oil AU are outlined in figure 6. Three of the four stratigraphic plays (5001, 5002, and 5005) of the 1995 USGS Assessment (Pollastro, 1995); Pollastro and Viger, 1998) that comprise the Lower Cretaceous Shoal-Reef Oil AU apply to the Sunniland Formation; the fourth play (5003) applies to the Dollar Bay Formation. Thus, the boundaries of the assessment unit define a geographic area of potential discoveries for all accumulations within this group of stratigraphic plays. Moreover, the Lower Cretaceous Shoal-Reef Oil AU focuses on discoveries within bioclastic shoals, mounds, and patch reefs within the upper part of the Sunniland Formation and in the Dollar Bay Formation; a small part of undiscovered resource is attributed to accumulations within fractured carbonate of the lower part of the Sunniland Formation. Elements and processes of the Sunniland/Dollar Bay TPS are summarized in the events chart of figure 7.

The Lower Cretaceous Dollar Bay Formation, the uppermost unit of the Big Cypress Group (Fig. 3), is the youngest formation in the onshore portion of the South Florida basin that shows characteristics favorable for petroleum generation and accumulation. The unit lies about $1,500 \mathrm{ft}$ or more above the Sunniland Formation and is as much as $620 \mathrm{ft}$ thick in some parts of the basin. Onshore, the unit ranges in thickness from about $475 \mathrm{ft}$ to $550 \mathrm{ft}$. Numerous wells penetrating the Dollar Bay Formation in south Florida have reported low-gravity $\left(17^{\circ} \mathrm{API}\right)$ oil shows or tarry residues in both limestone biohermal deposits and an upper dolomite section (Winston, 1971); however, undiscovered accumulations are hypothetical since no commercial production has been recorded from the Dollar Bay. Similar to the Sunniland, the Dollar Bay consists mostly of evaporite-carbonate cycles. These evaporite-carbonate beds formed during a transgressive-regressive cycle; some thin beds of calcareous shale, salt, and lignite are also present (Applin and Applin, 1965; Mitchell-Tapping, 1990). In certain areas of the basin, however, limestone is the dominant lithology of the formation. Production in the Dollar Bay Formation will most likely be from leached limestones in the middle part of the formation, or from a dolomite section in the upper part.

Known only in the subsurface, the Lower Cretaceous Sunniland Formation is the basal unit of the Ocean Reef Group (Fig. 3). Onshore, the formation is relatively uniform in thickness and consists of limestone, dolomite, and anhydrite. The upper part of the Sunniland Formation produces heavy, marginally mature crude oils from porous bioclastic debris mounds, banks, and shoals on the eastern margin of the South Florida basin. The region of productive reservoir facies of the upper Sunniland Formation is defined, in part, by eight fields (Bear Island, Corkscrew, West Felda, Lehigh Park, Mid-Felda, Raccoon Point, Sunniland, and Sunoco-Felda) that have each 
produced more than one MMBO and five smaller fields. These smaller fields are abandoned or shut in (Fig. 4). Combined, these fields form an arcuate northwestsoutheast trend, the "Sunniland trend," which is about $20 \mathrm{mi}$ wide and $150 \mathrm{mi}$ long (Figs. 4 and 9). Generally, the updip limit of the Sunniland varies from about 50 to 60 mi northeast of the producing trend. In particular, Big Cypress National Preserve lies within the Sunniland fairway having two active fields of substantial size ( $>10 \mathrm{MMBO})$, Bear Island and Racoon Point, within the Preserve's boundary (Fig. 4).

\section{Source Rocks and Thermal Maturity:}

Oil and tarry residues recorded in Dollar Bay wells are believed by some to have originated within the formation (Palacas, 1978a, b; Winston, 1971). The total organic carbon (TOC) content of the Dollar Bay Formation ranges from very lean to fairly rich, with some beds containing more than 3 weight percent TOC (Palacas, 1978a, b). The Dollar Bay Formation is located updip and to the northeast of the Sunniland trend. This suggests that the unit is thermally immature and has probably not generated hydrocarbons of commercial quality and quantity (Montgomery, 1987). Other studies strongly disagree, however, and predict that the Dollar Bay Formation has been overlooked and should be a considered a primary oil target with good potential (Winston, 1971; Palacas, 1978a, b; Mitchell-Tapping, 1990).

Offshore, in the more central part of the basin where the Dollar Bay Formation lies at depths $>10,000 \mathrm{ft}$, the formation should be more thermally mature. Onshore, API gravities of oil from the Dollar Bay within the Lower Cretaceous Shoal-Reef Oil AU are expected to be low, probably ranging from $15^{\circ}$ to $20^{\circ}$ (Mitchell-Tapping, 1990). Sulfur content is similar to those of Sunniland-type oils (2-4 percent). Moreover, the inferred presence of patch reefs and more complex structures in the Federal offshore, and greater depth and higher thermal maturity of the Dollar Bay Formation in the Federal and State offshore portions of the basin, enhances the potential for new field discoveries and commercial oil production in this portion of the basin.

Oils produced from the Sunniland Formation are immature, having API gravities that range from about $21^{\circ}$ to $28^{\circ}$ and average $25^{\circ}$ to $26^{\circ}$; the gas-to-oil ratio (GOR) is about $85 \mathrm{ft}^{3} / \mathrm{bbl}$ (Palacas, 1984; Palacas and others, 1984; Tootle, 1991). Source rocks include organic-rich, dark laminated limestone beds in the upper Sunniland and a dark, micritic carbonate unit (informally referred to as the dark carbonate interval) in the lower part of the Sunniland Formation. Organic matter in these source beds is mostly hydrogen-rich, amorphous, marine algal, and commonly with high sulfur content. TOC ranges from 0.4 to 12.0 weight percent, and averages about 1.8 percent (Palacas, 1984). Greater than 80 percent of the organic matter within these source rocks is composed of algal-amorphous kerogen (oil-prone, Type IIs) (Palacas and others, 1984). The hydrocarbon-generating potential of the lower Sunniland dark carbonate facies ranges from poor in wells updip from the producing trend where thermal maturities are low, to good just downdip, to excellent near the depocenter of the basin where thermal maturity is greatest (Applegate and Pontigo, 1984).

\section{Reservoirs}

Undiscovered accumulations in the Dollar Bay portion of the assessment unit will most likely be in tidal shoal deposits and patch reefs that were deposited in a tidal flat, 
lagoonal, restricted-marine setting, and in a subtidal platform, open-marine setting (Fig. $8)$. These reservoirs include (1) porous, leached, and dolomitized grainstones in the upper parts of isolated debris mounds, (2) isolated patch reefs in the middle part of the Dollar Bay Formation, and (3) a porous dolomite in the upper part (Mitchell-Tapping, 1990). Measured porosities (from core) of these rocks range from about 10 to 30 percent and permeabilities from 5 to 60 millidarcies. Traps are created because these reservoirs are overlain by impermeable, micritic, tidal flat deposits, and in some cases argillaceous lime mudstones and anhydrite. The formation is underlain by thick, dense nodular and nodular-mosaic anhydrites of the Gordon Pass Formation.

Reservoir facies in the upper Sunniland Formation are bioclastic buildups consisting of fossil-shell hash (skeletal grainstones). These bioclastic buildups represent probable storm deposition as shoals in a regionally restricted, back-reef lagoonal area in the warm, shallow marine shelf setting of the eastern South Florida basin (Fig. 9) during the late Early Cretaceous (Mitchell-Tapping, 1984; 1987). The buildups of tidal shoals were deposited on subtle bathymetric highs probably related to underlying basement structure. Later, the upper parts of many of these shoals were subaerially exposed, leached, and subsequently dolomitized during a low sea-level stand, further enhancing the reservoir quality of the upper porous zones.

Individual bioclastic buildups vary in thickness between about 40 and $100 \mathrm{ft}$ (Means, 1977; Montgomery, 1987). Depth to the upper Sunniland tidal shoal reservoirs in the producing trend is from about 11,200 to 11,600 ft (Fig. 10). Most mounds are sealed by overlying impermeable lagoonal mudstones and wackestones, some of which have been dolomitized. Primary (interparticle) and secondary (dissolution and intercrystalline from dolomitization) porosity ranges from 10 to 25 percent and averages 15 to 18 percent (Mitchell-Tapping, 1984; 1987). Impermeable micritic carbonate and nodular anhydrite beds within the upper Sunniland enclose and seal many of the individual porous reservoir mounds. Moreover, the entire Sunniland Formation is sealed above and below by thick anhydrite units (Fig. 3). Most hydrocarbon traps are stratigraphic; however, some mixed stratigraphic/structural traps have been recognized.

The Lower Cretaceous Shoal-Reef Oil AU of the Sunniland/Dollar Bay TPS includes some potential within the lower Sunniland from the "dark carbonate" unit. The one well Lake Trafford field, Collier County (Fig. 4), has produced commercial quantities (about 300,000 barrels) of oil from the lower Sunniland in fractured limestone, commonly referred to as the rubble zone (Means, 1977), at a depth of about 11,800 ft. Indigenous hydrocarbons are produced from brown and medium-dark-gray micritic and argillaceous limestones with total carbonate content averaging 76 weight percent, and ranging from 50 to 98 weight percent. Matrix porosity of the producing rubble zone from the discovery well, as measured by well logs, is about 9 volume percent, and the pore space is oil-saturated. Core of the rubble zone from the discovery well has been described as burrowed, fractured, and stylolitized (Lloyd, 1991); these characteristics are thought to be responsible for enhancing the porosity and permeability for commercial production. Potentially productive fractured reservoirs are sealed by impermeable, micritic, tidal flat, lime mudstones and underlain by the impermeable Punta Gorda Anhydrite. 


\section{Seal Rock}

Seals are both local and regional and most are intraformational evaporites or impermeable ("tight") micritic carbonates (Fig. 3). Thick evaporites (anhydrite and salt) of the Punta Gorda Formation form the major regional seal throughout the South Florida basin. Moreover, the Punta Gorda regional seal is the primary stratigraphic unit that divides the two total petroleum systems designated here for the South Florida basin (Fig. 3).

\section{Burial History and Petroleum Generation}

Burial history reconstructions and petroleum generation-expulsion models for the Dollar Bay and Sunniland Formations of the South Florida basin are shown in figures 11 and 12, respectively. In the deeper Federal offshore and near the basin depocenter, the Dollar Bay entered the oil window during the Eocene (Fig. 11); however, onshore at Sunniland field, the Dollar Bay has expelled less than 10 percent of generated oil (Fig. 12). Similarly in the basin's depocenter, the Sunniland entered the oil window in late Paleocene/early Eocene and is presently within the main oil generation window (Fig. 11). Modeling of the Sunniland onshore along the "Sunniland trend" shows that oils generated from Sunniland source beds have only expelled about 20 percent of the hydrocarbons (Fig. 12).

\section{Geographic Extent and Boundary Conditions}

Boundaries for the Sunniland/Dollar Bay TPS (505001) and Lower Cretaceous ShoalReef Oil AU (50500101) are shown in figure 6. The area of the pod of active source rock in figure 6 represents a combined minimum thermal maturity for all source units within the Sunniland/Dollar Bay TPS, the oldest and most mature source in this TPS being the lower Sunniland dark carbonate. The minimum mean vitrinite reflectance $\left(R_{\mathrm{o}}\right)$ value used here as an indicator of thermal maturity for carbonate source rocks with Type IIs organic matter (marine, algal, high sulfur) was $R_{o}=0.55$ percent. This minimum $R_{o}$ value delineates source rocks that have generated early, immature $\left(14^{\circ}\right.$ to $17^{\circ} \mathrm{API}$ gravity), high sulfur oil.

The geographic extent of the assessment unit contributed by the Dollar Bay Formation is based on (1) interpretations of well-log data from a series of onshore wells reporting numerous shows (Winston, 1971; J.G. Palacas, USGS, personal commun., 2000) and on (2) the paleoenvironmental reconstructions of Winston (1971) and Mitchell-Tapping (1990) of the reservoir tidal shoal and patch reef facies, and 3) petroleum generation and expulsion modeling of this study and the burial history and depositional environments reported by Faulkner and Applegate (1986).

Big Cypress National Preserve is located in a highly favorable area for hydrocarbon accumulations within the Dollar Bay Formation. Reconstructions of the paleogeography by Mitchell-Tapping (1990) show that Big Cypress lies within a depositional environment of the Dollar Bay that promoted development of patch reefs, shoals, and subaerially leached debris mounds and islands (Fig. 8).

The assessment unit includes a hypothetical extension of bioclastic buildups to the east and south of the present productive Sunniland trend. This hypothetical extension forms a southwest to northeast arcuate trend approximately $20 \mathrm{mi}$ wide and $250 \mathrm{mi}$ long from the State waters of the Marquesas Keys northeast through the Florida Keys 
and along the southeastern Atlantic Coast of the Florida Peninsula to Broward County (Fig. 6). Bioclastic mounds of smaller size than those in the main trend are predicted to have accumulated on subtle structural highs in this updip, less thermally mature area of the basin to the east and far south. Prominent positive structural elements include the Pine Key Arch and the Largo High (Fig. 1 and 6). Some heavy oil shows having low API gravity $\left(10-14^{\circ}\right)$ have been reported in wells in the northern part of assessment unit; however, $22^{\circ}$ API gravity oil was reported in shows from wells near the Marquesas Keys in the west and southernmost part of the assessment unit (Faulkner and Applegate, 1986; Lloyd, 1991). Also, limestone of the upper part of Sunniland may have been replaced by anhydrite in an area between the two locations along the Keys (Fig. 13) where shows have been recorded, thus reducing the probability for new discoveries in this area.

The northern and updip limit for potential Sunniland fields within the assessment unit was delineated by the deposition of micritic limestone of the intertidal, lagoonalmudflat facies of the Sunniland, an area where no bioclastic buildups are expected. Moreover, the dark carbonate source in the lower part of the Sunniland Formation is also absent. The downdip western boundary of the assessment unit north of the Florida Keys is limited by an area where wells show that the Sunniland limestone is replaced by anhydrite. This is best outlined in the isopach of the Sunniland limestone by Ogelsby (1965) shown in figure 13, the cross section reported by Feitz (1976), and the core study and cross sections by Halley (1985). Areas where Sunniland is replaced by anhydrite, but included in the assessment unit, represent potential new field discoveries in the Dollar Bay Formation.

Onshore, the dark carbonate facies of the lower Sunniland Formation varies in thickness from zero at the updip limit of the Sunniland to $>150 \mathrm{ft}$ in the producing trend. Areas incorporated into the assessment unit are those where conditions for the dark carbonate include 1) dark carbonate unit thickness $>60 \mathrm{ft}$ (see Applegate and Pontigo, 1984; Lloyd, 1991) and 2) good source-rock potential (average TOC $>1.5$ weight percent), and 3) evidence of "rubble zone" or fracturing (Montgomery, 1987). The assessment unit allows some potential for small undiscovered fields in the lower Sunniland, particularly northwest of the Lake Trafford field. Expected depths of production for new field discoveries within the lower Sunniland part of the assessment unit are estimated between 10,000 and 13,000 ft.

Exploration and development of the Sunniland Formation has been minimal within the past two decades. Combined geological analysis and a rather limited exploration history with sparse well distribution within this petroleum system and assessment unit, result in a high probability for the discovery of oil accumulations of moderate size in the Sunniland Formation, particularly along the Sunniland trend or fairway.

The boundary of the Lower Cretaceous Shoal-Reef Oil AU was constrained by the State waters political boundary of the State of Florida and the following geologic conditions:

1. the updip limit of Sunniland and Dollar Bay Formations to the north along the Peninsular Arch

2. the northeastern extent of oil shows in the Dollar Bay Formation and absence of lower Sunniland dark carbonate source rock 
3. the updip and eastern transition to marginally mature source beds within Sunniland Formation $\left(R_{0}<5.5\right.$ percent)

4. the southern limit of porous facies and locations of reported oil shows in Sunniland and Dollar Bay Formations

5. western and southeastern limit of Sunniland limestone beyond which it is replaced by anhydrite (Fig. 13)

\section{South Florida Basin Pre-Punta Gorda TPS and Pre-Punta Gorda Dolomite Gas and Oil Hypothetical AU}

\section{Overview}

The Pre-Punta Gorda TPS and corresponding Pre-Punta Gorda Dolomite Gas and Oil Hypothetical AU are outlined on the map of figure 14; stratigraphic elements of the

petroleum system and assessment unit are shown in figure 3. The Pre-Punta Gorda TPS is a hypothetical petroleum system based on geologic interpretation and geochemical evidence that adequate source rock, reservoirs, and seal rock of Late Jurassic and Early Cretaceous age are present below the Punta Gorda Formation in the South Florida basin. The Pre-Punta Gorda TPS and Pre-Punta Gorda Dolomite Gas and Oil Hypothetical AU incorporate the hypothetical Lower Cretaceous Carbonate Composite Oil (5004) and Wood River Dolomite Deep Gas (5006) plays of the 1995 USGS Assessment (Pollastro, 1995; Pollastro and Viger, 1998). However, the Pre-Punta Gorda AU particularly focuses on new field discoveries of deep gas within the Wood River Formation.

Three potential petroleum-producing units exist within this hypothetical assessment unit in the South Florida basin: 1) the Lower Cretaceous "brown dolomite zone" of the Twelve Mile Member of the Lehigh Acres Formation, 2) a potentially porous dolomite unit within the underlying Pumpkin Bay Formation, also Lower Cretaceous, and 3) dolomite of the Late Jurassic Wood River Formation (Fig. 3). The two Lower Cretaceous units are assessed for undiscovered accumulations of oil derived mainly from organic-rich beds in the upper part of the Pumpkin Bay Formation. In contrast, deeper reservoirs within dolomites of the Wood River are expected to contain gas and condensate.

The informally named brown dolomite of the Lehigh Acres Formation lies about 300 $\mathrm{ft}$ below the base of the Punta Gorda Anhydrite and about 1,000 ft below the Sunniland Formation (Fig. 3). The unit is best developed where thickest (about $100 \mathrm{ft}$ ) and most porous (10 to 22 percent) onshore in Charlotte County and surrounding counties, and at a depth of about 12,000 ft . Oil shows are reported, and because it is about 1,000 ft lower in the stratigraphic section than the Sunniland Formation, oils from the brown dolomite are predicted to have API gravities in the range of about $20^{\circ}$ to $50^{\circ}$ and source beds within the Lehigh Acres Formation should have greater thermal maturities than those that produce Sunniland oils.

The Pumpkin Bay Formation is thickest (as much as 1,200 ft thick) in the northern part of the assessment unit, as measured from reference wells in State waters near Charlotte Harbor and onshore in Collier and Hendry Counties, and geochemical and thermal maturity measurements indicate good source-rock potential (Means, 1977; 
Applegate and others, 1981; Palacas and others, 1981; Attilio and Blake, 1983; Faulkner and Applegate, 1986; Applegate, 1987; Montgomery, 1987).

The Upper Jurassic(?) and Lower Cretaceous Wood River Formation is over 2,700 ft thick, most of which is comprised of limestone and dolomite overlying a basal clastic section. The Wood River averages about 1,700 ft thick and is the lowest sedimentary unit in the South Florida basin (Fig. 3); it is considered to include rocks deposited during Louann through Cotton Valley time (Montgomery, 1987). The few wells that have penetrated this formation show that a 100 - to $150-\mathrm{ft}$-thick clastic unit forms the basal part of the Wood River Formation and consists of dark-red shale and fine- to coarse-grained arkosic sandstone and calcareous sandstone (Applegate and others, 1981). These basal clastics possibly represent fan, fan-delta, and fluvial-lacustrine and marine deposits and are equivalent to the basal Fort Pierce Formation of Applin and Applin (1965). Below the basal clastic sequence in Collier County is a rhyolite porphyry with an age of $189 \mathrm{Ma}$. Overlying these clastic rocks is a thick sequence of anhydrite, microcrystalline dolomite, some limestone, and occasional interbedded salt stringers, indicating marine transgression (Applegate and others, 1981; Montgomery, 1987).

One well, the Mobil-Phillips Seminole C, near Seminole field in Hendry County, produced measurable gas (referred to as minor gas production by Montgomery, 1987) and water at depths of about 15,700 ft from perforations in a dolomite zone averaging about 8 percent porosity. Moreover, logs from the well measured higher porosities and increased resistivities just above the perforated section, possibly indicating the presence of gas (Applegate and others, 1981; Palacas and others, 1981; Montgomery, 1987). Although formation damage occurred in the well bore, this well was categorized by the site geologist as having potential for commercial gas production (J. G. Palacas, USGS, personal commun., 1994; 2000). Additionally, shows of gas and condensate having $52^{\circ}$ API gravity were recorded and sampled in the Exxon Collier 20-2 well at Sunniland field, Collier County.

\section{Source Rocks and Thermal Maturity}

Source-rock studies by Palacas and others (1981) suggest that organic-rich beds in the upper Pumpkin Bay Formation are likely source rocks for petroleum that could be reservoired both within the middle and upper part of the Pumpkin Bay and in the porous brown dolomite zone. Palacas and others (1981) identified organic-rich, argillaceous carbonate beds with high (0.43-3.2 weight percent) TOC in the upper Pumpkin Bay and concluded that these beds had the greatest petroleum-generating potential of all rocks older than the Punta Gorda Anhydrite.

The TOC contents of these rocks, however, varies within the basin. Most rocks within the Twelve Mile Member of the Lehigh Acres Formation contain insufficient organic matter (average about 0.3 percent TOC) to have generated commercial amounts of petroleum. Some richer source beds occur within this unit, however, having marginal (about 0.5 weight percent TOC) to good (greater than 2.0 weight percent TOC at West Felda field) source rock.

Potentially commercial gas production reported from the Mobil-Phillips Seminole C well in dolomite of the Wood River Formation near Seminole field, and a good gas/condensate show in the Wood River from the Bass Collier 12-2 well in the Sunniland field, indicate a sufficient source rock in the Wood River Formation. 
Moreover, Palacas and others (1981) measured TOC up to 1.85 percent in thin Wood River intervals and Faulkner and Applegate (1986) found that the Wood River Formation in the Bass Collier 12-2 well contains as much as 1.15 percent TOC at a depth greater than $16,000 \mathrm{ft}$. Marine beds, generally regarded as potential petroleum sources, are predominant within the Wood River. Some evidence also exists for lacustrine deposition in the basal clastics. The depositional environment of the Wood River Formation, especially in the southern areas, probably favored reef growth; thus a combination of source, seal, and reservoir should be present.

The thermal maturation level for oil generation is greater in this assessment unit than in the overlying Sunniland/Dollar Bay TPS. Oils of the Pumpkin Bay are predicted to be marginally to moderately mature having API gravities ranging between $25^{\circ}$ to $50^{\circ}$, with higher GOR than Sunniland oils.

\section{Reservoirs}

Reservoir rocks consist of sucrosic dolomite and exhibit "pinpoint" intercrystalline to vuggy secondary porosity in beds found at least $50 \mathrm{ft}$ below the top of the Twelve Mile Member of the Lehigh Acres Formation. As much as $50 \mathrm{ft}$ of porous dolomite has been found onshore where the brown dolomite zone reaches a maximum thickness of about $100 \mathrm{ft}$. An area having highest potential for discoveries onshore is defined by the porous zones shown by Applegate (1987) in Charlotte, Lee, Hendry, Collier, Highlands, and Glades Counties and adjacent State waters. Oil shows were observed in the Bass Collier 12-2 well in Collier County in dolomite having sonic well-log porosities ranging from 10 to 22 percent and core porosities as high as 18 volume percent. Good potential for new field discoveries is also predicted offshore in both State and Federal waters. In particular, oil stains were noted in wells where about $350 \mathrm{ft}$ of mostly porous dolomite has been penetrated near the Marquesas Keys (Faulkner and Applegate, 1986; Lloyd, 1991).

Core porosities for the Pumpkin Bay are as high as about 20 percent, and sonic welllog porosities measure slightly higher. Porosities are generally lower in the Pumpkin Bay Formation than in potential reservoirs found in younger units.

Although no reservoir studies have been perfomed, documented evidence of good porosities within some lithologies in the Wood River Formation at depths $>15,000 \mathrm{ft}$ suggest the unit has good potential for accumulations of gas in deep reservoirs. Moreover, the thick (1,700 ft on average) section allows for the presence of multiple horizons with reservoir potential. The basal clastics (fan, fan-delta, and fluviallacustrine and marine deposits) of the Wood River Formation are considered possible deep-gas and pinch-out reservoirs along the Peninsular Arch. Porous dolomite, as described in the Mobil-Phillips Seminole $C$ well near Seminole field, where minor gas production was recorded from dolomite having about 8 percent porosity with subsequent log analysis measuring 20 to 23 percent porosity zones, provides further evidence that the Wood River is a potential prospect for new field discoveries of deep gas.

Seal Rock

As in the Lower Cretaceous Shoal-Reef Oil AU, seal rocks are both local and regional and most are intraformational evaporites or impermeable ("tight") micritic carbonates. 
For example, the Wood River Formation contains interbedded anhyrite, salt stringers, and micritic limestones that could act as excellent seals for porous dolomite reservoirs. The Punta Gorda Formation, however, is the major overlying seal for the Pre-Punta Gorda Dolomite Gas and Oil Hypothetical AU. As described earlier, the Punta Gorda Formation is a regional seal that divides the two total petroleum systems in the South Florida basin (Fig. 3).

\section{Burial History and Petroleum Generation}

Burial history reconstructions in relation to petroleum generation for these stratigraphic units in the deeper offshore, South Florida basin are shown in figure 11. In the deeper offshore, oil generation within the Pumpkin Bay was initiated in the latest Cretaceous, whereas oil generation in the Wood River was complete by Late Cretaceous time; Wood River gas generation occurred in this model during the Tertiary. In addition, figure 12 shows the results of a kinetic petroleum formation (expulsion) model for Type IIs kerogen calculated for the deep (total depth of 17,200 ft) Exxon Collier 20-2 well in Sunniland field, Collier County, where shows of gas and condensate were reported. The model used a geothermal gradient of $1.1^{\circ} \mathrm{F} / 100 \mathrm{ft}$ and a mean annual surface temperature of $70^{\circ} \mathrm{F}$. In the modeled well of figure 12 , the uppermost Pumpkin Bay is presently in the peak oil generation phase and has expelled over 60 percent of it's oil. According to the model, the Bone Island Formation has expelled all oil within the past 5 million years and the Wood River Formation expelled all oil by the Late Cretaceous (about $65 \mathrm{Ma}$ ). A summary of the Pre-Punta Gorda TPS linking the essential petroleum system elements and processes is shown in the events chart of figure 15.

\section{Geographic Extent and Boundary Conditions}

The Pre-Punta Gorda Dolomite Gas and Oil Hypothetical AU is delineated by two areas having geologic conditions favorable for discoveries that, when combined, constrain the assessment unit boundary. One area favorable for discoveries is in the northern half of the assessment unit and is centered around the main producing portion of the Sunniland trend; a second favorable area is in the southern half of the assessment unit and lies over the Florida Keys and Florida Bay extending southwest to the Marquesas Keys. The northern part of the assessment unit, mostly in Charlotte, Lee, Collier, and Hendry Counties, includes an area for potential discoveries where Applegate (1987) outlines porous brown dolomite and an area where the Pumpkin Bay Formation is shown to contain live oil in porous (6-16 percent porosity) dolomite. The northern segment of the assessment unit also corresponds to an area of brown dolomite where high porosity is caused by epigenic dolomitization from an active geothermal lineament system (Saul, 1987).

The Pumpkin Bay Formation is mostly limestone except at its northern limit, where it is dolomite. Within the South Florida basin, the Pumpkin Bay is as thick as 1,200 $\mathrm{ft}$ in offshore Florida State waters of Charlotte Harbor; the formation is projected to thicken westward in Federal offshore waters and into the basin depocenter in Florida Bay (Faulkner and Applegate, 1986). Projections suggest that the formation is as much as $1,500 \mathrm{ft}$ thick in this area and that good reservoirs exist within a thick porous dolomite zone (300-350 ft thick; pinpoint intercrystalline to vuggy secondary porosity as great as 25 percent) in the middle to upper part of the formation, at depths from about 12,500 $\mathrm{ft}$ 
to $>15,000 \mathrm{ft}$. Onshore, the Pumpkin Bay Formation is found at depths from about 12,500 to $14,000 \mathrm{ft}$.

The southern part of the assessment unit represents an area of potential discoveries where oil shows are reported from porous ( 25 percent) brown dolomite of the Lehigh Acres Formation. Several oil shows are reported in thick, porous dolomite sections in the southern segment of the assessment unit (Faulkner and Applegate, 1986; Lloyd, 1991), and where potential exists for discoveries in a patch-reef and back-reef facies of the Wood River Formation, as interpreted by Faulkner and Applegate (1986).

Two shows having significant volumes of gas and gas/condensate are reported in porous dolomite of the Wood River Formation in a well at Seminole field and a well at Sunniland field, respectively. Organic geochemistry studies of well samples from the Wood River Formation indicate that the hydrocarbon-generating potential of the unit ranges from poor to excellent (Palacas and others, 1981; Faulkner and Applegate, 1986). Potential new field discoveries within the Wood River Formation may be in porous ( 8 percent or greater) dolomite reservoirs enclosed by anhydrite, salt stringers, and (or) micritic limestone at depths from about 15,000 to 19,000 ft onshore and in State waters. Some potential gas discoveries may lie within the basal clastics, perhaps as pinchouts, along the Peninsular Arch sourced by organic-rich lacustrine beds. The assessment unit includes areas of the southern part of basin where reef growth occurred. It is possible that gas in the Wood River Formation in the area of the Sunniland trend may have originated in deeper parts of the basin and migrated updip. Moreover, published seismic cross sections in Federal offshore areas of the South Florida basin show faulting that extends from basement, through the Wood River, and into the Lower Cretaceous Bone Island Formation (Faulkner and Applegate, 1986). These structures could extend to the onshore and increase trap size and number relative to the stratigraphic traps characteristic of fields producing from the Sunniland Formation.

General geologic and other conditions that constrain the assessment unit boundary include, but are not limited to, the following:

1. western boundary delineated by State waters boundary and general absence of brown dolomite within the Lehigh Acres Formation

2. south-southeastern boundary determined by State-Federal offshore waters boundary

3. northeast boundary is updip limit of Punta Gorda Formation, Wood River Formation, and brown dolomite of the Lehigh Acres Formation.

\section{Assessment Methodology and Results}

\section{Background}

USGS methodology for the assessment of undiscovered conventional oil and gas resources focuses on developing probability distributions of sizes and numbers of undiscovered oil and gas fields within each assessment unit. These distributions are the basis for the calculation of undiscovered oil and gas resources.

There are many approaches to determining the distributions of sizes and numbers of undiscovered oil and fields within an assessment unit, but there are two commonly used methods. The first involves interpretation of geologic prospects from seismic data, the second is an analysis of historic exploration and production information. In the 
Lower 48, the USGS typically does not have access to 2-D or 3-D seismic-survey grids that would allow for the development of a distribution of seismic prospects or prospect leads that can be volumetrically modeled and geologically risked to arrive at distributions of sizes and number of undiscovered oil and gas fields. Rather, we use the existing exploration and production data and the elements and processes of the petroleum system and assessment units (source rocks, timing of generation, migration, reservoirs, traps, seals) as a guide to the estimation of probability distributions of sizes and numbers of undiscovered fields. For hypothetical assessment units, we arrive at the distributions of sizes and numbers of undiscovered fields using analog data sets from assessment units from other basins where the elements of the petroleum system are similar. An assessment based on an analysis of historic production and exploration data may have more uncertainty related to the distributions of sizes and number of undiscovered fields than an assessment based on a distributions of sizes and numbers of geologically-risked prospects interpreted from a set of closely spaced seismic lines. Capturing this geologic uncertainty with probability distributions of sizes and numbers is the crux of resource assessment. The volume of undiscovered oil and gas calculated from these distributions is given as the mean of the distribution, and the uncertainty is demonstrated by the range from the F95 to the F5 of the distribution.

For the assessment of the South Florida basin, the historic exploration and production data are from the Lower Cretaceous Shoal-Reef Oil AU, which contains eight oil fields greater than or equal to $0.5 \mathrm{MMBO}$ and about 220 wildcat wells that can be used to examine past exploration and as a guide to future exploration and potential discoveries. The Pre-Punta Gorda Dolomite Gas and Oil Hypothetical AU is hypothetical, with no discovered oil or gas fields of the minimum size, and only a limited number of wells have partially penetrated the Pre-Punta Gorda part of the sedimentary section: For this hypothetical assessment unit, we utilized analog and exploration production data sets and geologic knowledge from the Upper Jurassic Smackover Formation of the onshore Gulf Coast (Schenk and Viger, 1995). The source, reservoirs, and trapping in the Smackover fields are considered similar to postulated Pre-Punta Gorda fields in the South Florida basin.

\section{Data Sources}

The oil and gas well data were extracted from the IHS WHCS database, including information on total depth, production formation, formation at total depth, perforation zones, production tests, final well classification, and production data. The reserves and production data for oil fields in the South Florida basin were taken from the NRG Associates, Inc., Significant Oil and Gas Fields Database.

USGS methodology requires the actual field size for each discovered oil and gas field. We arrive at the actual sizes of oil and gas fields by combining the "known" field size (cumulative production plus reserves) taken from the NRG Associates, Inc. database with an estimate of reserve growth. Reserve growth of existing fields is estimated using the method of Klett and Ahlbrandt (2000). The algorithm was based on reserve growth of fields in the lower 48 states of the U.S. The addition of the reservegrow th contribution to the known field size produces a grown field size, which we believe is closer to the actual size of an oil or gas field. Grown field sizes were used throughout this analysis. 
Wildcat-well data were derived from the IHS Energy Group (formerly Petroleum Information Corporation or PI) WHCS database. These wells include only those wells designated by initial well classification as wildcat wells, thus they do not include development or infill wells. We use the historical record of wildcat drilling as a proxy for the degree of exploration activity in an assessment unit.

This assessment used two different methods to calculate distributions of undiscovered resources; a Monte Carlo Simulation method (Charpentier and Klett, 2000) and the Analytical Probability Method (Crovelli, 1999) were used to independently test the results of the input data. The two methods produced results to within 0.1 percent of each other at the mean. The results of the Monte Carlo simulations are given in Appendix C and Appendix D.

\section{Lower Cretaceous Shoal-Reef Oil Assessment Unit of the South Florida Basin}

The geologic model for Lower Cretaceous Shoal-Reef Oil AU, as described in the earlier sections on geology and petroleum system elements, is one of reefs, shoals, carbonate mounds, bioherms, and related features, forming mainly stratigraphic traps sourced from organic-rich, calcareous units interbedded with the carbonates. Several stratigraphic horizons contain potential reservoirs in this assessment unit, and the main known hydrocarbon-bearing interval is the Sunniland Formation (Figs. 3, 7); the Dollar Bay Formation is another unit with similar facies development with potential shoal-reef reservoirs.

The data for new field wildcat wells in this assessment unit shows that of the approximately 220 new-field wildcats, about half were drilled in a 15-year period between 1967-1985 (Fig. 17). The number of new-field wildcats per year has dropped dramatically since that period (Figs. 16,17). The data for discovered field size and newfield wildcats (Fig. 18) demonstrates that overall, as is the case in many basins worldwide, the size of oil and gas fields decreases with increasing numbers of wildcats as the larger fields generally are found early in the exploration history of an assessment unit. This relation is clearly shown on the plots of field size and discovery year in figure 19 , where the sizes of discovered fields decreases with time. Plots of cumulative volumes of discovered oil with wildcat wells (Fig. 20) and with discovery year (Fig. 21) demonstrate that, although fields continue to be discovered, the fields are smaller, as shown by the flattening of the curve of cumulative oil volumes.

The exploration and production data illustrate that eight oil fields greater than or equal to minimum size $(500,000$ barrels) were discovered in the assessment unit between 1943 and 1985 and that the rate of discovery has been somewhat constant through time with respect to wildcat drilling. This discovery history also reflects the exploration methods in effect during this time period. Exploration was initially accomplished mainly with rank wildcats and evolved to drilling prospects interpreted from 2-D seismic surveys. The surge in exploration from 1965 to 1980 probably reflects the use of 2-D seismic surveys combined with new concepts related to carbonate porosity and reservoir potential. In the future, exploration may be guided principally by interpretations of 3-D seismic surveys. 


\section{Input Data}

The assessment input data for the Lower Cretaceous Shoal-Reef Oil AU is shown in Appendices A. Details on the data sheets and assessment model are described in Schmoker and Klett (2000). For the entire onshore and offshore State waters of the South Florida basin, a minimum undiscovered field size of $0.5 \mathrm{MMBO}$. This minimum field size was determined after reviewing the historical data for the South Florida basin, in particular, and for the U.S. in general. This value probably represents a minimum economic field size for this area given the characteristics of the hydrocarbons, especially the low API gravities, high sulfur content and water production, and the depths to production.

The historic production data indicates that the median size of fields has decreased through time from $19 \mathrm{MMBO}$ for the first four fields (first discovery half) to $5 \mathrm{MMBO}$ for the second four discovered fields (second discovery half) (Appendix A, p. 1). We estimated that the median size for undiscovered fields would be $5 \mathrm{MMBO}$ for the Lower Cretaceous Shoal-Reef Oil AU. The median size is generally expected to decrease with time, but we feel that the introduction of 3-D seismic data for this assessment unit may help retain the median size to values about $5 \mathrm{MMBO}$.

The next step is to determine the minimum, median, and maximum values of numbers of undiscovered fields in the assessment unit. For the minimum number, we estimated that at least two fields greater than minimum size would be discovered in the assessment unit. For the median number, we estimated that although only 8 fields have been discovered to date, most of the drilling was concentrated in the Sunniland "fairway", and there is much room for exploration for potential reservoirs away from this trend. In addition, although the Sunniland interval remains the most potentially prospective interval in this assessment unit, other stratigraphic intervals, particularly the Dollar Bay Formation, may also have potential for estimating resources. We estimate that the median number of fields remaining to be discovered in the assessment unit is 25 , with a maximum of 75 fields remaining to be discovered. We took into account that some potentially prospective intervals may be stacked, and that exploration may result in one field discovery with several productive intervals; therefore, this avoided any "double counting" of numbers of undiscovered fields in this assessment unit.

Co-product ratios, such as the gas/oil ratio (GOR) and the natural gas liquids NGL/gas ratio (LGR) for oil fields, are important because our methodology uses these ratios to calculate gas in oil fields and NGL in oil fields, which can have significant implications for the economic viability of fields, especially small fields. The co-product ratios are given in Appendix A for the Lower Cretaceous Shoal-Reef Oil AU. Ancillary, such as API gravity, sulfur content, drilling depths, and water depth are also on the input form (Appendix A, p. 2), are used included on the input form.

The input values used in the richness-factor calculations for Big Cypress National Preserve are shown in Appendices A (p. 3) and B (p. 3). As seen on the input form for this assessment unit (Appendix A, p. 3), we estimated that although Big Cypress accounts for 6 percent of the total area of the Lower Cretaceous Shoal-Reef Oil AU, the volume percent of undiscovered resources for Big Cypress ranges from 6 to 12 percent, with a median of 9 percent. This indicates that, in our geologic and petroleum system 
analyses, Big Cypress is positioned favorably with respect to undiscovered resources in this assessment unit.

\section{Assessment Results}

The Monte Carlo simulation, verified by the Analytical Probability Method, provided the following results for the Lower Cretaceous Shoal-Reef AU of the South Florida basin (Table 2): oil in undiscovered oil fields ranges from an F95 (95 percent chance) of $43.22 \mathrm{MMBO}$ to an F5 (5 percent chance) of $615.03 \mathrm{MMBO}$, with a mean volume of undiscovered oil of 272.54 MMBO. The co-product ratios (Appendix A, p. 2) were used to calculate a range of associated gas in undiscovered oil fields from 4.05 BCFG (F95) to 72.43 BCFG (F5), with a mean volume of associated gas of 28.78 BCFG in undiscovered oil fields. Using the NGL to oil ratio, the volume of NGL in oil fields was calculated to range from 0.23 MMBNGL (F95) to 4.52 MMBNGL (F5), with a mean NGL of 1.72 MMBNGL in undiscovered oil fields.

These results indicate that for the Lower Cretaceous Shoal-Reef Oil AU, a mean of about $272 \mathrm{MMBO}$ is undiscovered. With a total of about $120 \mathrm{MMBO}$ already discovered, approximately one third of the oil has been discovered in this assessment unit.

\section{Pre-Punta Gorda Dolomite Gas and Oil Hypothetical Assessment Unit of the South Florida Basin}

The hypothetical Pre-Punta Gorda Dolomite Gas and Oil Hypothetical AU was defined to include undiscovered gas in the Wood River Formation and minor oil accumulations in stratigraphic traps of the Lehigh Acres and Pumpkin Bay Formations, all below the regional Punta Gorda Formation anhydrite seal. Presently, there are no oil or gas fields in this assessment unit; several wells have penetrated the stratigraphic section with a few significant gas and condensate shows in Wood River dolomites. For this assessment unit, we used the geology and field-size distributions of plays of the Upper Jurassic Smackover Formation of the onshore areas of Alabama and Mississippi from the 1995 USGS Assessment (Schenk and Viger, 1995) as analogs for developing the sizes and numbers of undiscovered fields.

\section{Input Data}

The input data for the Pre-Punta Gorda Dolomite Gas and Oil Hypothetical AU are shown in Appendix B. In our analysis of the risk involved with the geologic elements of this assessment unit, we concluded that there was a 10 percent chance that the hydrocarbon charge was inadequate to charge a field of minimum size within the assessment unit. Based on thermal maturity modeling (Figs. 11, 12) and reported gas and condensate shows, we interpret this assessment unit, in contrast to the first, to contain significantly more gas than oil, in terms of equivalent volumes.

Similar to the Lower Cretaceous Shoal-Reef Oil AU, a minimum field size of 0.5 MMBOE was chosen for both undiscovered gas and oil of the Pre-Punta Gorda AU. The Smackover Formation analog provided the geologic basis for the median size of 4 MMBOE, which we adopted for undiscovered gas and oil fields. Smackover Formation fields, as with most field size distributions, show a significant decrease in discovered 
field size with time, and the median size for this assessment unit reflects the downward trend of Smackover field size with time.

The number of undiscovered fields were again based on the numbers of Smackover fields, the geology and petroleum system elements of this assessment unit, and the geographical scale of the assessment unit. We estimate that more gas fields are present than oil fields by three to one. The median number of 25 undiscovered gas fields (Appendix B, p. 1) corresponds to a similar density of Smackover gas fields adjusted for the area of the assessment unit. The median of eight oil fields further implies an assessment unit dominated by gas; oil is postulated only for the younger stratigraphic formations of lower thermal maturity in this assessment unit (Fig. 3).

The co-product ratios and other ancillary data for the Pre-Punta Gorda Dolomite Gas and Oil Hypothetical AU are given in Appendix B. The values used for the allocation of resources to Big Cypress are shown in Appendix B (p. 3). For oil, we estimate that although Big Cypress represents 8 percent of the area of the assessment unit, the range of undiscovered oil volume in Big Cypress Preserve is from 2 to 8 percent of the Pre-Punta Gorda Dolomite Gas and Oil Hypothetical AU total, with a median of 5 percent. These numbers indicate that, for undiscovered oil volumes, the area of Big Cypress is characterized by geology that is less favorable, or poorer, for new discoveries than the assessment unit average. In contrast, the range in gas volume percent for Big Cypress is higher (i.e., "richer") than the assessment unit average (8 percent) with a range from 9 to 15 percent, and a median of 12 percent (Appendix B, p. 3 ). This range higher than the average indicates that, from our geological analysis, the area of Big Cypress National Preserve is on trend for undiscovered gas resources, as it is for oil resources in the Lower Cretaceous Shoal-Reef Oil AU.

\section{Assessment Results}

The Monte Carlo simulation provided the following fully risked results for the PrePunta Gorda Dolomite Gas and Oil Hypothetical AU (Table 2). Oil in undiscovered oil fields has a range $0.00 \mathrm{MMBO}(\mathrm{F} 95)$ to $231.16 \mathrm{MMBO}(\mathrm{F} 5)$, with a mean volume of undiscovered oil of $78.69 \mathrm{MMBO}$. The co-product ratios (Appendix $\mathrm{B}$ ) were used to calculate a range for associated gas in undiscovered oil fields from 0.00 BCFG (F95) to 259.78 BCFG (F5), with a mean volume of associated gas of 83.25 BCFG (13.88 MMBOE) in undiscovered oil fields. Using the NGL to oil ratio, the volume of NGL in oil fields was calculated to range from 0.00 MMBNGL (F95) to 15.94 MMBNGL (F5), with a mean NGL volume of $4.99 \mathrm{MMBNGL}$ in oil fields. The largest undiscovered oil field is expected to be between 4.04 MMBO (F95) to 121.61 MMBO (F5), with a mean expectation of 38.61 MMBO.

For non-associated gas (gas in gas fields), the Monte Carlo simulation and the Analytical Probability Method provided the following results: total non-associated gas volume in undiscovered gas fields ranges from 0.00 BCFG (F95) to 3,951.48 BCFG (F5), with a mean volume of undiscovered non-associated gas of 1,545.41 BCFG (257.57 MMBOE) (Table 2) The LGR (Appendix B) was used to calculate a range of NGL in undiscovered gas fields from 0.00 MMBNGL (F95) to 181.55 MMBNGL (F5), with a mean volume of 68.01 MMBNGL in undiscovered gas fields. In summary, the total mean volume of undiscovered resource in the Pre-Punta Gorda Dolomite Gas and Oil $\mathrm{AU}$ is 423.14 MMBOE. 
The Monte Carlo simulation provides an estimate of the range of mean field size for the largest gas field expected in this assessment unit, which had a range from 76.48 BCFG (F95) to 1,232.37 BCFG (F5) (p. D15), with a mean of 452.11 BCFG (pp. D14, D15). This estimate of the largest expected undiscovered gas field in the entire assessment unit represents a field of about $75 \mathrm{MMBOE}$, an estimated field size that is larger than any field yet discovered in the South Florida basin. The degree of uncertainty of the sizes of undiscovered gas fields is shown by the spread in the resource distribution (Table 2). The zeros in the F95 fractiles reflect that there is a 10 percent chance of no fields >0.5 MMBOE in the Pre-Punta Gorda Dolomite Gas and Oil Hypothetical AU.

\section{Summary of Total Petroleum System Assessment of Undiscovered Oil and Gas Resources in South Florida Basin}

The results of our petroleum system assessment of the South Florida basin are summarized in table 2 . The assessment resulted in a mean volume of undiscovered oil of 272.54 MMBO for the Lower Cretaceous Shoal-Reef Oil AU and 78.69 MMBO for the Pre-Punta Gorda Dolomite Gas and Oil Hypothetical AU. The summed mean values of undiscovered oil resource is 351.23 MMBO for the South Florida basin (272.55 MMBO plus 78.69 MMBO). For gas, the results provide a mean value for undiscovered nonassociated gas of 1,545.41 BCFG (about $258 \mathrm{MMBOE}$ ). For the South Florida basin, the mean value for total associated gas in undiscovered oil fields is 112.56 BCFG (about 19 MMBOE), the mean value for NGL in undiscovered oil fields is about 6.71 MMBNGL, and the mean value of NGL in undiscovered gas fields is 68.01 MMBNGL. The total undiscovered petroleum resource (oil, gas, and natural gas liguids) for the South Florida basin has a mean of 702.20 MMBOE (Table 2).

\section{Comparison of Results of the 1995 USGS Play-Based Assessment to the 2000 Total Petroleum System-Assessment Unit Assessment, South Florida Basin, Florida}

A comparison of results for undiscovered oil and gas resources performed in the last decade (Pollastro, 1995, and this study) for the South Florida basin, and Florida Peninsula Province (USGS Province 50), is summarized in table 3. The current 2000 USGS total petroleum system assessment, using assessment units, results in a total mean resource volume of about $702 \mathrm{MMBOE}$, compared to a total of about $377 \mathrm{MMBOE}$ from the play-based assessment for the 1995 USGS National Oil and Gas Assessment (Pollastro, 1995). Although the present assessment of undiscovered resources of South Florida appears much higher than the 1995 USGS Assessment, the difference is explained in this section.

As described in earlier sections of this report and illustrated in figure 3, four stratigraphic plays, 5001, 5002, 5003, and 5005, of the 1995 USGS Assessment comprise the Lower Cretaceous Shoal-Reef Oil AU (Sunniland/Dollar Bay TPS); three of these plays apply to the Sunniland Formation and the fourth to the Dollar Bay Formation. Similarly, the Pre-Punta Gorda TPS and Pre-Punta Gorda Dolomite Gas and Oil Hypothetical AU incorporates the hypothetical Lower Cretaceous Carbonate Composite Oil (5004) and Wood River Dolomite Deep Gas (5006) plays of the 1995 USGS Assessment (Pollastro, 1995; Pollastro and Viger, 1998). As in figure 3, table 3 also 
shows how the plays defined in the 1995 USGS Assessment relate to the 2000 TPS-AU Assessment of this report.

Collectively, the four plays comprising the Lower Cretaceous Shoal-Reef Oil AU were assessed lower (about 23 percent) in our present 2000 USGS Assessment (279 MMBOE) than as assessed separately and summed (365 MMBOE) in the 1995 USGS Assessment (table 3). The difference is attributed to more heavily weighted discoveries of oil in tidal shoal deposits of the Upper Sunniland Formation, particularly along the main "Sunniland trend" or fairway; the potential for new field discoveries in Dollar Bay Formation shoals and patch reefs thus were reduced from the USGS assessment by Pollastro (1995).

The most significant difference between the current study and the 1995 USGS playbased assessment of the South Florida basin (Pollastro, 1995) is the assessment of the Pre-Punta Gorda Dolomite Gas and Oil Hypothetical AU of the Pre-Punta Gorda TPS. In this assessment unit, a mean total undiscovered petroleum resource was estimated at about $423 \mathrm{MMBOE}$ of which about $258 \mathrm{MMBOE}$ (about 1,545 BCFG), or 61 percent, is non-associated gas. Moreover, about 68 MMBNGL accompanying the gas was calculated from the co-product ratio (Tables 2 and 3). The non-associated gas and NGL of the Pre-Punta Gorda Dolomite Gas and Oil Hypothetical AU were assessed within porous dolomite and possible clastic pinch-out reservoirs in the Upper Jurassic Wood River Formation, - a play which was recognized and defined in the 1995 USGS Assessment but not assessed (Pollastro, 1995).

In summary, a total of about $702 \mathrm{MMBOE}$ undiscovered oil and gas is estimated for the South Florida basin, as compared to a total of about 377 MMBOE from the 1995 USGS Assessment (Pollastro, 1995); an increase of 86 percent. Much of the increase in undiscovered resource is due to our addition of deep, non-associated gas in the Upper Jurassic Wood RiverFormation. In contrast, this assessment resulted in a decrease of mean undiscovered oil in shoal and patch reef reservoirs of the Dollar Bay formation and in the lower Sunniland Formation.

\section{Assessment of Undiscovered Oil and Gas in Big Cypress National Preserve}

\section{Richness Factor Allocation of Undiscovered Resources to Big Cypress}

The richness-factor concept (Crovelli, 1983) allows us to factor in our geologic knowledge of an entire assessment unit to the allocation of resources to a parcel of land that lies within the assessment unit. Basically, we used the geology of each assessment unit to determine the volume percent of undiscovered resources that would be allocated to Big Cypress National Preserve within each assessment unit; the results are shown in table 4 .

The volume of undiscovered oil in oil fields contributed by the Lower Cretaceous Shoal-Reef Oil AU in the Big Cypress National Preserve is $24.01 \mathrm{MMBO}$ (mean), with a range of 3.67 $\mathrm{MMBO}$ (F95) to 56.18 $\mathrm{MMBO}(\mathrm{F} 5)$. For associated gas in oil fields, the mean is $2.54 \mathrm{BCFG}$, and the range is $0.34 \mathrm{BCFG}$ (F95) to $6.53 \mathrm{BCFG}$ (F5). For NGL in oil fields, the mean is $0.15 \mathrm{MMBNGL}$, and the range is $0.02 \mathrm{MMBNGL}$ (F95) to 0.40 MMBNGL (F5) (table 4).

The mean volume of undiscovered oil in oil fields contributed by the Pre-Punta Gorda Dolomite Gas and Oil Hypothetical AU in the Big Cypress National Preserve is 
3.94 $\mathrm{MMBO}$, with a range of $0.00 \mathrm{MMBO}$ (F95) to 12.01 MMBO (F5) (table 4). For gas in oil fields the calculated mean is $4.17 \mathrm{BCFG}$, with a range of $0.00 \mathrm{BCFG}$ (F95) to 13.44 $\mathrm{BCFG}$ (F5). For NGL in oil fields, the mean is $0.25 \mathrm{MMBNGL}$, and the range is 0.00 MMBNGL (F95) to 0.82 MMBNGL (F5). The zero values are the result of the geologic risk applied to the hydrocarbon charge element in this assessment unit. For nonassociated gas in undiscovered gas fields on Big Cypress, the mean is 185.41 BCFG, with a range of $0.00 \mathrm{BCFG}$ (F95) to $480.39 \mathrm{BCFG}$ (F5). For liquids in undiscovered gas fields, the mean is $8.16 \mathrm{MMBNGL}$, and the range is 0.00 MMBNGL (F95) to 21.94 MMBNGL (F5).

\section{Summary of Resource Allocation to Big Cypress National Preserve}

The mean petroleum resource for Big Cypress National Preserve is shown in table 4 and is summarized as follows: 1) the total oil in undiscovered oil fields is $27.95 \mathrm{MMBO}$, gas in oil fields is 6.71 BCFG (1.12 MMBOE), and NGL in oil fields is $0.40 \mathrm{MMBNGL}$; the total gas in undiscovered gas fields is $185.41 \mathrm{BCFG}(30.90 \mathrm{MMBOE})$, and the NGL in gas fields is 8.16 MMBNGL. Our total equivalent mean undiscovered oil and gas resource assessed for Big Cypress National Preserve is 68.53 MMBOE.

For undiscovered oil resources, we estimate that there is about the same magnitude of undiscovered oil as has been discovered to date on Big Cypress; the discovered oil is principally at Raccoon Point and Bear Island fields (Table 1). For non-associated gas, this represents the first assessment of potential undiscovered gas in gas field resources.

\section{Acknowledgments}

We are grateful to several individuals who provided technical information, data, and computer and graphics support. We thank Jim Palacas for providing geochemical data and interpretations on South Florida basin oil types and Michael Lewan for his discussions and assistance in calculating models of oil generation and expulsion. We also thank Tim Klett for preparing the various plots of historical production data, Bob Crovelli for running the Analytical Probability Method calculations, and the USGS Assessment Methodology Team for their assistance in the essential assessment review. Critical reviews by Mitch Henry and Tim Klett, and editing by Kathy Varnes improved the manuscript greatly. We would also like to thank Susan Weiler for GIS support and Wayne Husband for assistance in preparing many of the figures.

\section{References Cited}

Applegate, A.V., 1987, Part II--The Brown Dolomite zone of the Lehigh Acres Formation (Aptian) in the South Florida basin--A potentially prolific producing horizon offshore: Florida Geological Survey Information Circular No. 104, pt. 2, p. 46-66.

Applegate, A.V., and Pontigo, F.A., Jr., 1984, Stratigraphy and oil potential of the Lower Cretaceous Sunniland Formation in south Florida: Florida Bureau of Geology Report of Investigations No. 89, 40 p.

Applegate, A.V., Winston, G.O., and Palacas, J.G., 1981, Subdivision and regional stratigraphy of the pre-Punta Gorda rocks (lowermost Cretaceous-Jurassic?) in 
South Florida: Gulf Coast Association of Geological Societies Transactions, v. 31, p. 447-453.

Applin, P.L., and Applin, E.R., 1965, The Comanche Series and associated rocks in the sub-surface in central and south Florida: U.S. Geological Survey Professional Paper $447,84 \mathrm{p}$.

Attilio, D.E., and Blake, Bruce, 1983, Petroleum potential, exploration possibilities of South Florida basin, Florida Keys: Oil and Gas Journal, v. 81, p. 148-153.

Barnett, R.S., 1975, Basement structure of Florida and its tectonic implications: Gulf Coast Association of Geological Societies Transactions, v. 25, p. 122-142.

Big Cypress Area Management Task Force, 1984, Sensitive natural resources of the Big Cypress Area of Critical Concern, a report to the governor and members of the cabinet, February 21, 1984,69 p.

Charpentier, R.R., and Klett, T.R., 2000, Monte Carlo Simulation Method, in U.S. Geological Survey World Energy Assessment Team, U.S Geological Survey World Petroleum Assessment 2000 --Description and Results, Chapter MC, 15 p., disc one: U.S. Geological Survey Digital Data Series 60, Version 1.0, four CD-ROMs.

Crovelli, R.A., 1983, Probabilistic methodology for petroleum resource appraisal for wilderness lands, Chapter O, in Miller, B.M., ed., Petroleum potential in wilderness lands in western United States: U.S. Geological Survey Circular 902-A-P, p. O1-O5

Crovelli, R.A., 1999, Analytical resource assessment method for conventional oil and gas accumulations -- the "ASSESS" method: U.S. Geological Survey Open-File Report 99-405, 34 p.

Faulkner, B.M., and Applegate, A.V., 1986, Hydrocarbon exploration evaluation of Pulley Ridge area, offshore South Florida basin: Gulf Coast Association of Geological Societies Transactions, v. 36, p. 83-95.

Feitz, R.P., 1976, Recent developments in Sunniland exploration of South Florida: Gulf Coast Association of Geological Societies Transactions, v. 26, p. 74-78.

Gautier, D.L., Dolton, G.L., Takahashi, K.I., and Varnes, K.L., eds., 1995, 1995 National assessment of United States oil and gas resources--Results, methodology, and supporting data: U.S. Geological Survey Digital Data Series DDS-30, one CD-ROM.

Halley, R.B., 1985, Setting and geologic summary of the Lower Cretaceous, Sunniland Field, Southern Florida, in Roel, P.O., and Choquette, P.W., eds., Carbonate Petroleum Reservoirs, Springer-Verlag, New York, p. 445-454.

IHS Energy Group, Well History Control System (WHCS) database, Denver, Colorado. Klett, T.R., and Ahlbrandt, T.S., 2000, Data sources and compilation, in U.S. Geological Survey World Energy Assessment Team, U.S Geological Survey World Petroleum Assessment 2000 --Description and Results, Chapter DS, 15 p., disc one: U.S. Geological Survey Digital Data Series 60, Version 1.0, four CD-ROMs.

Klett, T.R., Schmoker, J.W., Charpentier, R.R., Ahlbrandt, T.S., and Ulmishek, G.F., 2000, Glossary, in U.S. Geological Survey World Energy Assessment Team, U.S Geological Survey World Petroleum Assessment 2000 --Description and Results, Chapter GL, 7 p., disc one: U.S. Geological Survey Digital Data Series 60, Version 1.0, four CD-ROMs.

Klett, T.R, Ahlbrandt, T.S., Schmoker, J.W., and Dolton, G.L., 1997, Ranking of the World's oil and gas provinces by known petroleum volumes: U.S. Geological Survey Open-File Report 97-463, One CD-ROM. 
Lloyd, J. M., 1991, 1988 and 1989 Florida petroleum production and exploration: Florida Geological Survey Information Circular No. 107, p. 1-62.

Magoon, L.B., and Schmoker, J.W., 2000, The total petroleum system -- Natural fluid network that constrains the assessment unit, in U.S. Geological Survey World Energy Assessment Team, U.S Geological Survey World Petroleum Assessment 2000 --Description and Results, Chapter PS, 30 p., disc one: U.S. Geological Survey Digital Data Series 60, Version 1.0, four CD-ROMs.

Means, J.A., 1977, Southern Florida needs another look: Oil and Gas Journal, v. 75, no. 5, p. 212-225.

Mitchell-Tapping, H.J., 1984, Petrology and depositional environment of the Sunniland producing fields of south Florida: Gulf Coast Association of Geological Societies Transactions, v. 34, p. 157-173.

--- 1986, Exploration petrology of the Sunoco Felda trend of South Florida: Gulf Coast Association of Geological Societies Transactions, v. 36, p. 241-256.

-- 1987, Application of the tidal mudflat model to the Sunniland Formation of South Florida: Gulf Coast Association of Geological Societies Transactions, v. 37, p. 415426.

-- 1990, New oil exploration play in Florida--The upper Fredericksburg Dollar Bay Formation: Gulf Coast Association of Geological Societies Transactions, v. 40, p. 607-621.

Montgomery, S.L., 1987, Success and sensibility in South Florida: Petroleum Frontiers, v. $4,52 \mathrm{p}$.

NRG Associates, 1995, The significant oil and gas pools of the United States data base: Colorado Springs, Colorado, NRG Associates, Inc.: database available from NRG Associates, Inc., P.O. Box 1655, Colorado Springs, CO 80901 U.S.A.

Oglesby, W.R., 1965, Folio of South Florida basin - A preliminary study: Florida Geological Survey Map Series No. 19, 3 p.

Palacas, J.G., 1978a, Distribution of organic carbon and petroleum source rock potential of Cretaceous and lower Tertiary carbonates, South Florida basin, preliminary results: U.S. Geological Survey Open-File Report 78-140, 35 p.

--- 1978b, Preliminary assessment of organic carbon content and petroleum source rock potential of Cretaceous and lower Tertiary carbonates, South Florida basin: Gulf Coast Association of Geological Societies Transactions, v. 28, p. 357-381.

--- 1984, Carbonate rocks as sources of petroleum--Geological and chemical characteristics and oil-source correlations: Proceedings of the 11th World Petroleum Congress, 1983 , v. 2, p. 31-43.

Palacas, J.G., Anders, D.E., and King, J.D., 1984, South Florida basin--Prime example of carbonate source rocks of petroleum, in Palacas, J.G., ed., Petroleum geochemistry and source rock potential of carbonate rocks: American Association of Petroleum Geologists, Studies in Geology, v. 18, p. 71-96.

Palacas, J.G., Daws, T.A., and Applegate, A.V., 1981, Preliminary petroleum source-rock assessment of pre-Punta Gorda rocks (lowermost Cretaceous-Jurassic?) in South Florida: Gulf Coast Association of Geological Societies Transactions, v. 31, p. 369376.

Pollastro, R.M., 1995, Florida Peninsula Province (050), in Gautier, D.L., Dolton, G.L., Takahashi, K.I., and Varnes, K.L., eds, 1995 National assessment of United States oil 
and gas resources--Results, methodology, and supporting data: U.S. Geological Survey Digital Data Series DDS-30, One CD-ROM.

Pollastro, R.M., and Viger, R.J., 1998, Maps showing hydrocarbon plays of the Florida Peninsula, USGS Petroleum Province 50: U.S. Geological Survey Oil and Gas Investigations Map OM-226, one 1:1,000,000 map sheet with pamphlet, $8 \mathrm{p}$.

Reel, D.A., and Griffin, GM., 1971, Potentially petroliferous trends in Florida as defined by geothermal gradients: Gulf Coast Association of Geological Societies Transactions, v. 21, p. 31-36.

Richards, J.A., 1988, Depositional history of the Sunniland Limestone (Lower Cretaceous), Raccoon Point field, Collier County, Florida: Gulf Coast Association of Geological Societies Transactions, v. 38, p. 473-483.

Saul, W.L., 1987, Brown Dolomite zone of the Lehigh Acres Formation, Lower Cretaceous, South Florida: Lafayette, La., University of Southwestern Louisiana, Master's thesis, 95 p.

Schenk, C.J., and Viger, R.J., 1995, East Texas basin Province and Louisiana-Mississippi Salt Basins Province, in Gautier, D.L., Dolton, G.L., Takahashi, K.I., and Varnes, K.L., eds, 1995 National Assessment of United States oil and gas resources--Results, methodology, and supporting data: U.S. Geological Survey Digital Data Series DDS-30, One CD-ROM, 95 p.

Schmoker, J.W., and Klett, T.R., 2000, U.S. Geological assessment model for undiscovered conventional oil, gas, and NGL resources--The seventh approximation, in U.S. Geological Survey World Energy Assessment Team, U.S Geological Survey World Petroleum Assessment 2000--Description and Results, Chapter AM, 17 p., disc one: U.S. Geological Survey Digital Data Series 60, Version 1.0, four CD-ROMs.

Tootle, C.H., 1991, Reserves estimated, production listed for Floridas 22 oil fields: Oil and Gas Journal, v. 89, p. 84-87.

U.S. Geological Survey World Energy Assessment Team, 2000, U.S Geological Survey World Petroleum Assessment 2000--Description and Results: U.S. Geological Survey Digital Data Series 60, version 1.0, four CD-ROMs.

Winston, G.O., 1971, The Dollar Bay Formation of Lower Cretaceous (Fredericksburg) age in South Florida, its stratigraphy and petroleum possibilities: Florida Bureau of Geology Special Publication No. 15, 99 p. 


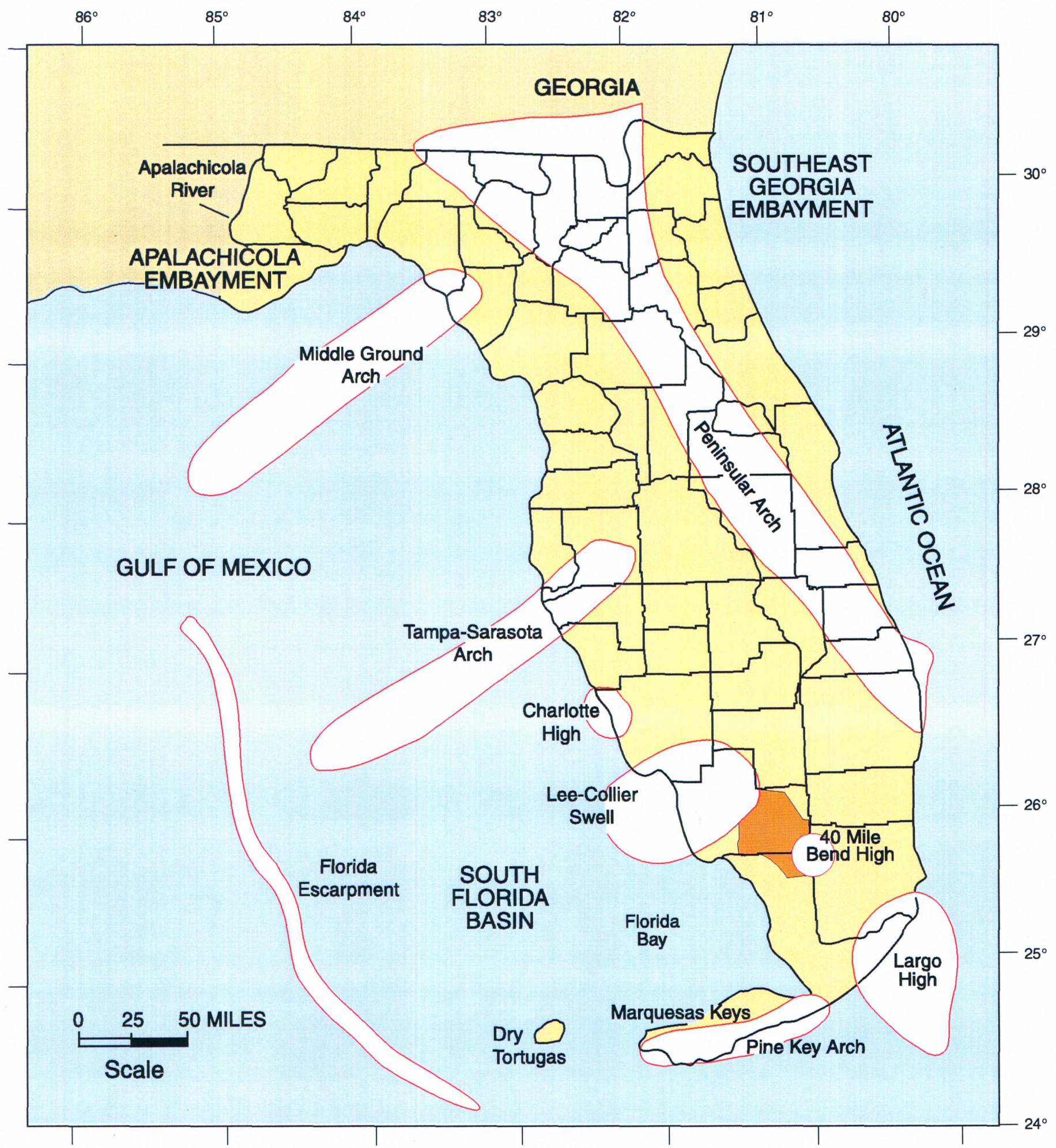

Florida Peninsula Province (USGS Province 50)

Big Cypress National Preserve

Major Positive Structural Elements

Figure 1.-- Map showing Florida Peninsula Province (USGS Province 50) and major positive structural elements of the South Florida basin. 


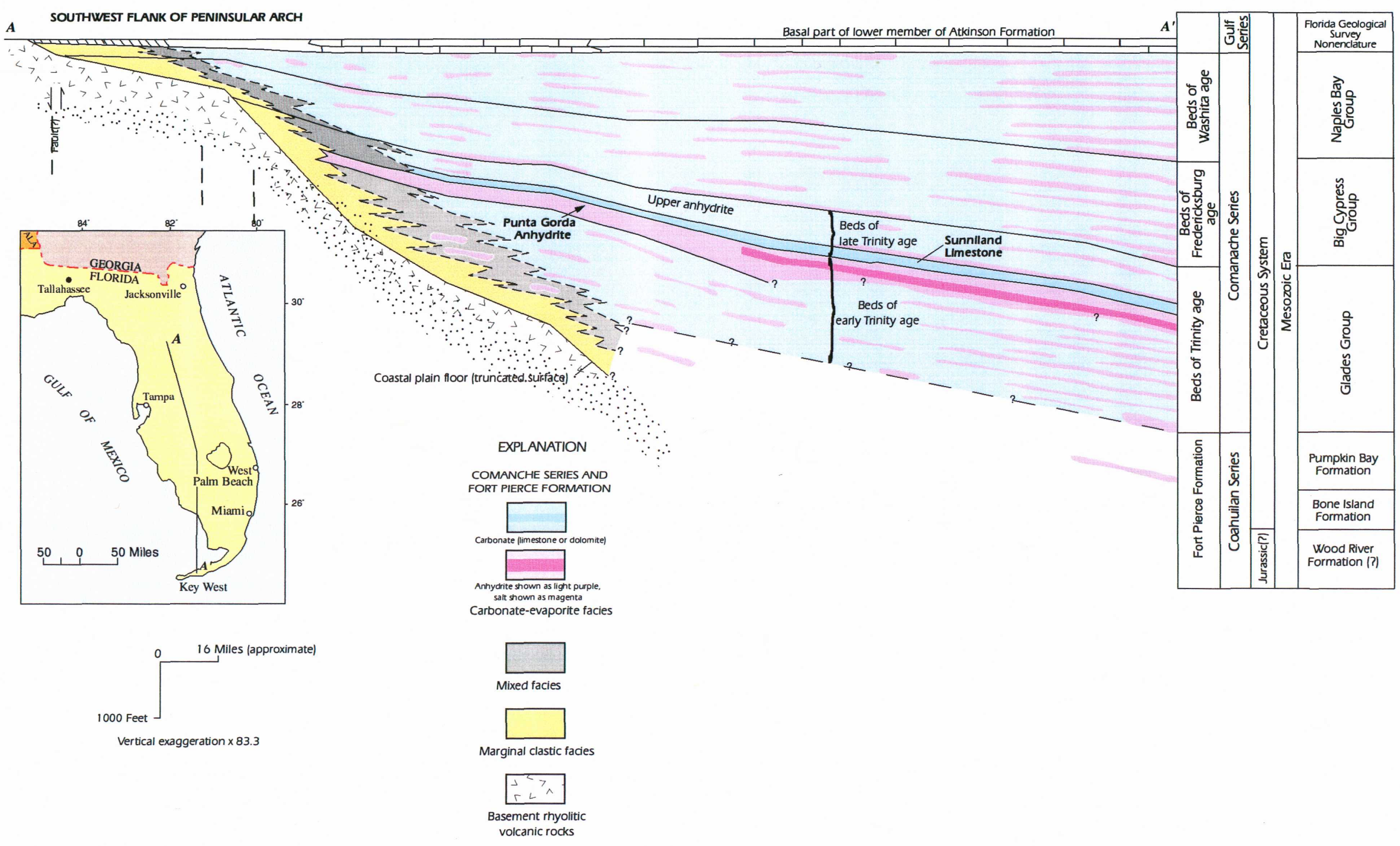

Figure 2. -- Simplified cross section of Late Jurassic and Early Cretaceous age rocks from central Peninsular Arch across South Florida basin to Key West. Stratigraphic nomenclature from Applin and Applin (1965) and Florida Geological Survey. Modified from Applin and Applin (1965). 


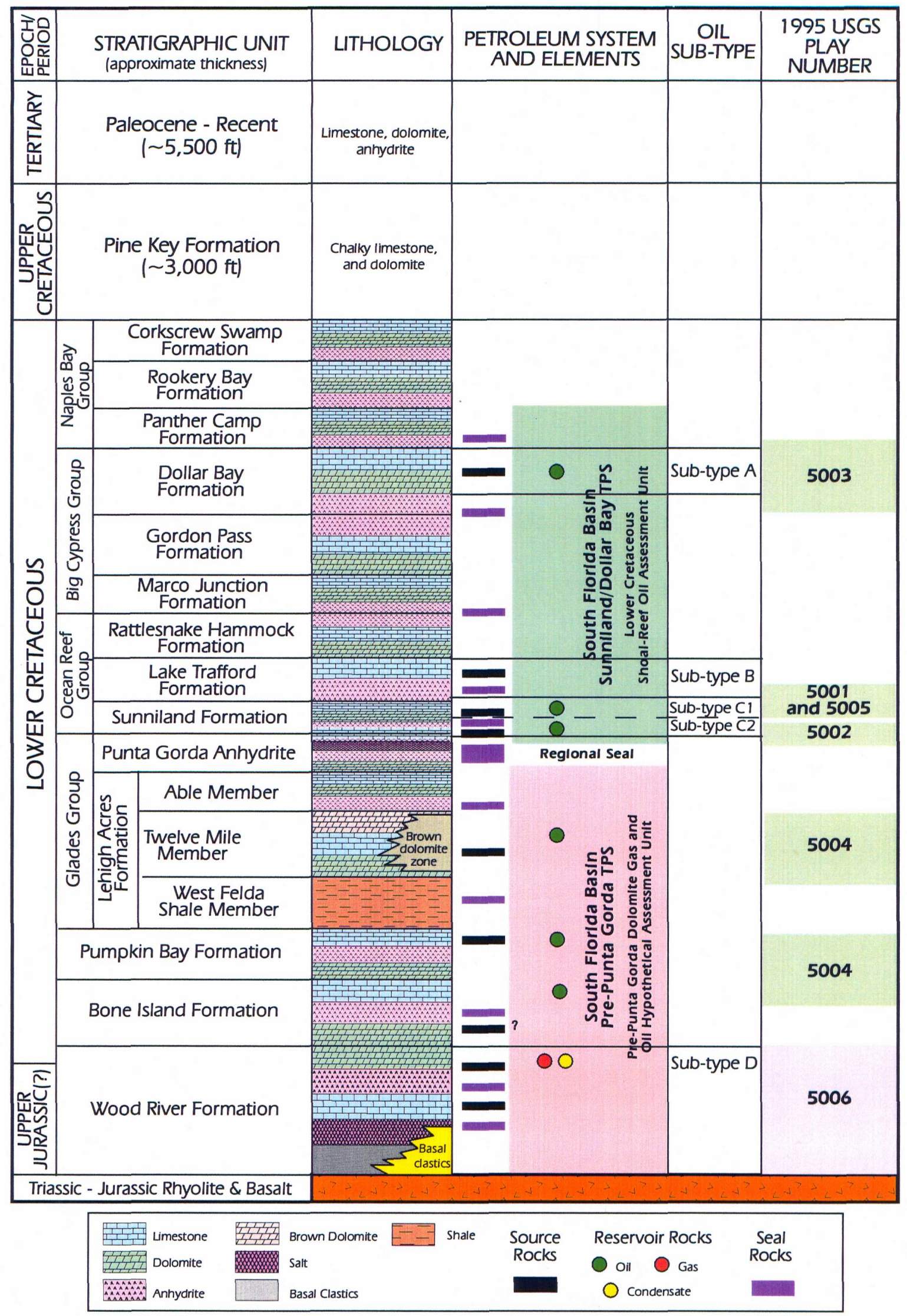

Figure 3. -- Stratigraphic section of South Florida Basin along Sunniland trend showing relation to petroleum system elements, total petroleum systems (TPS), oil sub-types, and 1995 USGS plays. Modified from Faulkner and Applegate (1986). 


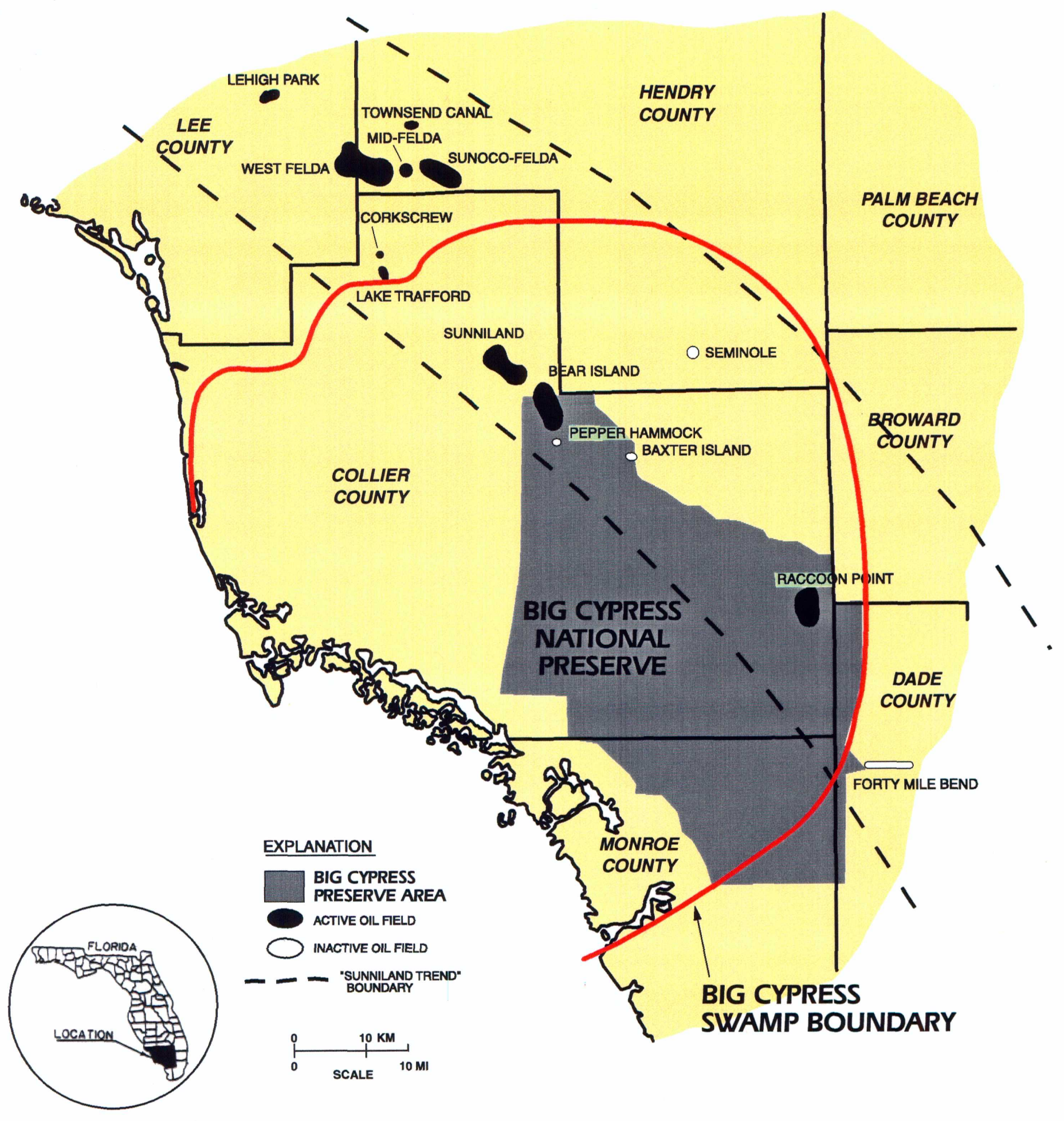

Figure 4. - Names and locations of South Florida active and inactive oil fields in relation to Big Cypress National Preserve and Big Cypress Swamp drainage area. Modified from Lloyd (1991). 


\section{PERMEABILITY (mD)}

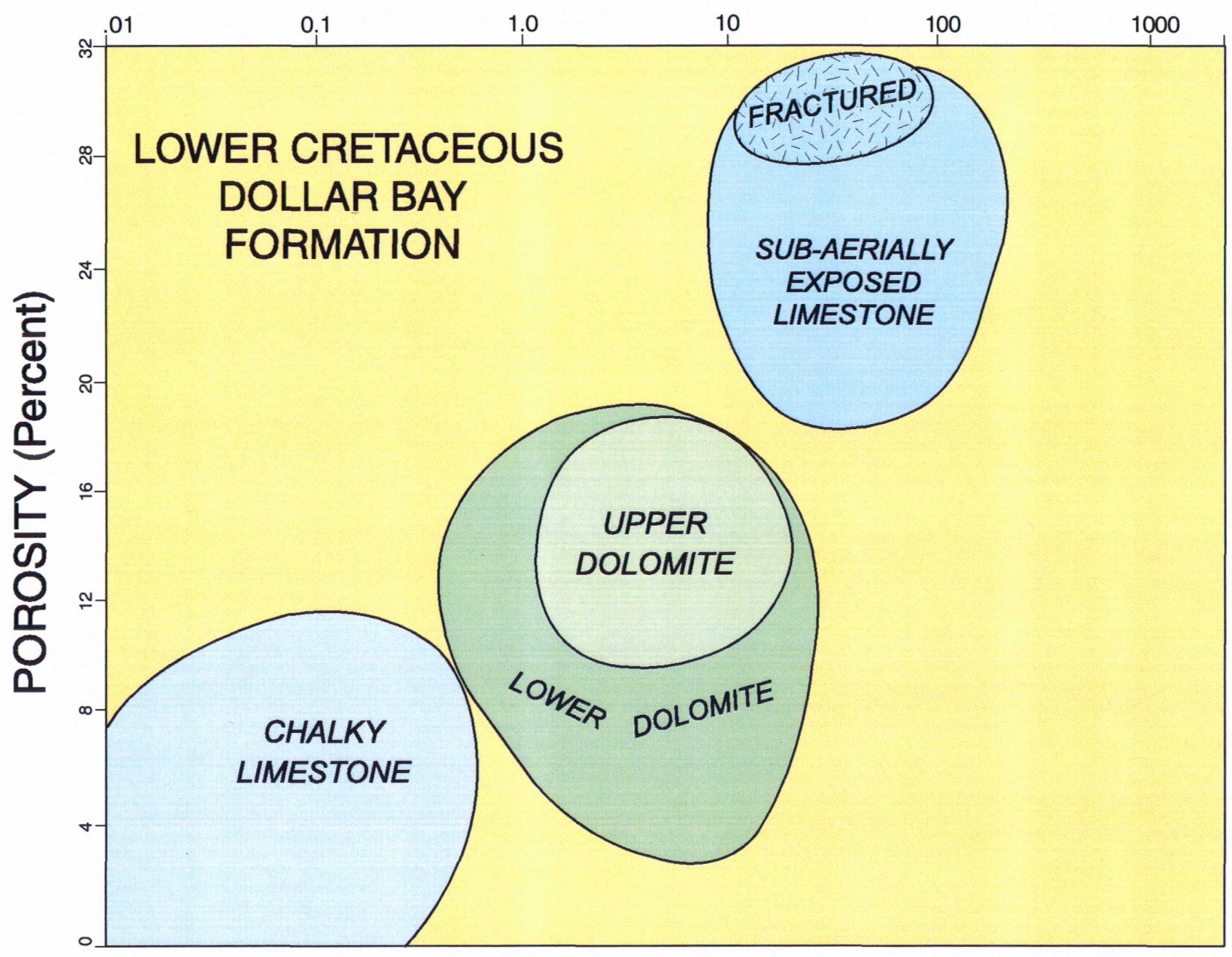

Figure 5. -- Relationship of porosity and permeability to lithology and diagenesis in Lower Cretaceous Dollar Bay Formation, South Florida basin. Modified from Mitchell-Tapping (1990.) 


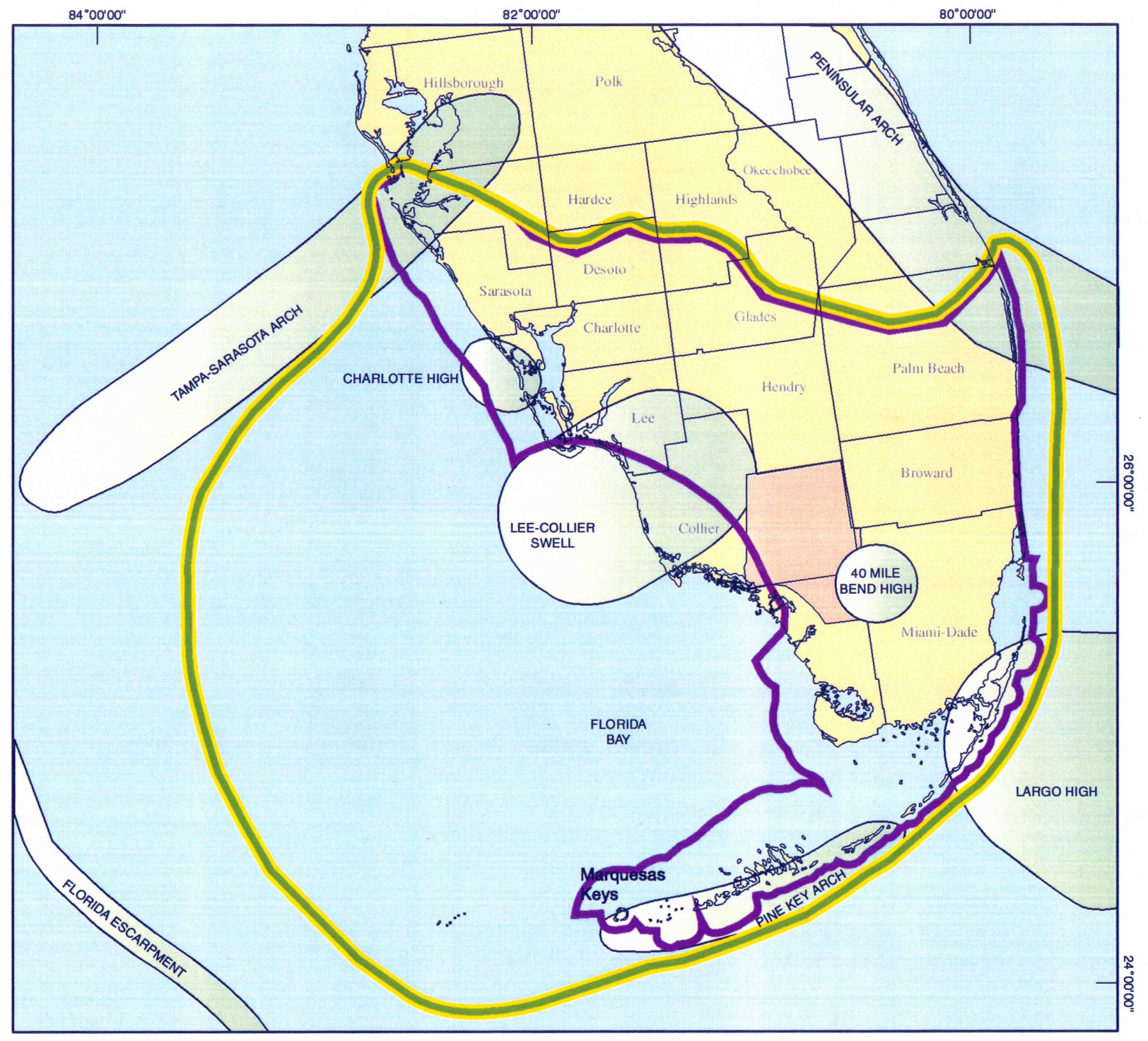

\section{South Florida Basin Sunniland/Dollar Bay TPS}

\section{Lower Cretaceous \\ Shoal-Reef Oil \\ Assessment Unit \\ (50500101)}

Legend:

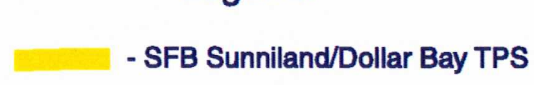

- Pod of Active Source Rock - Lower Cretaceous Shoal Reef Assessment Unit

- Structural Uplift

- Big Cypress National Preserve

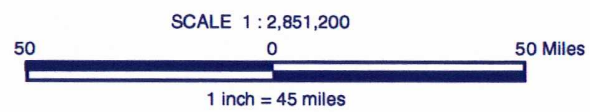

Figure 6. -- Map of South Florida Basin showing boundaries of Sunniland/Dollar Bay Total Petroleum System (TPS) and Lower Cretaceous Shoal-Reef Oil Assessment Unit. 


\section{Total Petroleum System Events Chart}

\section{Province Name: Florida Peninsula (50) TPS Name: South Florida Basin Sunniland/ Dollar Bay TPS (505001)}

Author(s): R.M. Pollastro/C.J. Schenk Date: 6/15/00

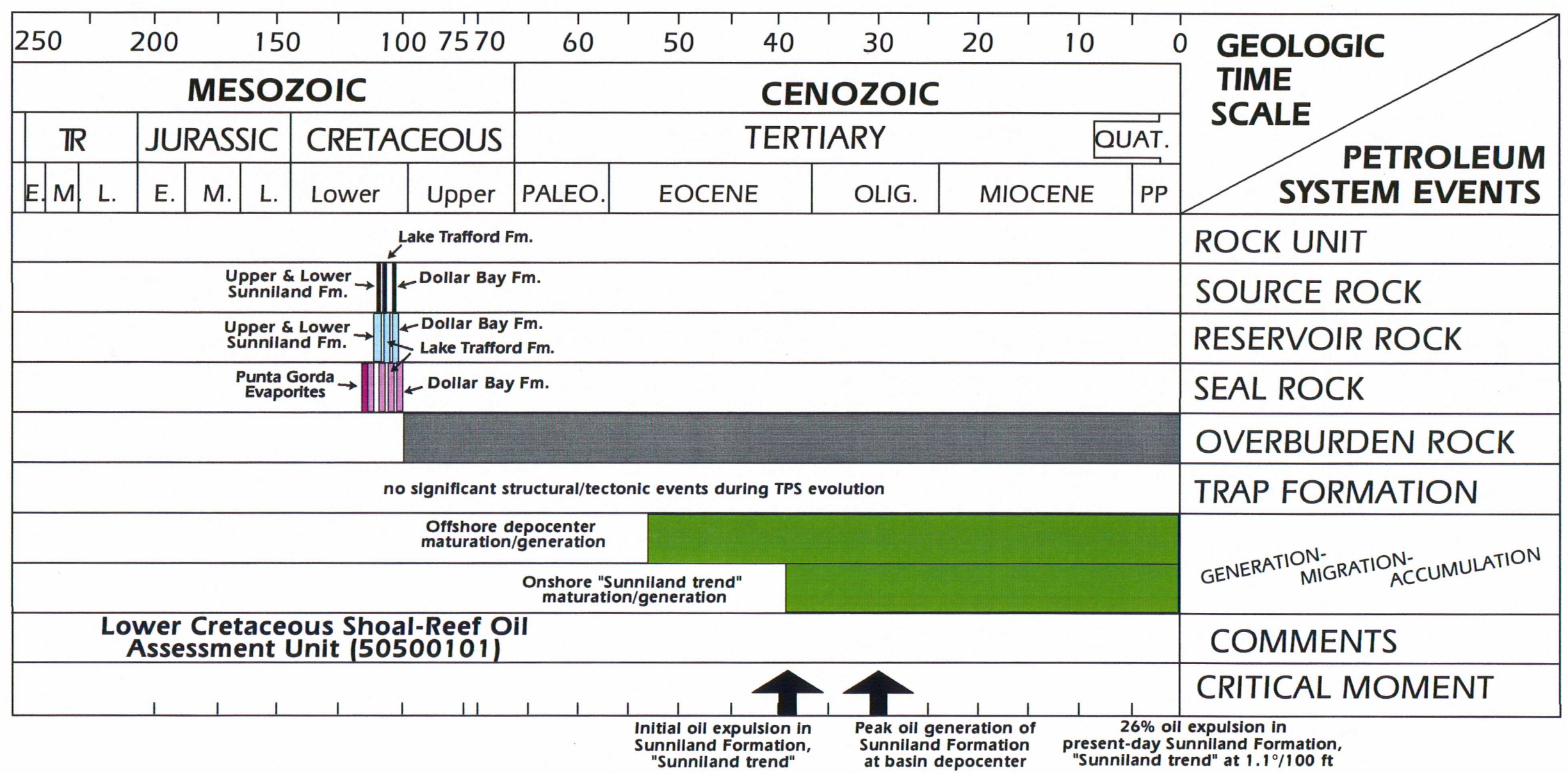

Figure 7.--Total Petroleum System (TPS) events chart for South Florida Basin Sunniland/Dollar Bay TPS and Lower Cretaceous Shoal-Reef Oil Assessment Unit. 


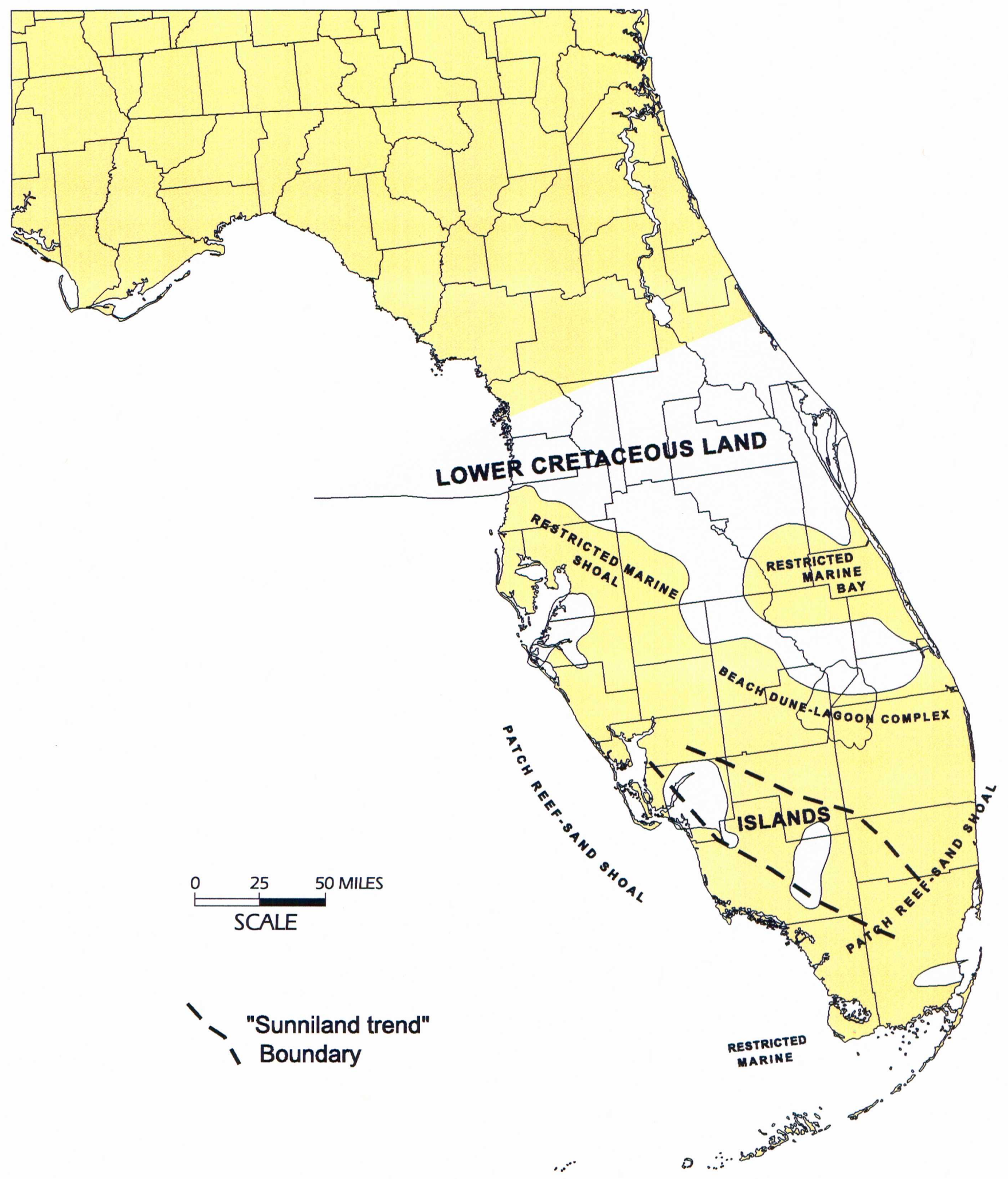

Figure 8.--Reconstructive model of paleoenvironments in southern Florida Peninsula during deposition of Lower Cretaceous Dollar Bay Formation. Modified from Mitchell-Tapping (1990). 


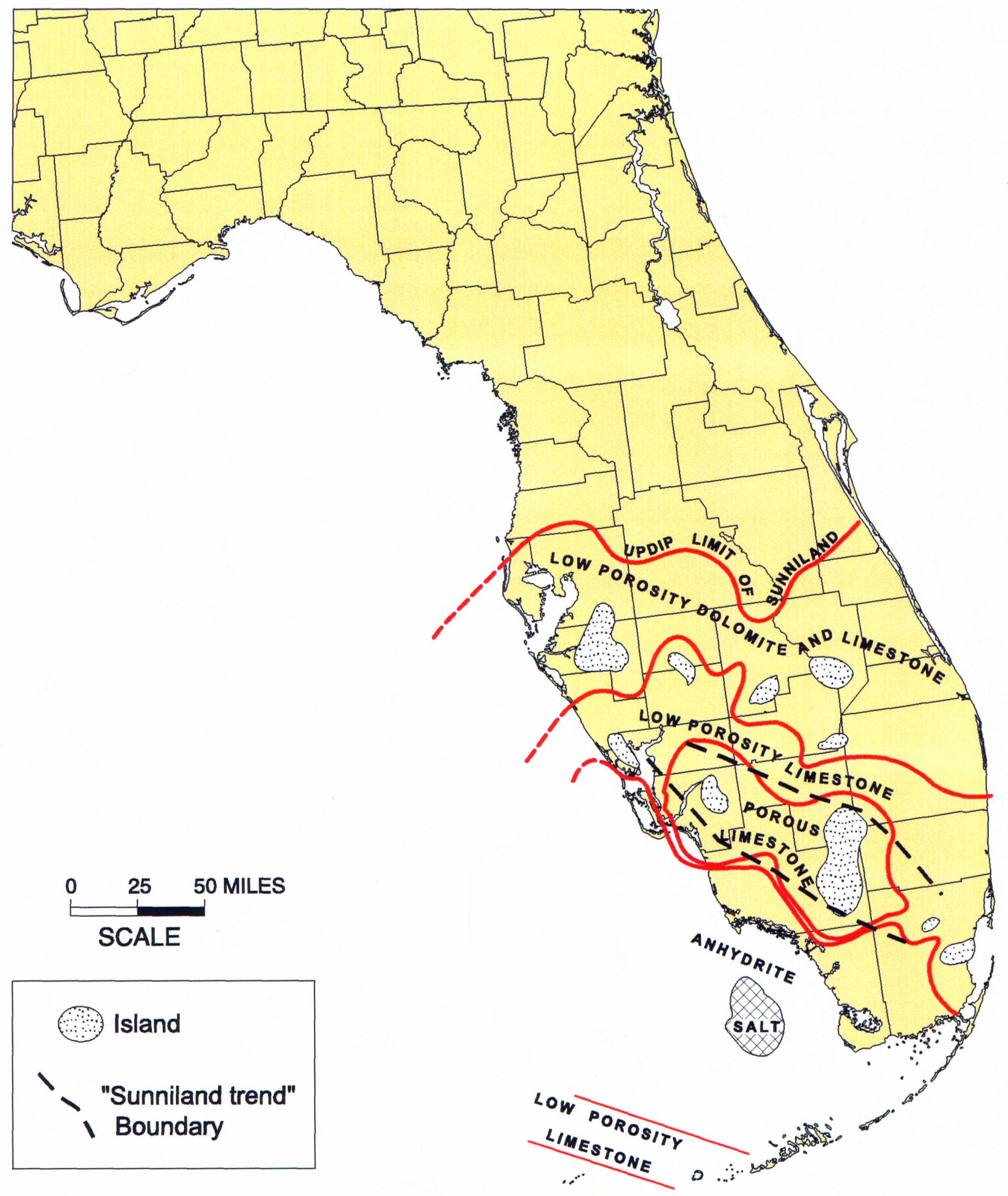

Figure 9.-- Map showing updip limit and distribution of carbonate and evaporite facies of Sunniland Limestone, South Florida basin, Florida Peninsula. Modified from MitchellTapping (1986). 


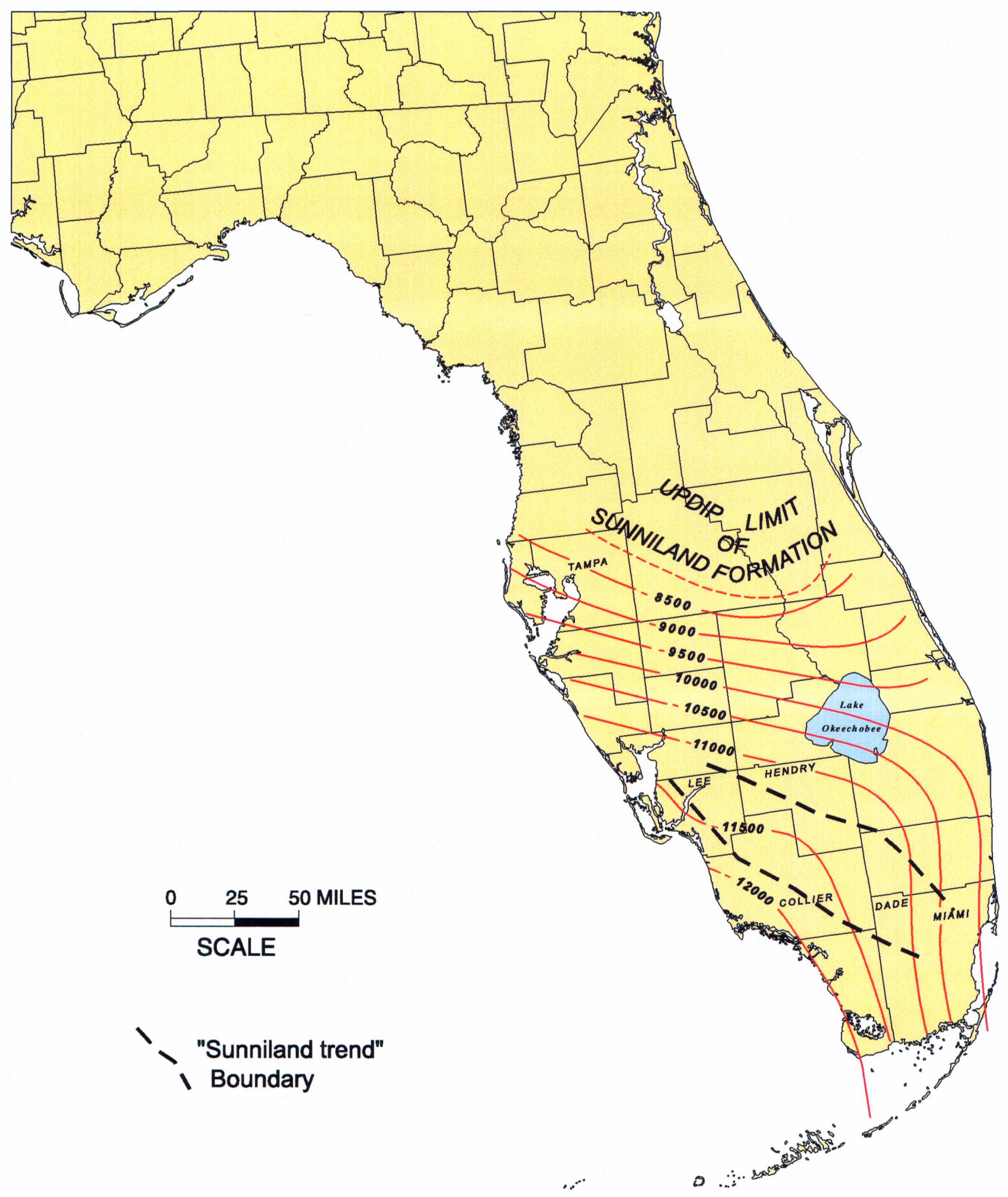

Figure 10. -- Structure contour map on top of Sunniland Formation, South Florida basin. Modified from Oglesby (1965). 


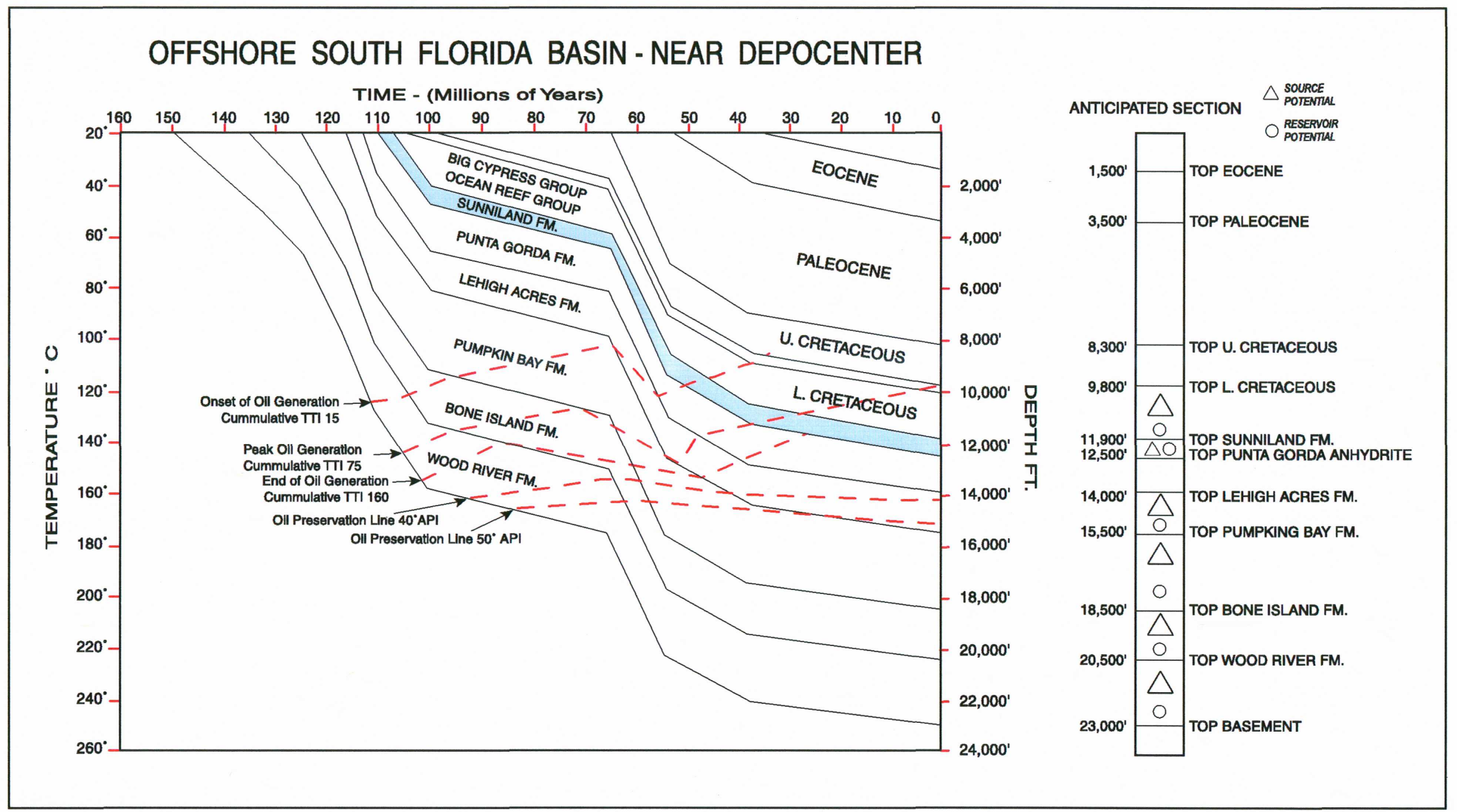

Figure 11. -- Burial history reconstructions and oil generation windows modeled of Late Jurassic through Eocene age rocks in the offshore near depocenter of South Florida basin in Florida Bay. Modified from Faulkner and Applegate (1986). 


\section{Petroleum Formation Profile Exxon - Collier 20-2 Well}

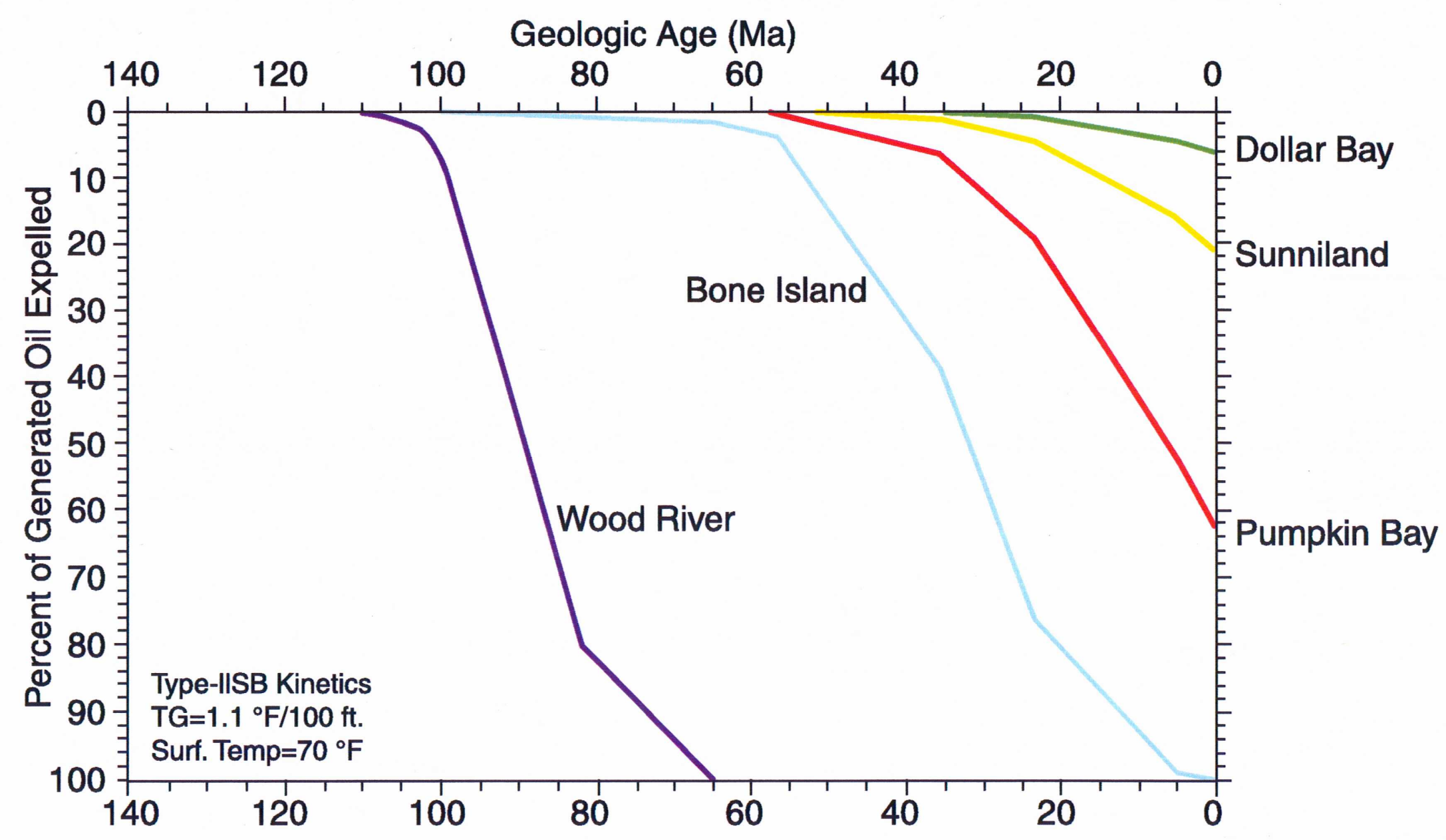

Figure 12. -- Calculated model for oil generation and expulsion for selected units in Exxon-Collier 20-2 well, Sunniland Field, Collier County, South Florida basin, Florida. IISB, oil type II, marine, algal sulfur model. TG, thermal gradient; Surf. Temp., mean annual surface temperature. 


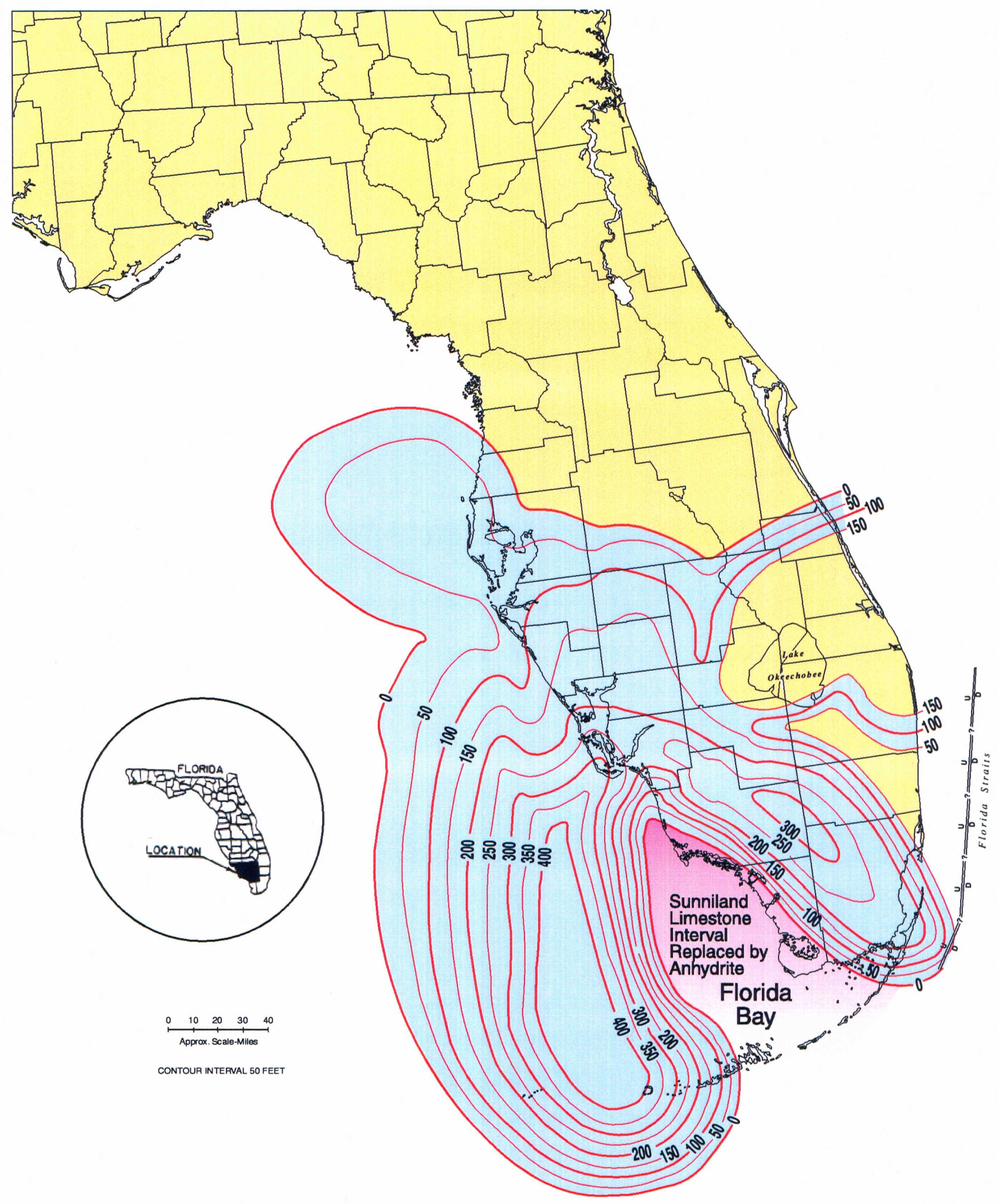

Figure 13. -- Isopach of Sunniland limestone thickness in South Florida basin. Note area to southwest in Florida Bay where limestone is replaced by anhydrite. Modified from Oglesby (1965). 


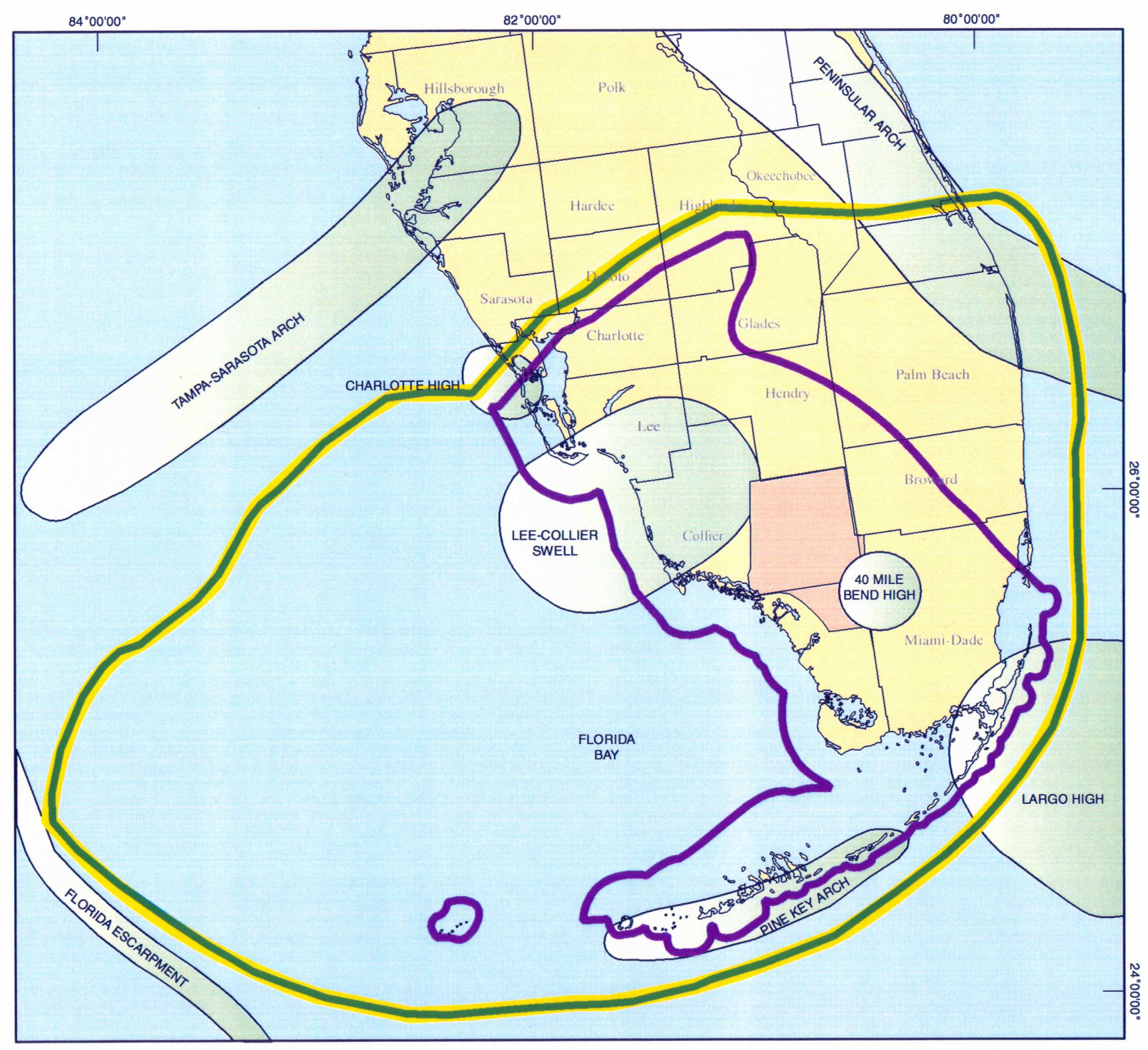

\section{South Florida Basin Pre-Punta Gorda TPS (505002)}

Pre-Punta Gorda Dolomite Gas and Oil Hypothetical Assessment Unit (50500201)

Legend:

-SFB Pre-Punta Gorda TPS

-Pod of Active Source Rock

- -Pre-Punta Gorda Dolomite Gas and Oil Hypothetical Assessment Unit -Structural Uplift

-Big Cypress National Preserve

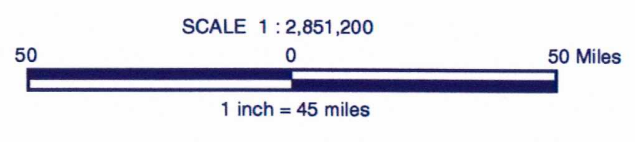

Figure 14. -- Map of South Florida basin showing boundaries of Pre-Punta Gorda Total Petroleum System (TPS) and Pre-Punta-Gorda Dolomite Gas and Oil Hypothetical Assessment Unit. 


\section{Total Petroleum System Events Chart}

Province Name: Florida Peninsula (50) TPS Name: $\begin{aligned} & \text { South Florida Basin } \\ & \text { Pre-Punta Gorda TPS (505002) }\end{aligned}$

Author(s): R.M. Pollastro/C.J. Schenk Date: 6/15/00

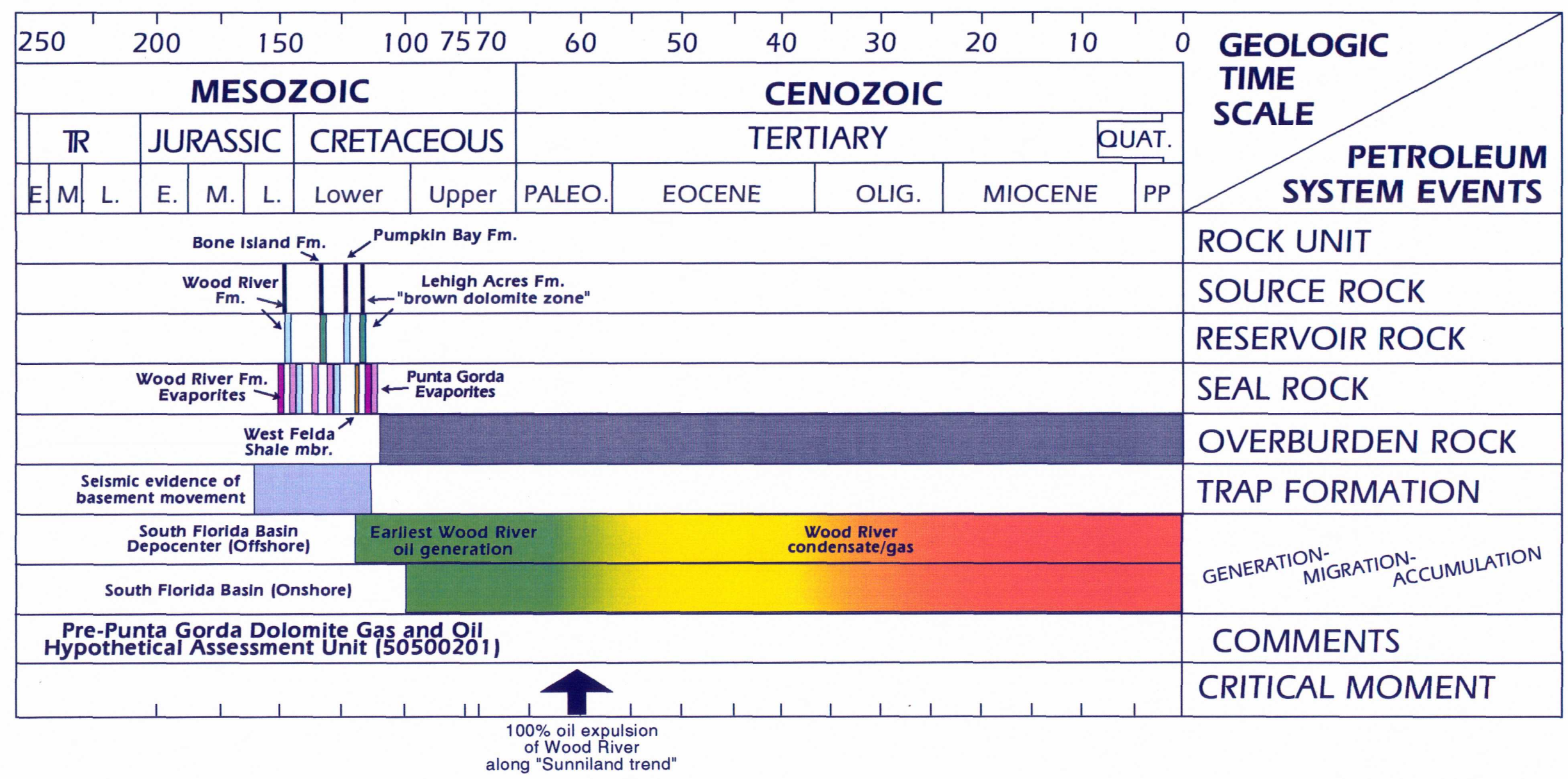

Figure 15.--Total Petroleum System (TPS) events chart for South Florida Basin Pre-Punta Gorda TPS and Pre-Punta Gorda Dolomite Gas and Oil Hypothetical Assessment Unit. 


\section{Lower Cretaceous Shoal-Reef Oil}

Assessment Unit 50500101

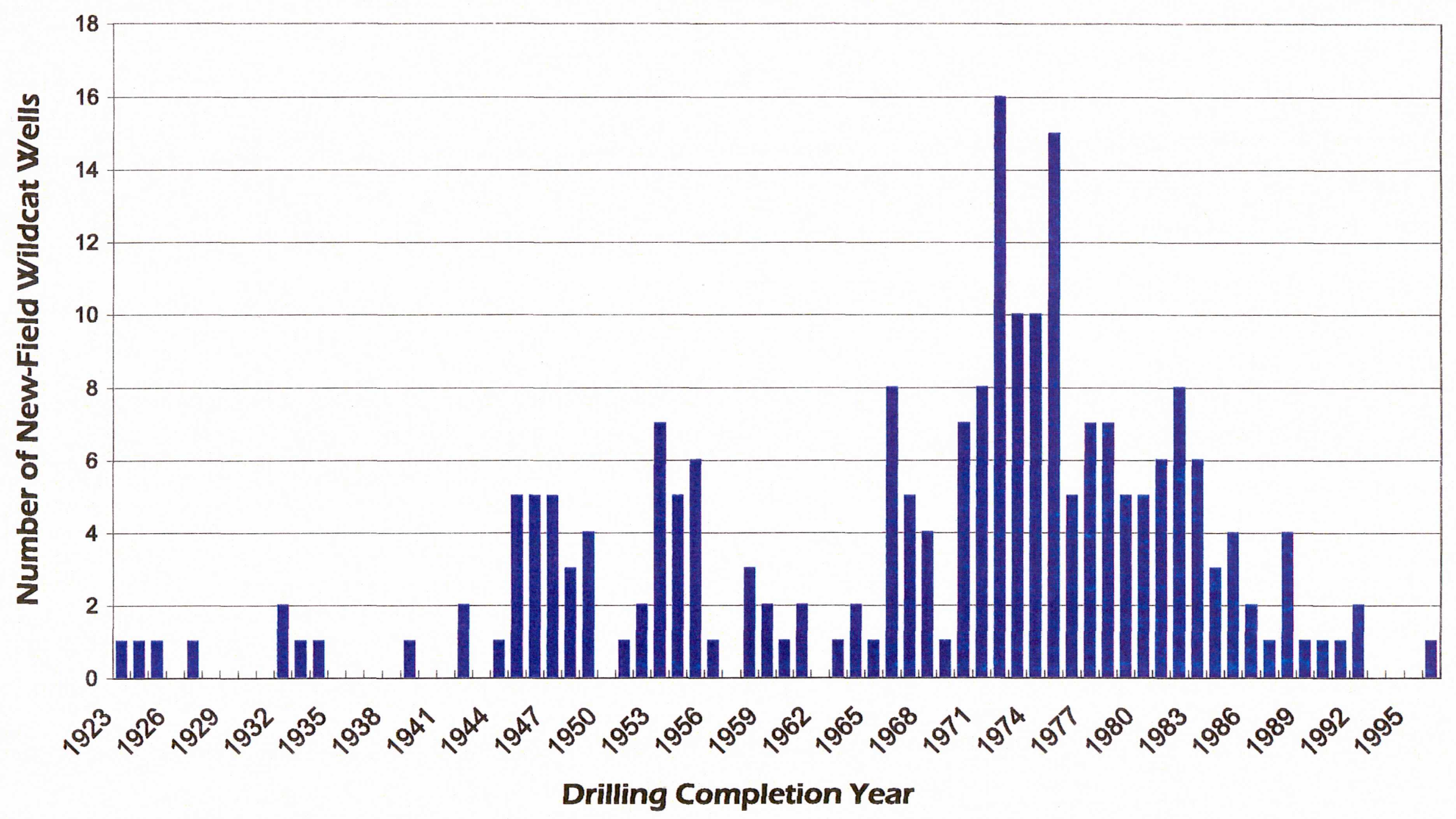

Figure 16. -- Plot of new-field wildcat wells versus drilling completion year for Lower Cretaceous Shoal-Reef Oil Assessment Unit, South Florida basin, Florida. 


\section{Lower Cretaceous Shoal-Reef Oil}

Assessment Unit 50500101

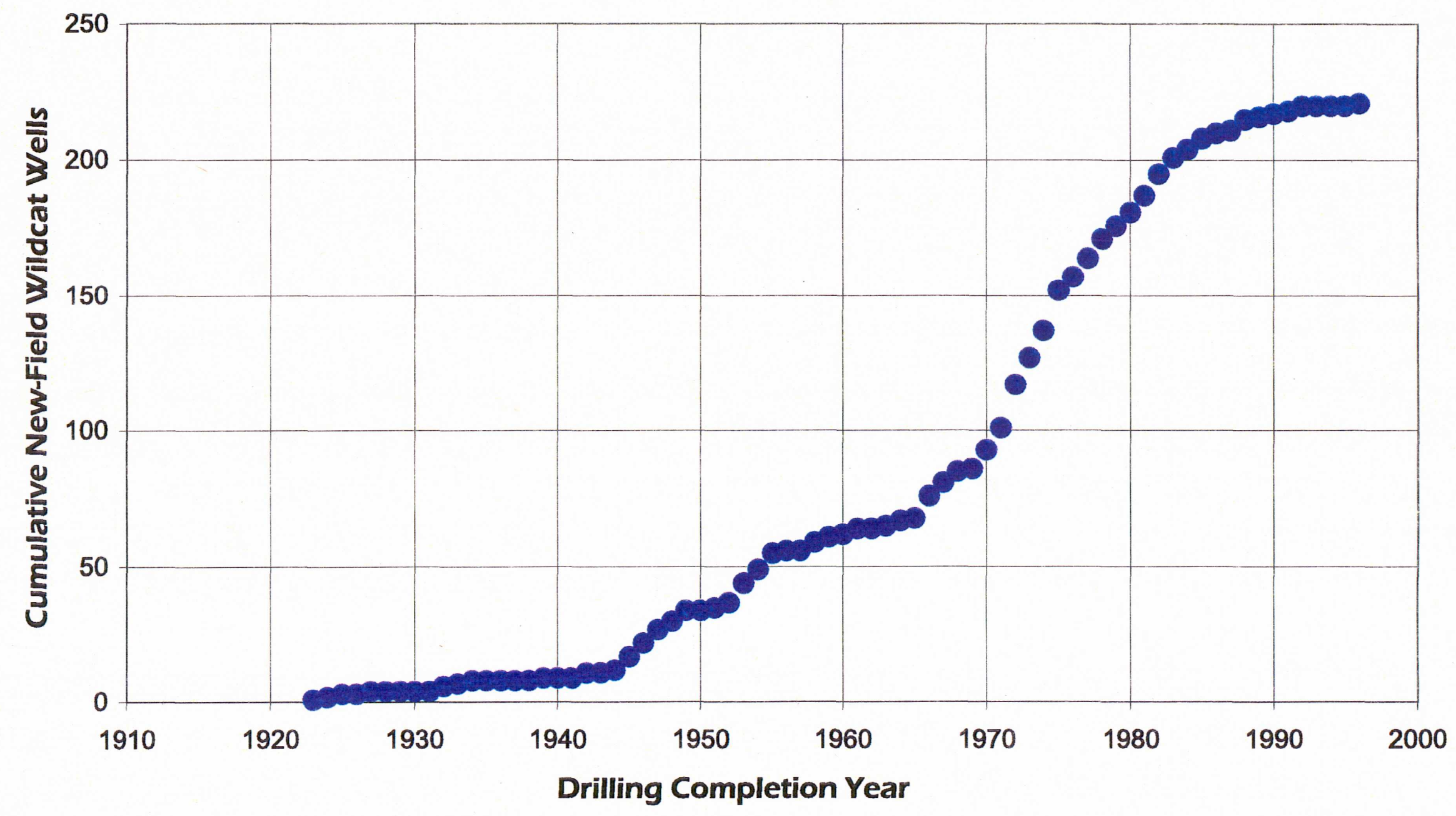

Figure 17. -- Plot of cumulative new-field wildcat wells versus drilling completion year for Lower Cretaceous Shoal-Reef Oil Assessment Unit, South Florida basin, Florida. 


\section{Lower Cretaceous Shoal-Reef Oil}

Assessment Unit 50500101

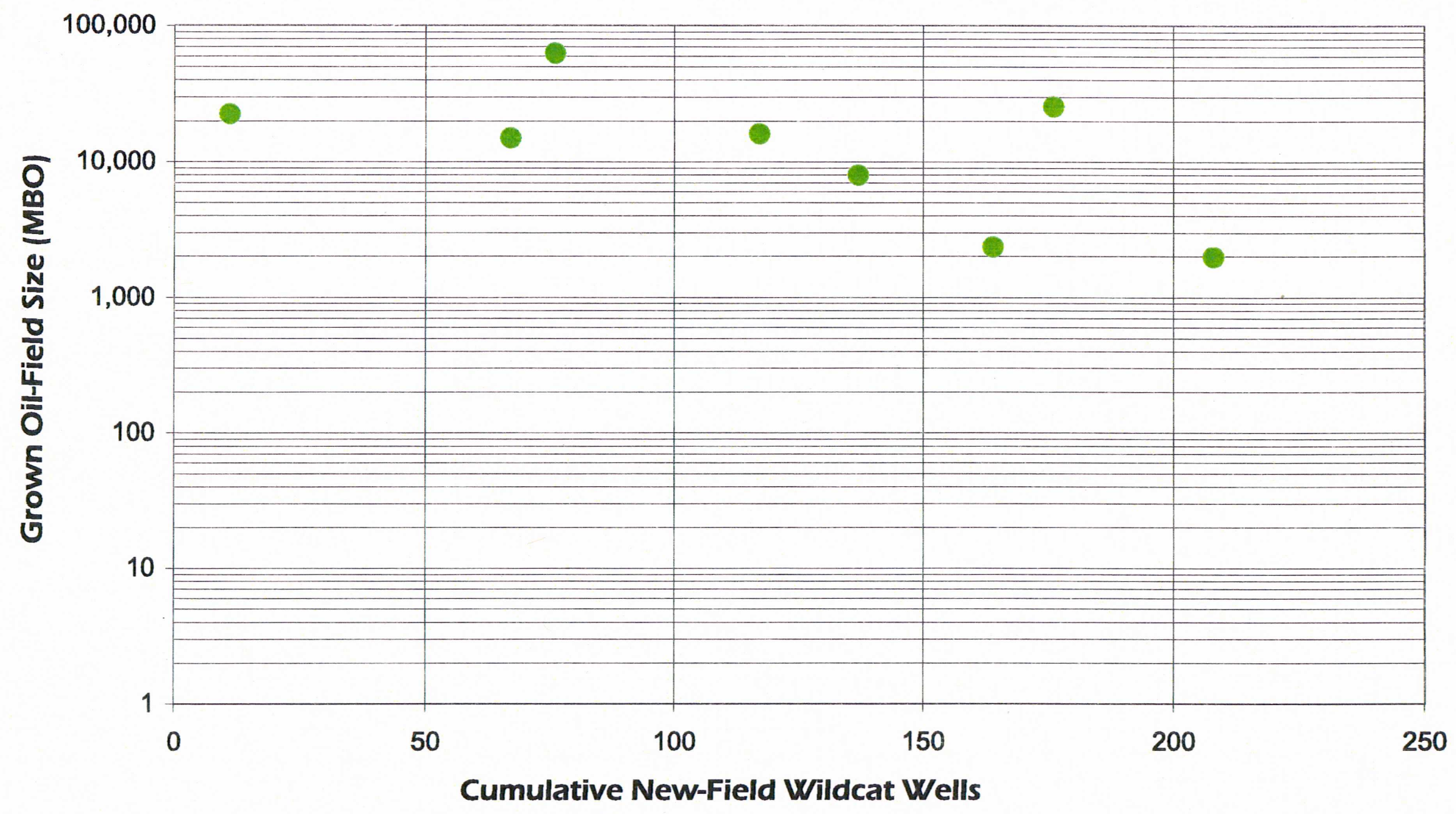

Figure 18. -- Plot of grown oil-field size versus cumulative new-field wildcat wells for Lower Cretaceous Shoal-Reef Oil Assessment Unit, South Florida basin, Florida. 


\section{Lower Cretaceous Shoal-Reef Oil}

Assessment Unit 50500101

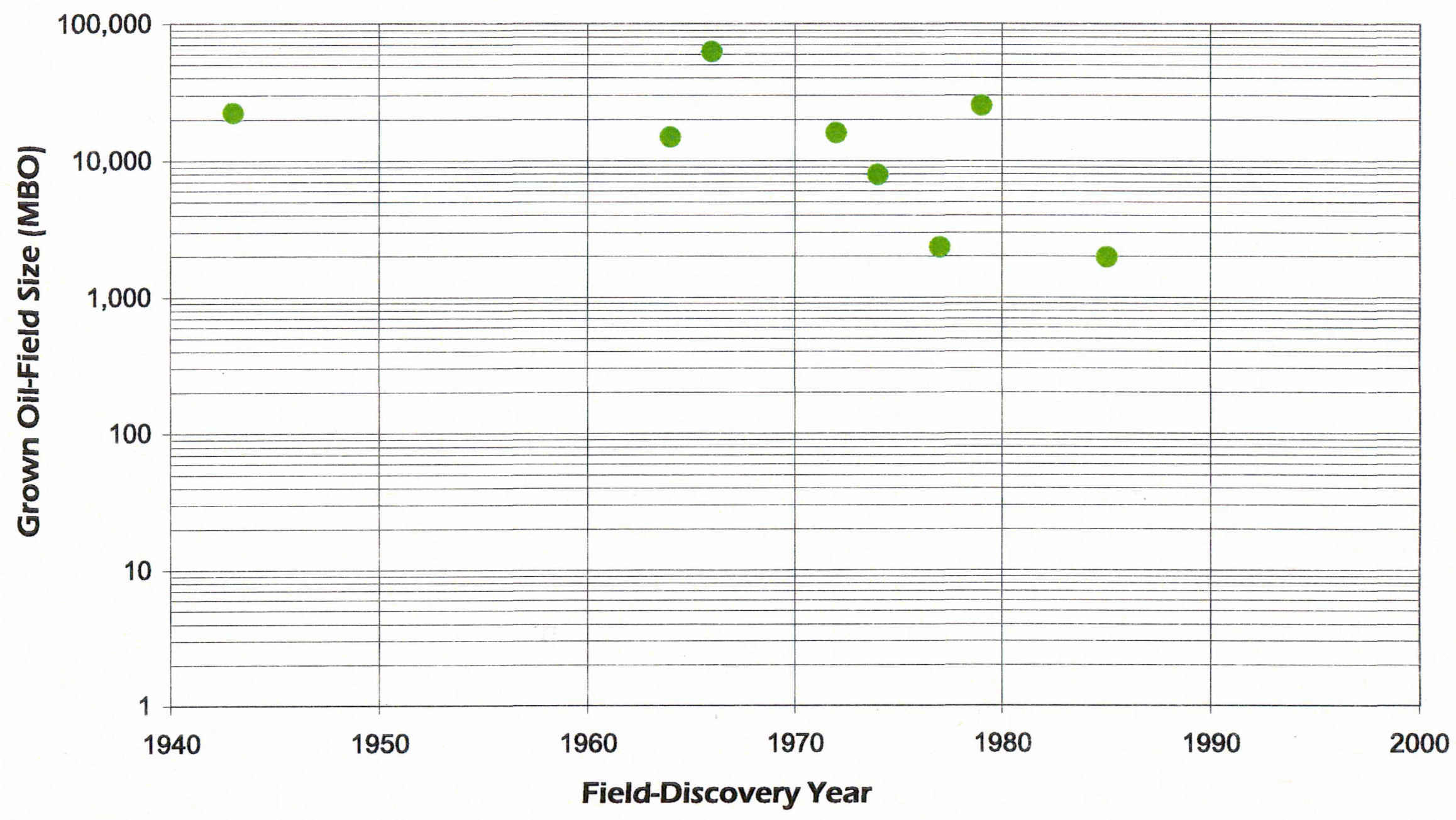

Figure 19. -- Plot of grown oil-field size versus field-discovery year for Lower Cretaceous Shoal-Reef Oil Assessment Unit, South Florida basin, Florida. 


\section{Lower Cretaceous Shoal-Reef Oil}

Assessment Unit 50500101

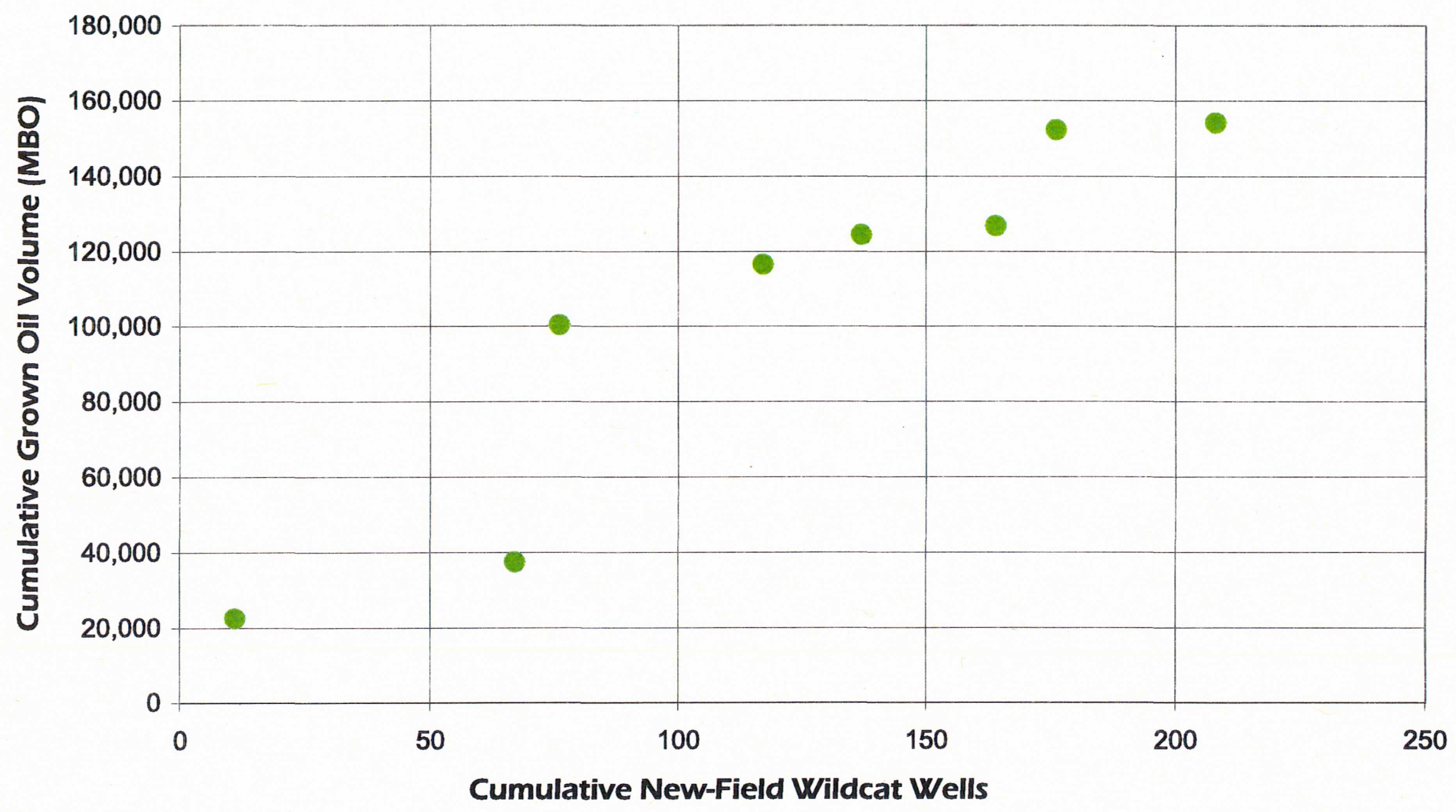

Figure 20. -- Plot of cumulative grown oil volume versus new-field wildcats for Lower Cretaceous Shoal-Reef Oil Assessment Unit, South Florida basin, Florida. 


\section{Lower Cretaceous Shoal-Reef Oil}

\section{Assessment Unit 50500101}

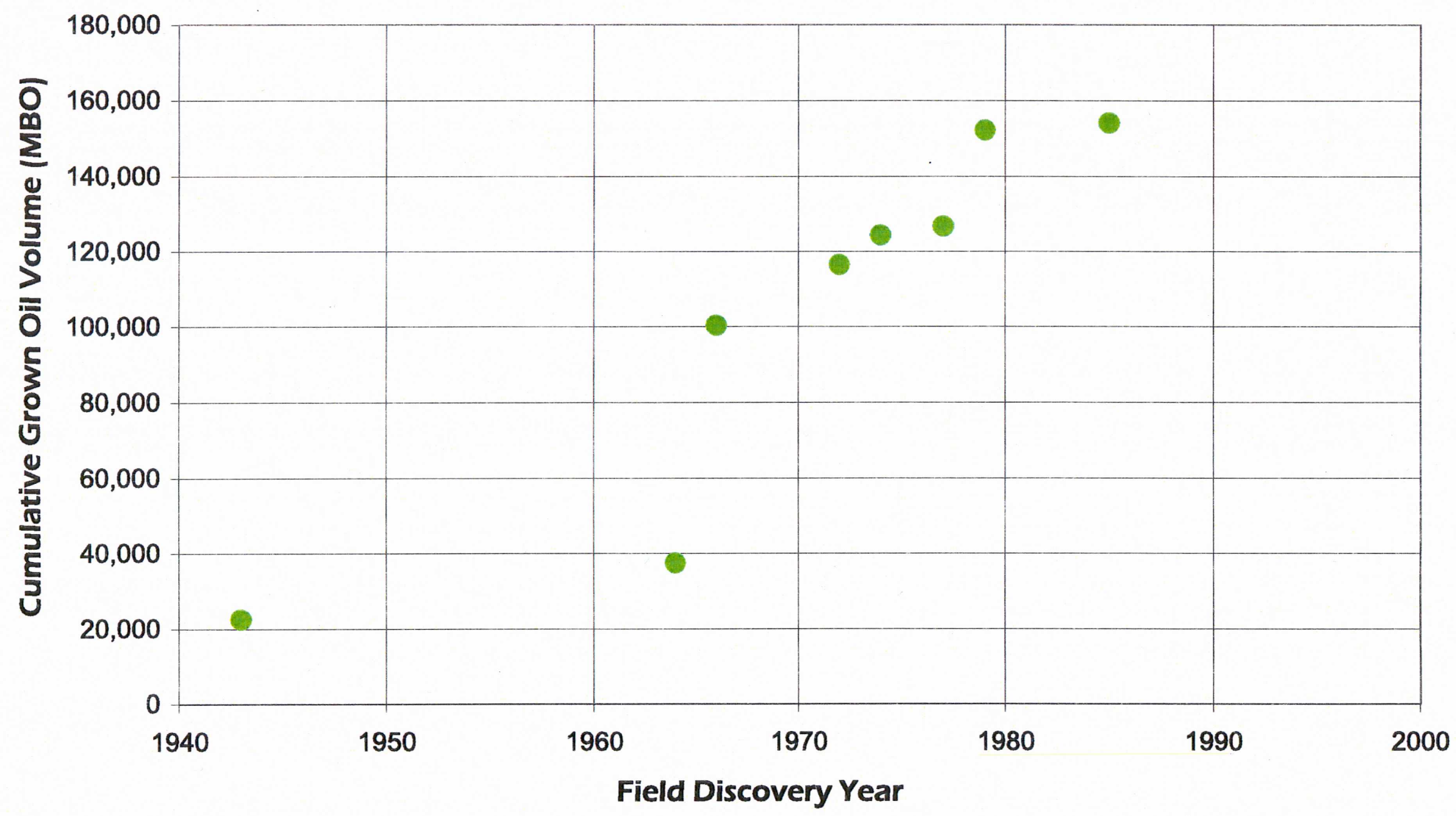

Figure 21. -- Plot of cumulative grown oil-field volume versus field-discovery year for Lower Cretaceous Shoal-Reef Oil Assessment Unit, South Florida basin, Florida. 
Table 1. -- Cumulative (CUM) oil and gas produced from active South Florida Sunniland fields through 1997. MBO, thousand barrels of oil; MMCFG, million cubic feet of gas. Data from Oil and Gas Section, Florida Geological Survey.

\begin{tabular}{|c|rr|}
\hline $\begin{array}{c}\text { SOUTH FLORIDA } \\
\text { SUNNILAND FIELDS }\end{array}$ & $\begin{array}{c}\text { CUM OIL } \\
\text { (MBO) }\end{array}$ & $\begin{array}{c}\text { CUM GAS } \\
\text { (MMCFG) }\end{array}$ \\
\hline Sunniland & 18,447 & 1,825 \\
Sunoco Felda & 11,598 & 982 \\
West Felda & 44,163 & 3,474 \\
Lake Trafford & 280 & 0 \\
\hline Bear Island & 11,622 & 969 \\
Lehigh Park & 5,568 & 571 \\
Mid-Felda & 1,513 & 10 \\
Racoon Point & 11,610 & 1,430 \\
\hline Townsend Canal & 535 & 0 \\
Corkscrew & 1,065 & 0 \\
\hline Total & 106,401 & 9,261 \\
\hline
\end{tabular}


Table 2.-- Assessment summary of undiscovered oil and gas from the Monte Carlo Simulation in South Florida basin, Florida, USGS Province 50, Florida Peninsula, from USGS Total Petroleum System (TPS)-Assessment Unit (AU) analysis. (MMBOE, million barrels of oil equivalent.. For this assessment, 6,000 cubic feet of gas equals 1 barrel of oil equivalent (BOE); MMBO, million barrels of oil; BCFG, billion cubic feet of gas; MMBNGL, million barrels of natural gas liquids)

\section{South Florida basin (USGS Province 50--Florida Peninsula Province)}

\begin{tabular}{lcccc}
\hline \multicolumn{4}{l}{ Sunniland/Dollar Bay TPS (500101) } & Lower Cretaceous Shoal-Reef Oil AU (50010101) \\
\hline & Mean & F95 & F50 & F5 \\
\hline Oil in Oil Fields (MMBO) & 272.54 & 43.22 & 238.94 & 615.03 \\
Gas in Oil Fields (BCFG) & 28.78 & 4.05 & 23.36 & 72.43 \\
NGL in Oil Fields (MMBNGL) & 1.72 & 0.23 & 1.36 & 4.52 \\
\hline AU SUBTOTAL (MMBOE) & $(279.06)$ & & & \\
\hline
\end{tabular}

Pre-Punta Gorda TPS (500102) -Pre-Punta Gorda Dolomite Gas and Oil Hypothetical AU (50010201)

\begin{tabular}{lrrrr}
\hline & Mean & F95 & F50 & \multicolumn{1}{c}{ F5 } \\
Oil in Oil Fields (MMBO) & 78.69 & 0.00 & 57.50 & 231.16 \\
Gas in Oil Fields (BCFG) & 83.78 & 0.00 & 56.30 & 259.78 \\
NGL in Oil Fields (MMBNGL) & 4.99 & 0.00 & 3.27 & 15.94 \\
Gas in Gas Fields (BCFG) & $1,545.41$ & 0.00 & $1,288.97$ & $3,951.48$ \\
NGL in Gas Fields (MMBNGL) & 68.01 & 0.00 & 54.77 & 181.55 \\
\hline AU SUBTOTAL (MMBOE) & $(423.14)$ & & & \\
\hline
\end{tabular}


Table 3.-- Comparison of assessment results for the 1995 USGS National Oil and Gas Assessment using play analysis (Pollastro, 1995) to the present total petroleum system-assessment unit (TPS-AU) study of the South Florida basin, Florida. (MMBOE, million barrels of oil equivalent. For this assessment, 6,000 cubic feet of gas equals 1 barrel of oil equivalent (BOE); MMBO, million barrels of oil; BCFG, billion cubic feet of gas; MMBNGL, million barrels of natural gas liquids). Resources are rounded to nearest whole number.

\section{Play-Based Assessment}

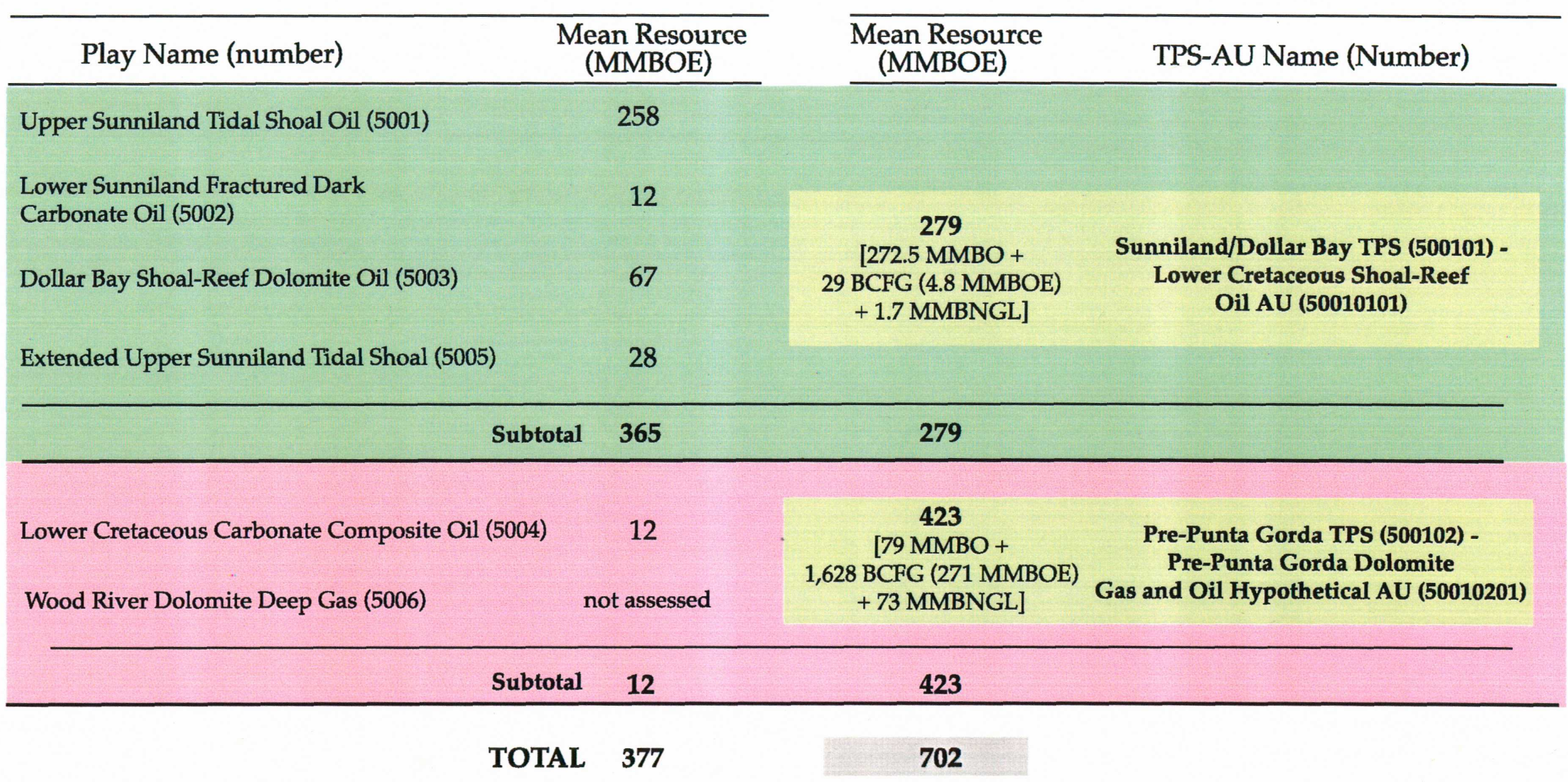

\section{TPS-AU Assessment} Lower Cretaceous Shoal-Reef Oil AU (50010101) 
Table 4.-- Assessment of undiscovered oil and gas from the Monte Carlo Simulation in the Big Cypress National Preserve, South Florida basin, Florida from USGS Total Petroleum System (TPS)-Assessment Unit (AU) analysis. (MMBOE, million barrels of oil equivalent; $\mathrm{MMBO}$, million barrels of oil; BCFG, billion cubic feet of gas; MMBNGL, million barrels of natural gas liquids)

\section{Big Cypress National Preserve, Florida}

Sunniland/Dollar Bay TPS (500101) - Lower Cretaceous Shoal-Reef Oil AU (50010101)

\begin{tabular}{lcccc}
\hline & Mean & F95 & F50 & F5 \\
\hline Oil in Oil Fields (MMBO) & 24.01 & 3.67 & 20.60 & 56.18 \\
Gas in Oil Fields (BCFG) & 2.54 & 0.34 & 2.02 & 6.53 \\
NGL in Oil Fields (MMBNGL) & 0.15 & 0.02 & 0.12 & 0.40 \\
\hline AU SUBTOTAL (MMBOE) & $(24.58)$ & & &
\end{tabular}

Pre-Punta Gorda TPS (500102) -Pre-Punta Gorda Dolomite Gas and Oil Hypothetical AU (50010201)

\begin{tabular}{lrrrr}
\hline & Mean & F95 & F50 & \multicolumn{1}{c}{ F5 } \\
Oil in Oil Fields (MMBO) & 3.94 & 0.00 & 2.75 & 12.01 \\
Gas in Oil Fields (BCFG) & 4.17 & 0.00 & 2.69 & 13.44 \\
NGL in Oil Fields (MMBNGL) & 0.25 & 0.00 & 0.16 & 0.82 \\
Gas in Gas Fields (BCFG) & 185.41 & 0.00 & 153.54 & 480.39 \\
NGL in Gas Fields (MMBNGL) & 8.16 & 0.00 & 6.52 & 21.94 \\
\hline AU SUBTOTAL (MMBOE) & $(43.95)$ & & & \\
\hline MEAN TOTAL UNDISCOVERED & $(68.53)$ & & & \\
RESOURCE (MMBOE) & $(\mathbf{6})$ & & \\
\hline
\end{tabular}




\section{SEVENTH APPROXIMATION \\ NATIONAL ASSESSMENT OF OIL AND GAS RESOURCES \\ DATA FORM FOR CONVENTIONAL ASSESSMENT UNITS}

Date:

Assessment Geologist:

Region:

Province:

Total Petroleum System:......

Assessment Unit:

* Notes from Assessor
$5 / 22 / 00$

C.J. Schenk and R.M. Pollastro

\begin{tabular}{l} 
North America \\
\hline Florida Peninsula \\
\hline Louth Florida Basin Sunniland/Dollar Bay \\
\hline Lower 48 Growth Function
\end{tabular}

Number: 5

Numbe:: 5050

Number: 505001

Number: 50500101

\section{CHARACTERISTICS OF ASSESSMENT UNIT}

Oil ( $<20,000 \mathrm{cfg} / \mathrm{bo}$ overall) or Gas $(\geq 20,000 \mathrm{cfg} / \mathrm{bo}$ overall) $\ldots$

Oil

What is the minimum field size?........ $0.5 \quad$ mmboe grown ( $\geq 1 \mathrm{mmboe}$ )

(the smallest field that has potential to be added to reserves in the next 30 years)

Number of discovered fields exceeding minimum size:...........

Established ( $>13$ fields)

Frontier ( $1-13$ fields $)$

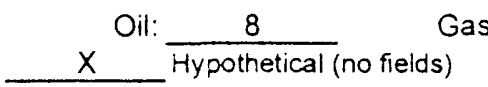
19 1st half

1st 3rd 2nd half 5.1

2nd 3rd

3 rd 3rd

\section{Assessment-Unit Probabilities:}

Attribute

1. CHARGE: Adequate petroleum charge for an undiscovered field $\geq$ minimum size...............

2. ROCKS: Adequate reservoirs, traps, and seals for an undiscovered field $\geq$ minimum size......

3. TIMING OF GEOLOGIC EVENTS: Favorable timing for an undiscovered field $\geq$ minimum size

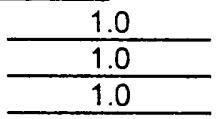

Assessment-Unit GEOLOGIC Probability (Product of 1, 2, and 3):.....

4. ACCESSIBILITY: Adequate location to allow exploration for an undiscovered field $\geq$ minimum size.

\section{UNDISCOVERED FIELDS}

Number of Undiscovered Fields: How many undiscovered fields exist that are $\geq$ minimum size?: (uncertainty of fixed but unknown values)

Oil fields: $\min$. no. $(>0)$

Gas fields: min. no. $(>0)$

2 median no.

$\max$ no. $\max$ no. 75

Size of Undiscovered Fields: What are the anticipated sizes (grown) of the above fields?: (variations in the sizes of undiscovered fields)

Oil in oil fields (mmbo)

Gas in gas fields (bcfg): min. size

min. size

$\square_{\text {median size }}^{\text {median size }} \underset{-5}{ }$
max. size 
AVERAGE RATIOS FOR UNDISCOVERED FIELDS, TO ASSESS COPRODUCTS (uncertainty of fixed but unknown values)

Oil Fields:

Gas/oil ratio (cfg/bo)......

NGL/gas ratio (bngl/mmcfg)

Gas fields:

Liquids/gas ratio (bngl/mmcfg)

Oil/gas ratio (bo/mmcfg).

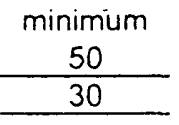

minimum

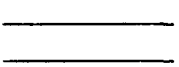

\begin{tabular}{c}
$\begin{array}{c}\text { median } \\
100\end{array}$ \\
\hline 60 \\
\hline
\end{tabular}

median

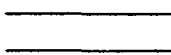

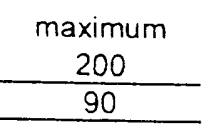

maximum

\section{SELECTED ANCILLARY DATA FOR UNDISCOVERED FIELDS}

(variations in the properties of undiscovered fields)

Qil Fields:

API gravity (degrees).

Sulfur content of oil (\%).

Drilling Depth $(m)$

Depth $(m)$ of water (if applicable)

\section{Gas Fieids:}

Inert gas content (\%)

$\mathrm{CO}$, content $(\%)$

Hydrogen-sulfide content $(\%)$

Drilling Depth $(m)$.

Depth $(m)$ of water (if applicable).

\begin{tabular}{c}
$\begin{array}{c}\text { minimum } \\
15\end{array}$ \\
\hline$\frac{0.5}{2500}$ \\
\hline 0 \\
\hline
\end{tabular}

minimum

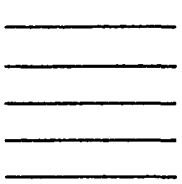

median

25

1.5

3500

30

median

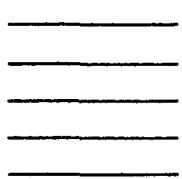

\begin{tabular}{c}
$\begin{array}{c}\text { maximum } \\
35\end{array}$ \\
\hline 4 \\
\hline 4500 \\
\hline 100 \\
\hline
\end{tabular}

maximum

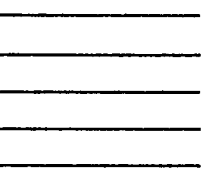




\section{ALLOCATION OF UNDISCOVERED RESOURCES IN THE ASSESSMENT UNIT TO COUNTRIES OR OTHER LAND PARCELS (uncertainty of fixed but unknown values)}

1. Big Cypress National Preserve

Qil in Qil Fields:

Richness factor (unitless multiplier):....

Volume \% in parcel (areal \% x richness factor).

Portion of volume $\%$ that is offshore $(0-100 \%)$

Gas in Gas Fields:

Richness factor (unitless multiplier):

Portion of volume $\%$ that is offshore $(0-100 \%)$

2. Florida

represents

\section{Qil in Qil Fields:}

Richness factor (unitless multiplier):

Volume \% in parcel (areal \% x richness factor):.

Portion of volume $\%$ that is offshore $(0-100 \%)$

Gas in Gas Fields:

Richness factor (unitless multiplier):

Volume $\%$ in parcel (areal $\% \times$ richness factor).

Portion of volume $\%$ that is offshore $(0-100 \%) . . .$.

3. Florida Peninsula, Province 50 represents

Qil in Oil Fields:

Richness factor (unitless multiplier):

Volume $\%$ in parcel (areal $\%$ x richness factor).

Portion of volume $\%$ that is 8 ffshore $(0-100 \%)$.....

\section{Gas in Gas Fields:}

Richness factor (unitless multiplier):

Volume $\%$ in parcel (areal $\% x$ richness factor)

Portion of volume $\%$ that is offshore $(0-100 \%) \ldots .$.

6 areal $\%$ of the total assessment unit

minimum

\begin{tabular}{c}
\hline 6 \\
\hline 0
\end{tabular}

minimum

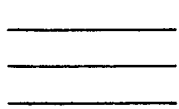

median

$\frac{9}{0}$

median

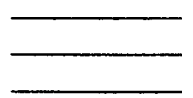

maximum

$\frac{12}{0}$

maximum

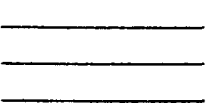

100 areal $\%$ of the total assessment unit

\begin{tabular}{c} 
minimum \\
\hline 100 \\
\hline 26 \\
\hline
\end{tabular}

minimum

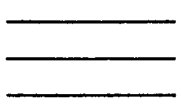

100 areal $\%$ of the total assessment unit

minimum

$\frac{100}{26}$

minimum median

$\frac{100}{30}$

median

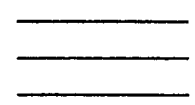

$$
\text { median }
$$

$\frac{100}{30}$

median maximum

$\frac{100}{34}$

maximum

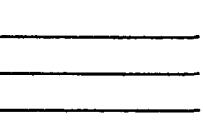

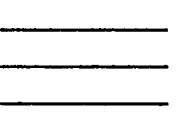

maximum

$\frac{100}{34}$

maximum

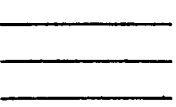




\section{SEVENTH APPROXIMATION \\ NEW MILLENNIUM WORLD PETROLEUM ASSESSMENT \\ DATA FORM FOR CONVENTIONAL ASSESSMENT UNITS}

Date

Assessment Geologist:........

Region:

Province:

Total Petroleum System:......

Assessment Unit:..............

* Notes from Assessor
$5 / 22 / 00$

C.J. Schenk and R.M. Pollastro

North America

Florida Peninsula

South Florida Basin Pre-Punta Gorda

Pre-Punta Gorda Dolomite Gas and Oil Hypothetical

Plays 4910 and 4912 as analogs
Number: 5

Number: 5050

Number: 505002

Number: 50500201

\section{CHARACTERISTICS OF ASSESSMENT UNIT}

Oil $(<20,000 \mathrm{cfg} /$ bo overall) or Gas $(\geq 20,000 \mathrm{cfg} / \mathrm{bo}$ overall $) \ldots \ldots$ Gas

What is the minimum field size?........ $\quad 0.5 \quad$ mmboe grown ( $\geq 1 \mathrm{mmboe}$ )

(the smallest field that has potential to be added to reserves in the next 30 years)

Number of discovered fields exceeding minimum size:.......... Established ( $>13$ fields)

Oil: $\frac{0}{\text { Hypothetical (no fields) }}$ $\frac{0}{x}$

Median size (grown) of discovered oil fields (mmboe):

Median size (grown) of discovered gas fields (bcfg):

1 st 3rd

2nd 3rd

3rd 3rd

1st 3rd

2nd 3rd

3rd 3rd

Assessment-Unit Probabilities:

Attribute

Probability of occurrence $(0-1,0)$

1. CHARGE: Adequate petroleum charge for an undiscovered field $\geq$ minimum size....

2. ROCKS: Adequate reservoirs, traps, and seals for an undiscovered field $\geq$ minimum size.......

3. TIMING OF GEOLOGIC EVENTS: Favorable timing for an undiscovered field $\geq$ minimum size

\begin{tabular}{c}
0.9 \\
\hline 1.0 \\
\hline 1.0 \\
\hline
\end{tabular}

Assessment-Unit GEOLOGIC Probability (Product of 1, 2, and 3):

4. ACCESSIBILITY: Adequate location to allow exploration for an undiscovered field $\geq$ minimum size.

\section{UNDISCOVERED FIELDS}

Number of Undiscovered Fields: How many undiscovered fields exist that are $\geq$ minimum size?: (uncertainty of fixed but unknown values)

Oil fields: . min. no. $(>0)$

Gas fields: min. no. $(>0)$

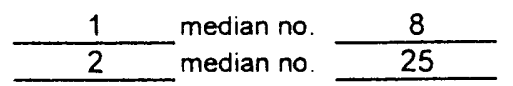

$\max n$ no. $\frac{24}{75}$

Size of Undiscovered Fields: What are the anticipated sizes (grown) of the above fields?:

(variations in the sizes of undiscovered fields)

Oil in oil fields (mmbo)

Gas in gas fields (bcfg): min. size

min. size

$\frac{0.5}{3}$ median size $\frac{4}{24}$

max. size $\max$ size
300

2000 
Assessment Unit (name, no.)

AVERAGE RATIOS FOR UNDISCOVERED FIELDS, TO ASSESS COPRODUCTS (uncertainty of fixed but unknown values)

Qil Fields:

minimum

Gas/oil ratio (cfg/bo).....

NGLgas ratio (bngl/mmcf $f_{g}$ )

Gas fields:

Liquids/gas ratio (bnglimmcfg)

Oil/gas ratio (bo/mmcfg)

\begin{tabular}{c}
500 \\
\hline 30 \\
minimum \\
22 \\
\hline \\
\hline
\end{tabular}

\begin{tabular}{c}
$\begin{array}{c}\text { median } \\
1000\end{array}$ \\
\hline 60 \\
\hline
\end{tabular}

median

44

$\longrightarrow$

\begin{tabular}{c}
$\begin{array}{c}\text { maximum } \\
2000\end{array}$ \\
\hline 90 \\
\hline
\end{tabular}

maximum

66

\section{SELECTED ANCILLARY DATA FOR UNDISCOVERED FIELDS}

(variations in the properties of undiscovered fields)

Qil Fields: minimum

API gravity (degrees)

Sulfur content of oil (\%)

Drilling Depth $(m)$

Depth $(m)$ of water (if applicable).

$\frac{\frac{20}{0.5}}{\frac{3200}{0}}$

\begin{tabular}{c}
$\begin{array}{c}\text { median } \\
35\end{array}$ \\
\hline$\frac{1.5}{4200}$ \\
\hline 30
\end{tabular}

\begin{tabular}{c}
$\begin{array}{c}\text { maximum } \\
50\end{array}$ \\
\hline 4 \\
\hline 5200 \\
\hline 100 \\
\hline
\end{tabular}

Gas Fields:

minimum

median

maximum

Inert gas content (\%).

$\frac{}{-}$

\section{$\longrightarrow$} 6500

100 


\section{ALLOCATION OF UNDISCOVERED RESOURCES IN THE ASSESSMENT UNIT TO COUNTRIES OR OTHER LAND PARCELS (uncertainty of fixed but unknown values)}

8

minimum

Qil in Qil Fields:

Richness factor (unitless multiplier):...

Volume $\%$ in parcel (areal $\%$ x richness factor) :...

Portion of volume $\%$ that is offshore $(0-100 \%) \ldots$.

Gas in Gas Fields:

Richness factor (unitless multiplier):...

Volume \% in parcel (areal \% $x$ richness factor)

Portion of volume $\%$ that is offshore $(0-100 \%) \ldots$.

2. Florida

represents

Qil in Oil Fieids:

Richness factor (unitless multiplier):.

Volume \% in parcel (areal \% x richness factor)....

Portion of volume $\%$ that is offshore $(0-100 \%)$

Gas in Gas Fields:

Richness factor (unitless multiplier):

Volume $\%$ in parcel (areal $\%$ x richness factor).

Portion of volume $\%$ that is offshore $(0-100 \%) \ldots \ldots$.

3. Florida Peninsula, Province 50

represents

\section{Qil in Qil Fields:}

Richness factor (unitless multiplier):...

Volume $\%$ in parcel (areal $\% \times$ richness factor):...

Portion of volume $\%$ that is offshore $(0-100 \%) \ldots .$.

Gas in Gas Fields:

Richness factor (unitless multiplier):

Volume \% in parcel (areal \% x richness factor)

Portion of volume $\%$ that is offshore $(0-100 \%) \ldots .$.

$\frac{2}{0}$

minimum

$\begin{array}{r}\hline 9 \\ \hline 0 \\ \hline\end{array}$

minimum

$\frac{100}{33}$

minimum

$\frac{100}{33}$

100

$\frac{\frac{\text { minimum }}{100}}{\frac{33}{\text { minimum }}}$

areal $\%$ of the total assessment unit

median

maximum

$\frac{5}{0}$

$\frac{8}{0}$

median

maximum

$\frac{12}{0}$

$\frac{15}{0}$
areal $\%$ of the total assessment unit

median

maximum

$\frac{100}{36}$

$\frac{100}{39}$

median

maximum

$\frac{100}{36}$

$\frac{100}{39}$
areal $\%$ of the total assessment unit

median

$\frac{100}{36}$

median

$\frac{100}{36}$

maximum

$\frac{100}{39}$

maximum

100




\author{
Appendix C \\ Monte Carlo Output \\ For Assessment Unit 50500101 \\ Lower Cretaceous Shoal-Reef Oil
}

Contained in this appendix are detailed descriptions of the probability distributions of the results of the assessment of AU 50500101, the Lower Cretaceous Shoal-Reef Oil Assessment Unit. These details may be of use to those pursuing further analysis of the results. The first four distributions (pages $\mathrm{C} 2$ to $\mathrm{C} 9$ ) describe the results for the entire assessment unit. The next three (pages $\mathrm{C} 10$ to $\mathrm{C} 15$ ) describe the results allocated to Big Cypress National Preserve. Each distribution is documented by two pages. On the first page are the distribution parameters, most importantly the mean, as well as a graph of the probability density function. The second page lists the percentiles (fractiles) of the distribution at $5 \%$ intervals.

Also included in Appendix C (pages C16 to C19) are the descriptions of probability distributions of the input based on the input parameters documented in Appendix A. Each of the distributions used in calculating the results is documented by its parameters and a graph of the probability density function. Note that for the distribution of size of undiscovered oil fields (pages $\mathrm{C} 16$ and $\mathrm{C} 17$ ), the parameters of both the shifted and unshifted lognormal distributions are given. The accompanying graph is that of the unshifted distribution. 
50500101

Lower Cretaceous Shoal-Reef Oil

Monte Carlo Results

\section{Forecast: Oil in Undiscovered Oil Fields}

Summary:

Display range is from 0.00 to $800.00 \mathrm{MMBO}$

Entire range is from 3.36 to $1,143.91 \mathrm{MMBO}$

After 50,000 trials, the standard error of the mean is 0.81

Statistics:

Trials

Value

Mean

50000

Median

272.54

Mode

238.94

Standard Deviation

180.93

Variance

$32,734.41$

Skewness

0.78

Kurtosis

3.13

Coefficient of Variability

0.66

Range Minimum

3.36

Range Maximum

$1,143.91$

Range Width

$1,140.55$

Mean Standard Error

0.81

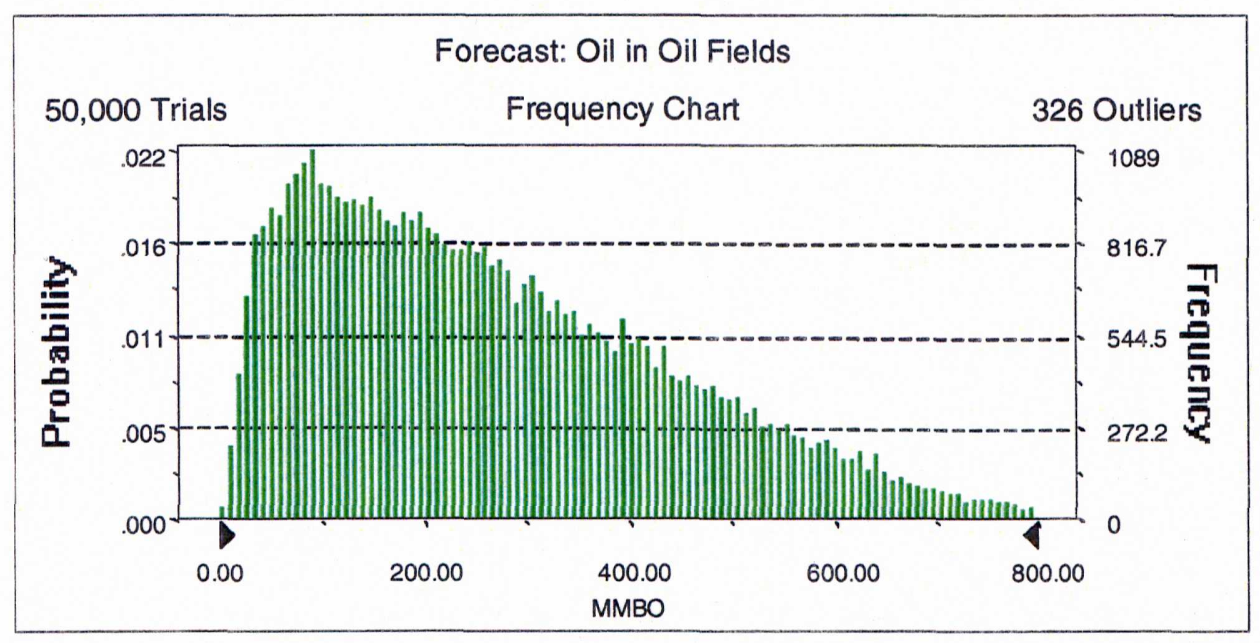


50500101

Lower Cretaceous Shoal-Reef Oil

Monte Carlo Results

Forecast: Oil in Undiscovered Oil Fields (cont'd)

Percentiles:

\begin{tabular}{rr} 
Percentile & MMBO \\
\hline $100 \%$ & 3.36 \\
$95 \%$ & 43.22 \\
$90 \%$ & 65.14 \\
$85 \%$ & 84.89 \\
$80 \%$ & 104.04 \\
$75 \%$ & 125.05 \\
$70 \%$ & 146.28 \\
$65 \%$ & 168.20 \\
$60 \%$ & 191.06 \\
$55 \%$ & 213.83 \\
$50 \%$ & 238.94 \\
$45 \%$ & 263.99 \\
$40 \%$ & 291.61 \\
$35 \%$ & 320.88 \\
$30 \%$ & 353.73 \\
$25 \%$ & 390.37 \\
$20 \%$ & 428.25 \\
$15 \%$ & 474.42 \\
$10 \%$ & 532.37 \\
$5 \%$ & 615.03 \\
$0 \%$ & 1.143 .91
\end{tabular}

End of Forecast 
50500101

Lower Cretaceous Shoal-Reef Oil

Monte Carlo Results

\section{Forecast: Gas in Undiscovered Oil Fields}

$\begin{array}{lr}\text { Summary: } \\ \text { Display range is from } 0.00 \text { to } 90.00 \mathrm{BCFG} \\ \text { Entire range is from } 0.30 \text { to } 174.06 \mathrm{BCFG} \\ \text { After } 50,000 \text { trials, the standard error of the mean is } 0.10 \\ \text { Statistics: } & \underline{\text { Value }} \\ \text { Trials } & 50000 \\ \text { Mean } & 28.78 \\ \text { Median } & 23.36 \\ \text { Mode } & -- \\ \text { Standard Deviation } & 22.05 \\ \text { Variance } & 486.35 \\ \text { Skewness } & 1.36 \\ \text { Kurtosis } & 5.30 \\ \text { Coefficient of Variability } & 0.77 \\ \text { Range Minimum } & 0.30 \\ \text { Range Maximum } & 174.06 \\ \text { Range Width } & 173.76 \\ \text { Mean Standard Error } & 0.10\end{array}$

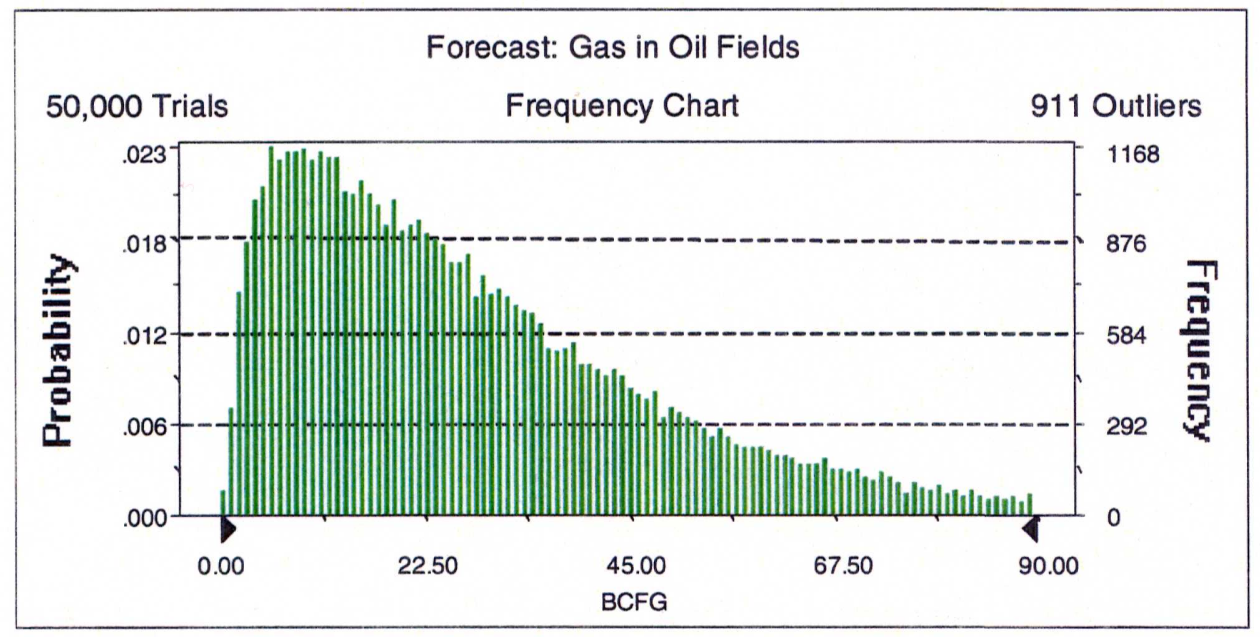


50500101

Lower Cretaceous Shoal-Reef Oil

Monte Carlo Results

Forecast: Gas in Undiscovered Oil Fields (cont'd)

Percentiles:

$\begin{array}{rr}\text { Percentile } & \text { BCFG } \\ 100 \% & 0.30 \\ 95 \% & 4.05 \\ 90 \% & 6.15 \\ 85 \% & 8.11 \\ 80 \% & 10.05 \\ 75 \% & 12.03 \\ 70 \% & 14.06 \\ 65 \% & 16.23 \\ 60 \% & 18.51 \\ 55 \% & 20.90 \\ 50 \% & 23.36 \\ 45 \% & 26.02 \\ 40 \% & 28.95 \\ 35 \% & 32.11 \\ 30 \% & 35.61 \\ 25 \% & 39.79 \\ 20 \% & 44.62 \\ 15 \% & 50.69 \\ 10 \% & 59.16 \\ 6 \% & 72.43 \\ 0 \% & 174.06\end{array}$

End of Forecast 
50500101

Lower Cretaceous Shoal-Reef Oil

Monte Carlo Results

Forecast: NGL in Undiscovered Oil Fields

Summary:

Display range is from 0.00 to $5.50 \mathrm{MMBNGL}$

Entire range is from 0.02 to $12.57 \mathrm{MMBNGL}$

After 50,000 trials, the standard error of the mean is 0.01

Statistics:

Trials

Value

Mean 50000

Median

1.72

Mode

1.36

Standard Deviation

1.39

Variance

1.93

Skewness

1.54

Kurtosis

6.25

Coefficient of Variability

0.81

Range Minimum

0.02

Range Maximum

12.57

Range Width

12.56

Mean Standard Error

0.01

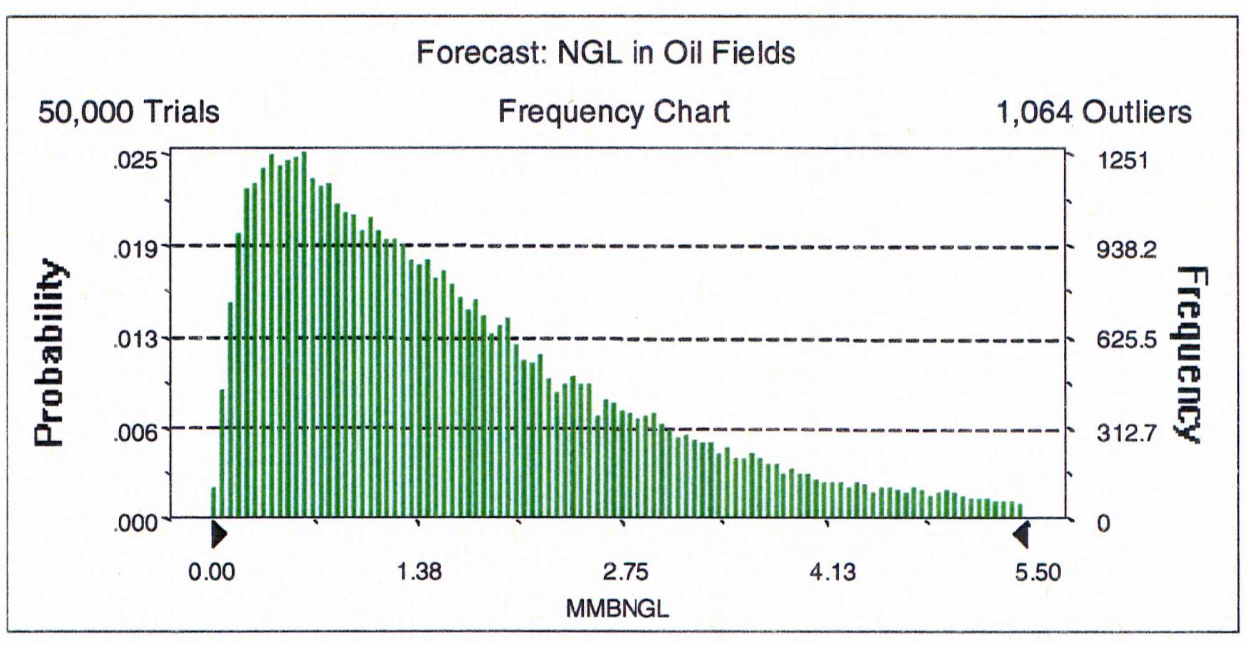


Forecast: NGL in Undiscovered Oil Fields (cont'd)

Percentiles:

\begin{tabular}{rr} 
Percentile & MMBNGL \\
\hline $100 \%$ & 0.02 \\
$95 \%$ & 0.23 \\
$90 \%$ & 0.35 \\
$85 \%$ & 0.46 \\
$80 \%$ & 0.58 \\
$75 \%$ & 0.69 \\
$70 \%$ & 0.81 \\
$65 \%$ & 0.94 \\
$60 \%$ & 1.07 \\
$55 \%$ & 1.21 \\
$50 \%$ & 1.36 \\
$45 \%$ & 1.52 \\
$40 \%$ & 1.69 \\
$35 \%$ & 1.89 \\
$30 \%$ & 2.10 \\
$25 \%$ & 2.37 \\
$20 \%$ & 2.68 \\
$15 \%$ & 3.07 \\
$10 \%$ & 3.60 \\
$5 \%$ & 4.52 \\
$0 \%$ & 12.57 \\
\hline &
\end{tabular}

End of Forecast 
50500101

Lower Cretaceous Shoal-Reef Oil

Monte Carlo Results

\section{Forecast: Largest Undiscovered Oil Field}

Summary:

Display range is from 0.00 to $175.00 \mathrm{MMBO}$

Entire range is from 1.86 to $200.00 \mathrm{MMBO}$

After 50,000 trials, the standard error of the mean is 0.17

$\begin{array}{lr}\text { Statistics: } & \text { Value } \\ \text { Trials } & 50000 \\ \text { Mean } & 55.94 \\ \text { Median } & 46.51 \\ \text { Mode } & -\overline{1} \\ \text { Standard Deviation } & 37.06 \\ \text { Variance } & 1,373.67 \\ \text { Skewness } & 1.29 \\ \text { Kurtosis } & 4.59 \\ \text { Coefficient of Variability } & 0.66 \\ \text { Range Minimum } & 1.86 \\ \text { Range Maximum } & 200.00 \\ \text { Range Width } & 198.13 \\ \text { Mean Standard Error } & 0.17\end{array}$

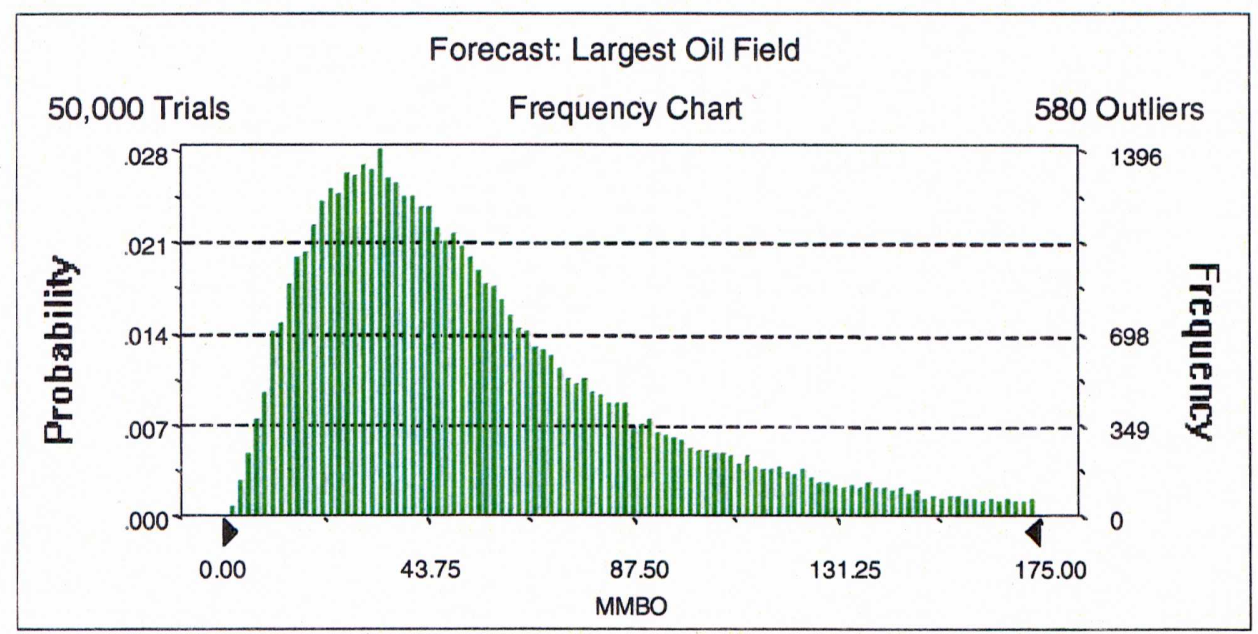


50500101

Lower Cretaceous Shoal-Reef Oil

Monte Carlo Results

Forecast: Largest Undiscovered Oil Field (cont'd)

Percentiles:

\begin{tabular}{rr} 
Percentile & MMBO \\
\hline $100 \%$ & 1.86 \\
$95 \%$ & 13.51 \\
$90 \%$ & 18.30 \\
$85 \%$ & 22.22 \\
$80 \%$ & 25.75 \\
$75 \%$ & 29.15 \\
$70 \%$ & 32.45 \\
$65 \%$ & 35.71 \\
$60 \%$ & 39.12 \\
$55 \%$ & 42.76 \\
$50 \%$ & 46.51 \\
$45 \%$ & 50.66 \\
$40 \%$ & 55.01 \\
$35 \%$ & 60.01 \\
$30 \%$ & 65.81 \\
$25 \%$ & 72.75 \\
$20 \%$ & 81.30 \\
$15 \%$ & 92.31 \\
$10 \%$ & 108.16 \\
$5 \%$ & 133.76 \\
$0 \%$ & 200.00 \\
& \\
&
\end{tabular}

End of Forecast 
50500101

Lower Cretaceous Shoal-Reef Oil

Monte Carlo Results

\section{Forecast: Oil in Undiscovered Oil Fields in Big Cypress}

\section{Summary:}

Display range is from 0.00 to $70.00 \mathrm{MMBO}$

Entire range is from 0.29 to $111.88 \mathrm{MMBO}$

After 50,000 trials, the standard error of the mean is 0.07

$\begin{array}{lr}\text { Statistics: } & \text { Value } \\ \text { Trials } & 50000 \\ \text { Mean } & 24.01 \\ \text { Median } & 20.60 \\ \text { Mode } & -- \\ \text { Standard Deviation } & 16.66 \\ \text { Variance } & 277.54 \\ \text { Skewness } & 0.95 \\ \text { Kurtosis } & 3.68 \\ \text { Coefficient of Variability } & 0.69 \\ \text { Range Minimum } & 0.29 \\ \text { Range Maximum } & 111.88 \\ \text { Range Width } & 11.59 \\ \text { Mean Standard Error } & 0.07\end{array}$

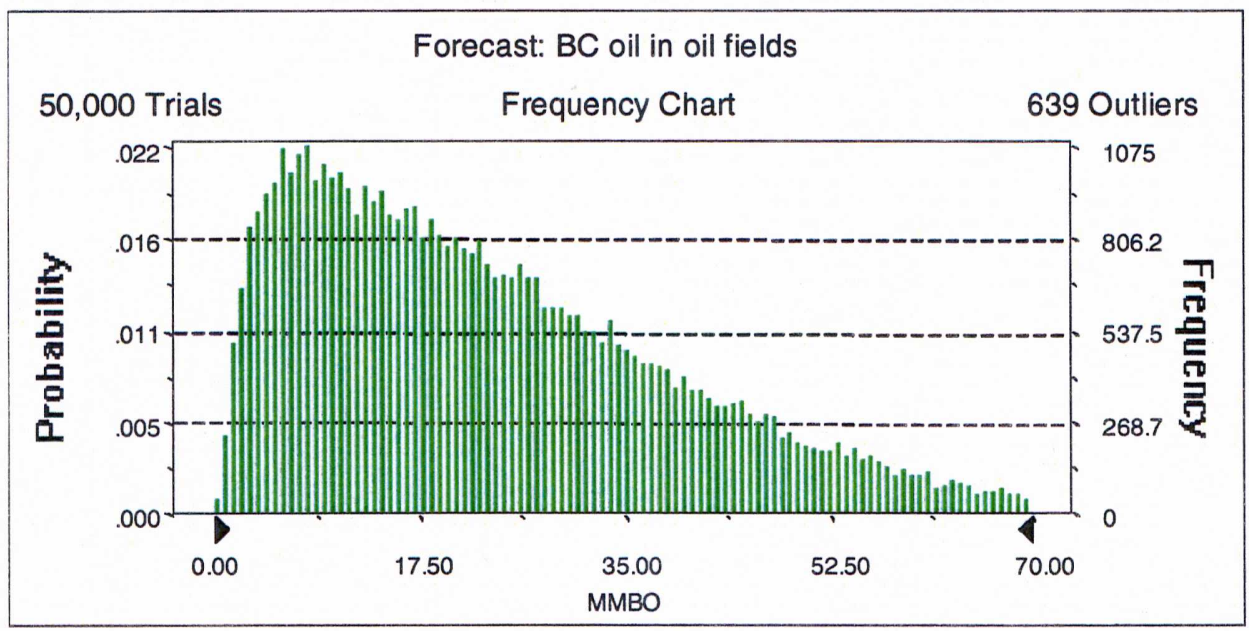


50500101

Lower Cretaceous Shoal-Reef Oil

Monte Carlo Results

Forecast: Oil in Undiscovered Oil Fields in Big Cypress (cont'd)

Percentiles:

\begin{tabular}{rr} 
Percentile & MMBO \\
\hline $100 \%$ & 0.29 \\
$95 \%$ & 3.67 \\
$90 \%$ & 5.56 \\
$85 \%$ & 7.24 \\
$80 \%$ & 8.92 \\
$75 \%$ & 10.67 \\
$70 \%$ & 12.54 \\
$65 \%$ & 14.44 \\
$60 \%$ & 16.40 \\
$55 \%$ & 18.43 \\
$50 \%$ & 20.60 \\
$45 \%$ & 22.84 \\
$40 \%$ & 25.28 \\
$35 \%$ & 27.80 \\
$30 \%$ & 30.70 \\
$25 \%$ & 33.94 \\
$20 \%$ & 37.62 \\
$15 \%$ & 42.01 \\
$10 \%$ & 47.60 \\
$5 \%$ & 56.18 \\
$0 \%$ & 111.88 \\
\hline &
\end{tabular}

End of Forecast

Page $\mathrm{Cl}$ 
50500101

Lower Cretaceous Shoal-Reef Oil

Monte Carlo Results

\section{Forecast: Gas in Undiscovered Oil Fields in Big Cypress}

Summary:

Display range is from 0.00 to $8.00 \mathrm{BCFG}$

Entire range is from 0.02 to $18.19 \mathrm{BCFG}$

After 50,000 trials, the standard error of the mean is 0.01

Statistics:

Trials

Value

Mean

50000

Median

2.54

Mode

Standard Deviation

2.02

Variance

$-$

2.02

Skewness

4.07

1.51

Kurtosis

6.11

Coefficient of Variability

0.80

Range Minimum

0.02

Range Maximum

18.19

Range Width

18.17

Mean Standard Error

0.01

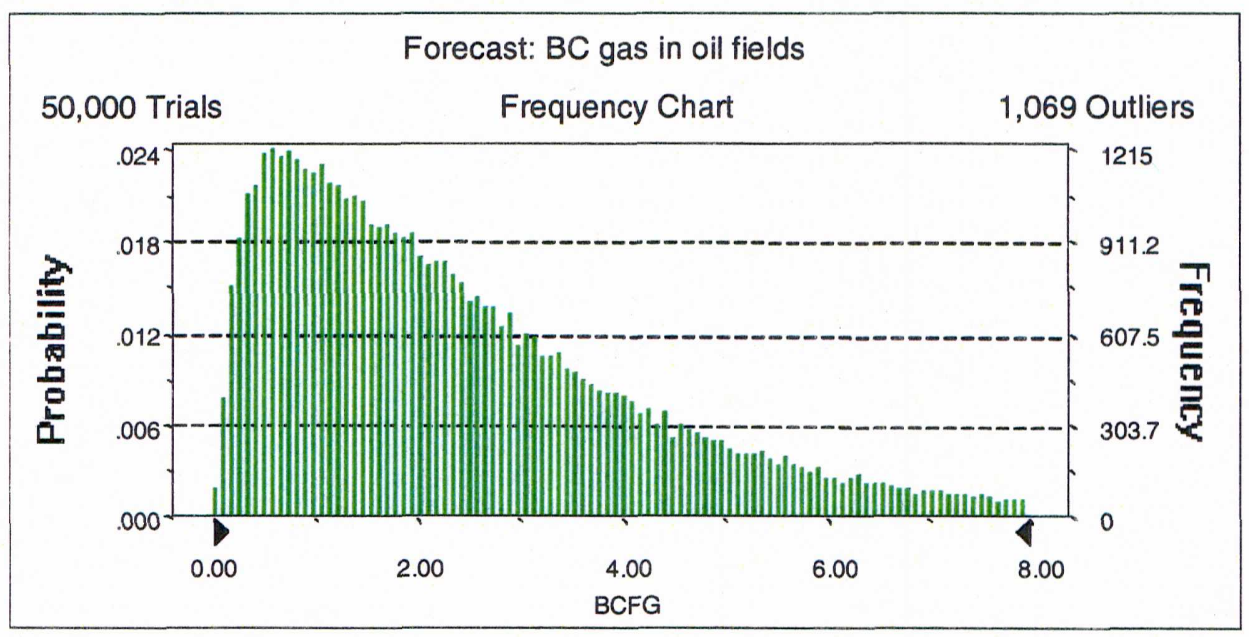


50500101

Lower Cretaceous Shoal-Reef Oil

Monte Carlo Results

Forecast: Gas in Undiscovered Oil Fields in Big Cypress (cont'd)

Percentiles:

\begin{tabular}{rr} 
Percentile & BCFG \\
\hline $100 \%$ & 0.02 \\
$95 \%$ & 0.34 \\
$90 \%$ & 0.53 \\
$85 \%$ & 0.69 \\
$80 \%$ & 0.86 \\
$75 \%$ & 1.03 \\
$70 \%$ & 1.21 \\
$65 \%$ & 1.39 \\
$60 \%$ & 1.59 \\
$55 \%$ & 1.80 \\
$50 \%$ & 2.02 \\
$45 \%$ & 2.26 \\
$40 \%$ & 2.51 \\
$35 \%$ & 2.80 \\
$30 \%$ & 3.12 \\
$25 \%$ & 3.48 \\
$20 \%$ & 3.93 \\
$15 \%$ & 4.48 \\
$10 \%$ & 5.26 \\
$5 \%$ & 6.53 \\
$0 \%$ & 18.19 \\
\hline &
\end{tabular}

End of Forecast 
50500101

Lower Cretaceous Shoal-Reef Oil

Monte Carlo Results

\section{Forecast: NGL in Undiscovered Oil Fields in Big Cypress}

$\begin{array}{lr}\text { Summary: } \\ \text { Display range is from 0.00 to 0.50 MMBNGL } \\ \text { Entire range is from 0.00 to 1.26 MMBNGL } \\ \text { After 50,000 trials, the standard error of the mean is } 0.00 \\ \text { Statistics: } & \underline{\text { Value }} \\ \text { Trials } & 50000 \\ \text { Mean } & 0.15 \\ \text { Median } & 0.12 \\ \text { Mode } & -1 . \\ \text { Standard Deviation } & 0.13 \\ \text { Variance } & 0.02 \\ \text { Skewness } & 1.68 \\ \text { Kurtosis } & 7.03 \\ \text { Coefficient of Variability } & 0.83 \\ \text { Range Minimum } & 0.00 \\ \text { Range Maximum } & 1.26 \\ \text { Range Width } & 1.26 \\ \text { Mean Standard Error } & 0.00\end{array}$

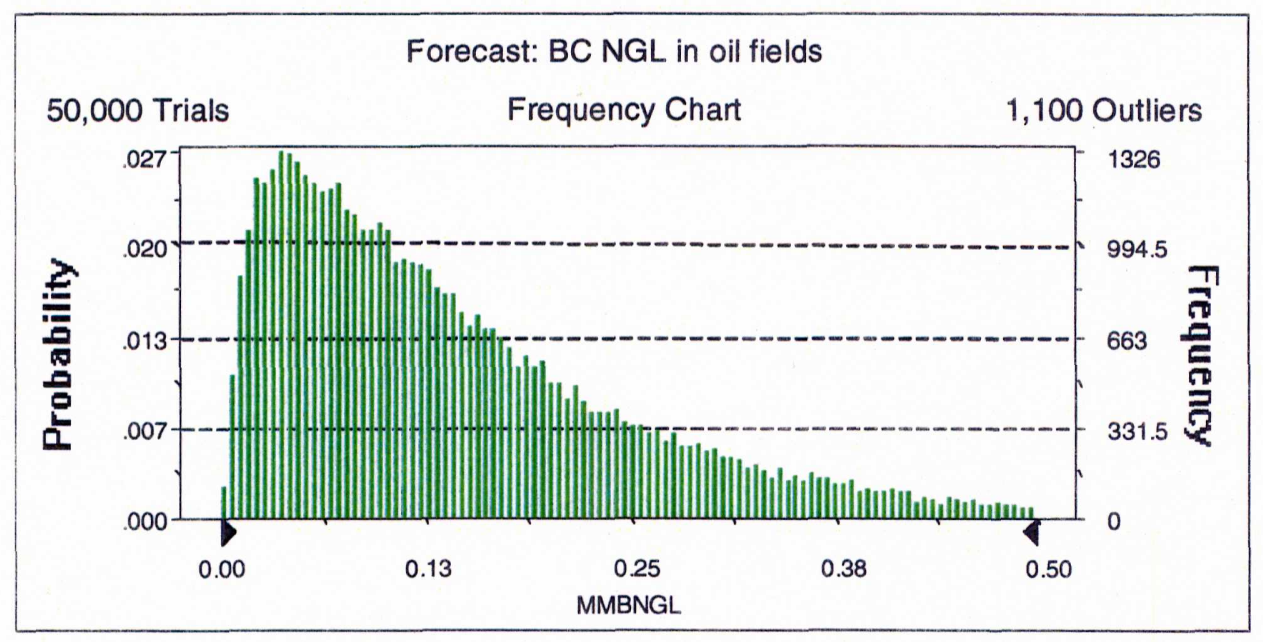


Forecast: NGL in Undiscovered Oil Fields in Big Cypress (cont'd)

Percentiles:

\begin{tabular}{rr} 
Percentile & MMBNGL \\
\hline $100 \%$ & 0.00 \\
$95 \%$ & 0.02 \\
$90 \%$ & 0.03 \\
$85 \%$ & 0.04 \\
$80 \%$ & 0.05 \\
$75 \%$ & 0.06 \\
$70 \%$ & 0.07 \\
$65 \%$ & 0.08 \\
$60 \%$ & 0.09 \\
$55 \%$ & 0.10 \\
$50 \%$ & 0.12 \\
$45 \%$ & 0.13 \\
$40 \%$ & 0.15 \\
$35 \%$ & 0.16 \\
$30 \%$ & 0.18 \\
$25 \%$ & 0.21 \\
$20 \%$ & 0.24 \\
$15 \%$ & 0.27 \\
$10 \%$ & 0.32 \\
$5 \%$ & 0.40 \\
$0 \%$ & 1.26 \\
\hline &
\end{tabular}

End of Forecast 


\section{Assumptions}

\section{Assumption: Number of Undiscovered Oil Fields}

Triangular distribution with parameters:

Minimum

Likeliest

Maximum

75

Selected range is from 2 to 75

Mean value in simulation was 28

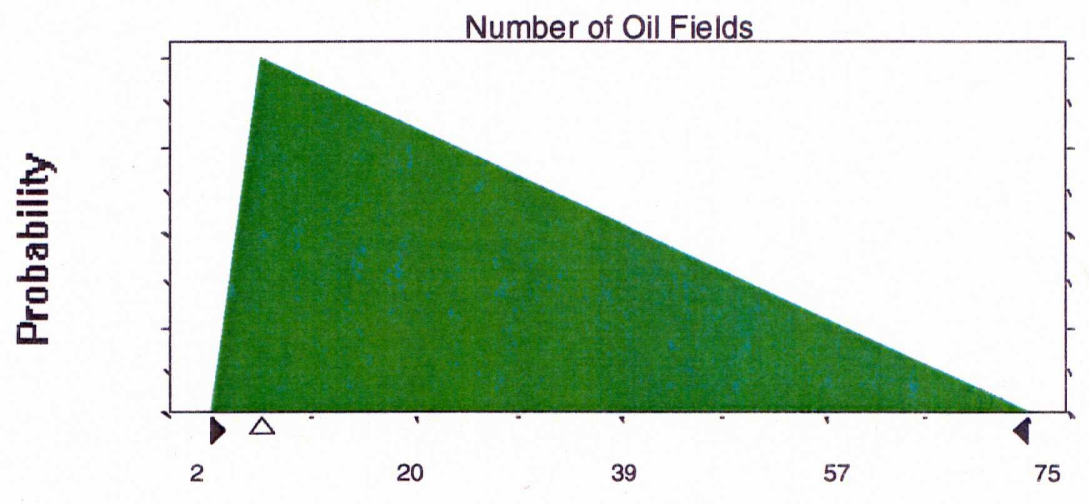

\section{Assumption: Sizes of Undiscovered Oil Fields}

Lognormal distribution with parameters:

Mean

Standard Deviation

9.55

17.89
Shifted parameters

10.05

17.89

0.50 to 200.00

9.75

Selected range is from 0.00 to 199.50

Mean value in simulation was 9.25 
Assumption: Sizes of Undiscovered Oil Fields (cont'd)

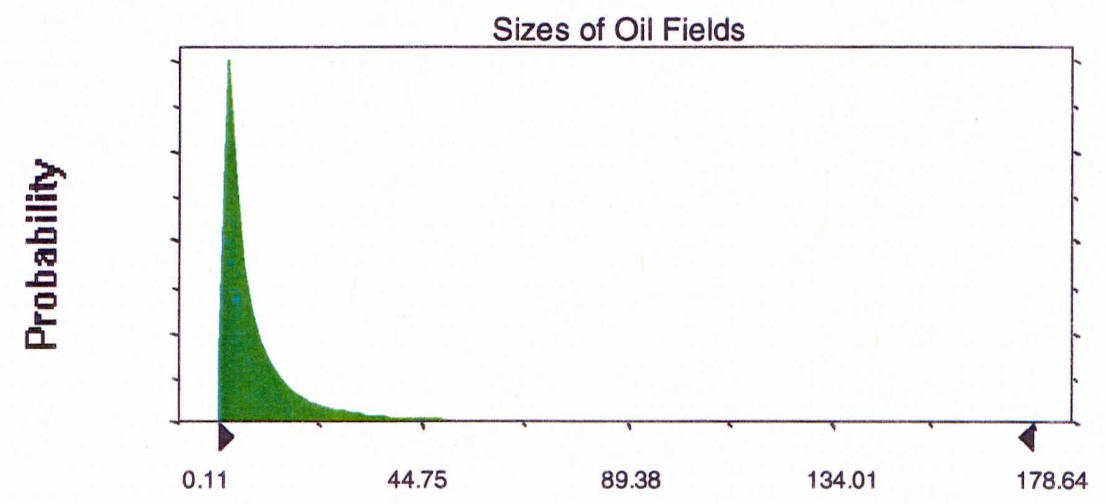

\section{Assumption: GOR in Undiscovered Oil Fields}

Triangular distribution with parameters:

$\begin{array}{lr}\text { Minimum } & 50.00 \\ \text { Likeliest } & 66.67 \\ \text { Maximum } & 200.00\end{array}$

Selected range is from 50.00 to 200.00

Mean value in simulation was 105.57

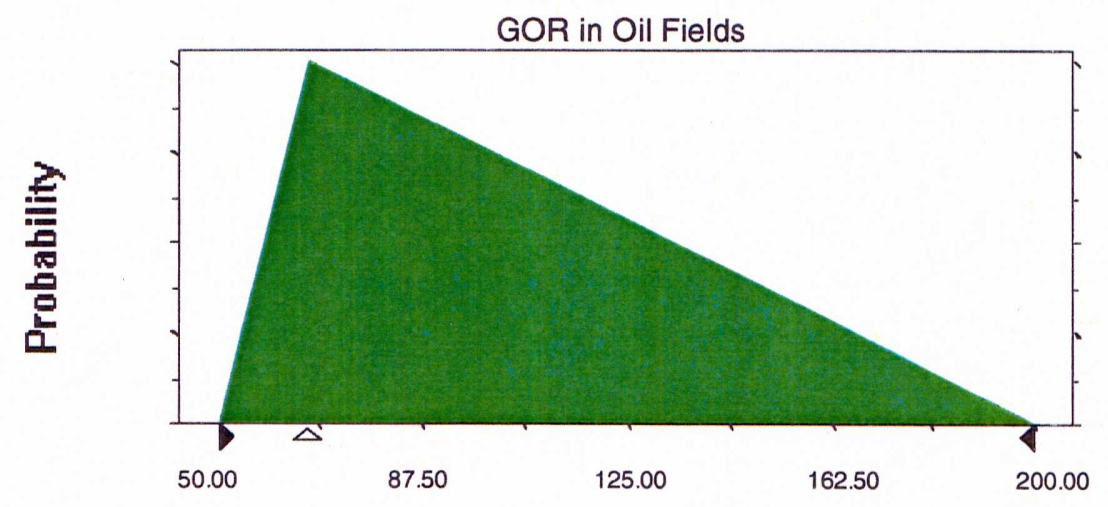


50500101

Lower Cretaceous Shoal-Reef Oil

Monte Carlo Results

\section{Assumption: LGR in Undiscovered Oil Fields}

Triangular distribution with parameters:

Minimum

30.00

Likeliest

60.00

Maximum

90.00

Selected range is from 30.00 to 90.00

Mean value in simulation was 59.94

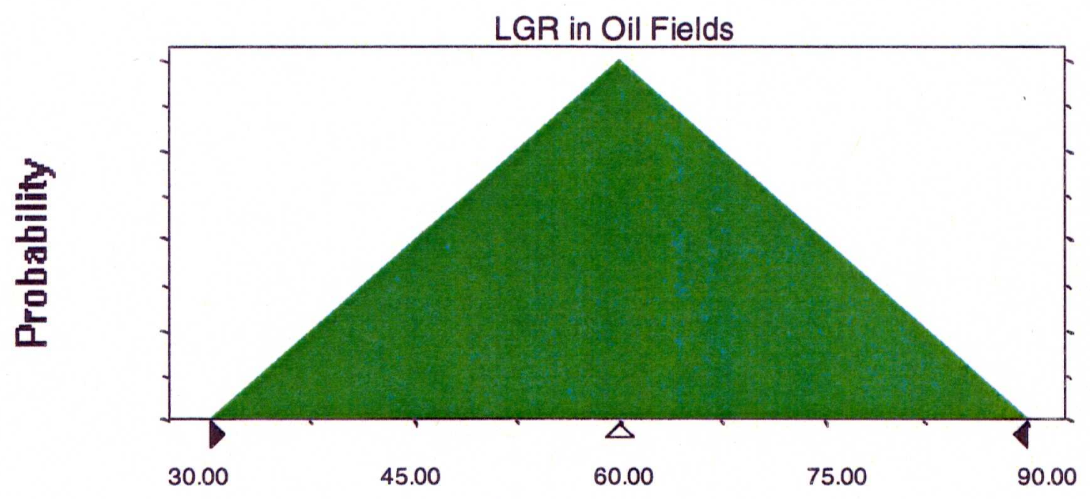

Assumption: Undiscovered Oil \% in Big Cypress

Triangular distribution with parameters:

Minimum

5.00

Likeliest

9.43

Maximum

12.00

Selected range is from 5.00 to 12.00

Mean value in simulation was 8.80 


\section{Assumption: Undiscovered Oil \% in Big Cypress (cont'd)}

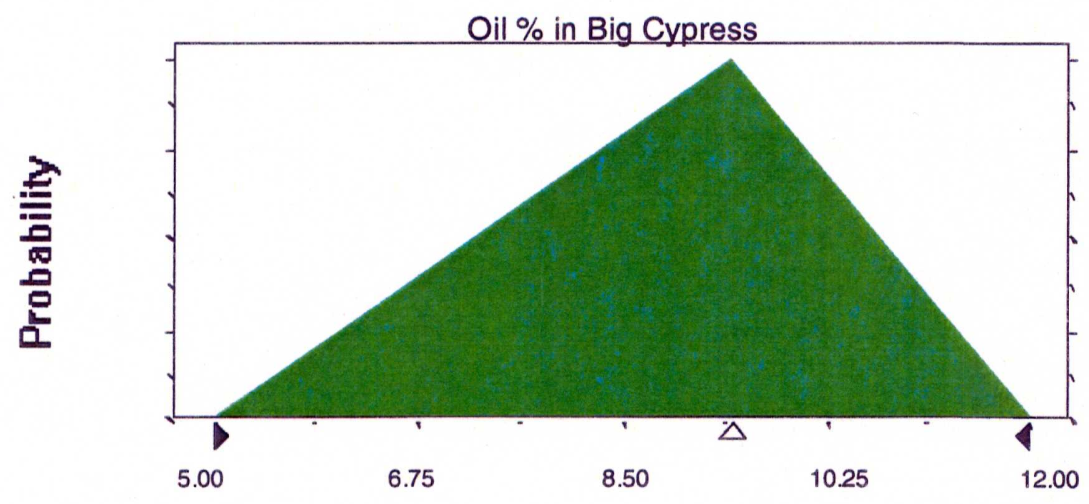

End of Assumptions

Simulation started on 5/26/00 at 15:46:45

Simulation stopped on 5/26/00 at 16:20:01 
Appendix D

Monte Carlo Output

For Assessment Unit 50500201

Pre-Punta Gorda Dolomite Gas and Oil Hypothetical

Contained in this appendix are detailed descriptions of the probability distributions of the results of the assessment of AU 50500201, the Pre-Punta Gorda Dolomite Gas and Oil Hypothetical Assessment Unit. These details may be of use to those pursuing further analysis of the results. All distributions in this appendix are fully risked. They include the probability of there being no oil or gas fields of minimum size or larger. The first seven distributions (pages D2 to D15) describe the results for the entire assessment unit. The next five (pages D16 to D25) describe the results allocated to Big Cypress National Preserve. Each distribution is documented by two pages. On the first page are the distribution parameters, most importantly the mean, as well as a graph of the probability density function. The second page lists the percentiles (fractiles) of the distribution at $5 \%$ intervals.

Also included in Appendix D (pages D26 to D31) are the descriptions of probability distributions of the input based on the input parameters documented in Appendix B. Each of the distributions used in calculating the results is documented by its parameters and a graph of the probability density function. Note that for the distribution of size of undiscovered oil fields (pages D26 and D27) and for the distribution of size of undiscovered gas fields (page D29), the parameters of both the shifted and unshifted lognormal distributions are given. The accompanying graph is that of the unshifted distribution. 


\section{Forecast: Geologic-Risked Oil in Undiscovered Oill Fields}

Summary:

Display range is from 0.00 to $300.00 \mathrm{MMBO}$

Entire range is from 0.00 to $786.78 \mathrm{MMBO}$

After 50,000 trials, the standard error of the mean is 0.35

Statistics:

Trials

Value

Mean

50000

Median

78.69

Mode

57.50

Standard Deviation

0.00

Variance

77.35

Skewness

$5,982.29$

Kurtosis

1.63

Coefficient of Variability

6.73

Range Minimum

0.98

Range Maximum

0.00

Range Width

786.78

Mean Standard Error

786.78

0.35

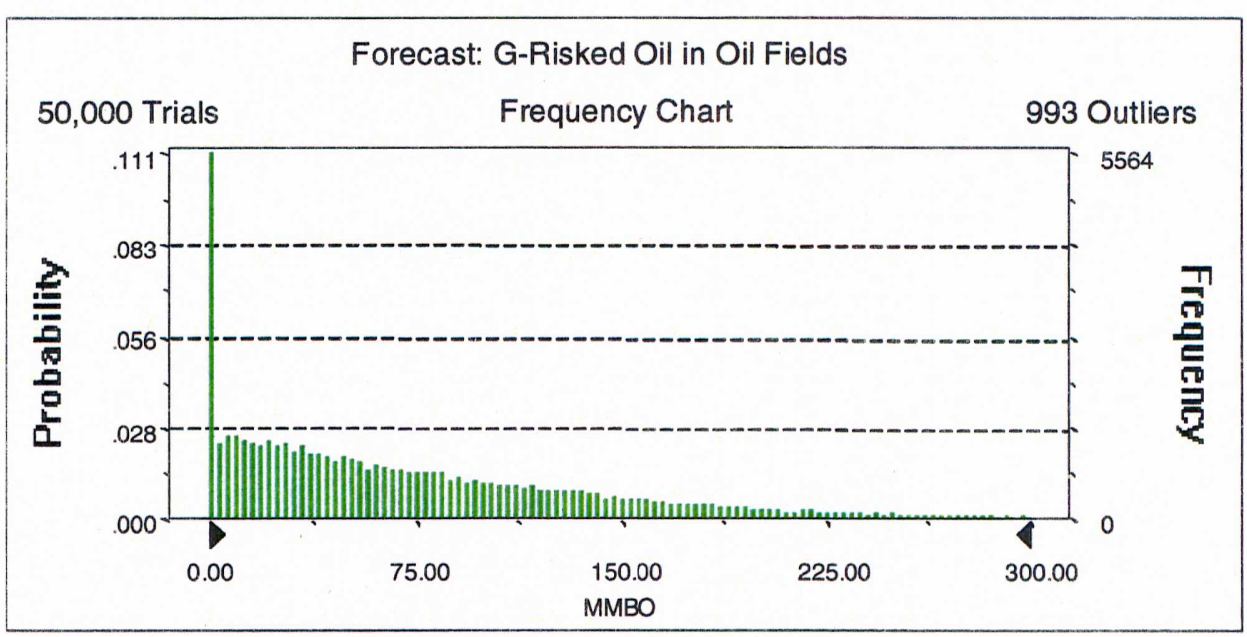


50500201

Pre-Punta Gorda Dolomite Gas and Oil

Monte Carlo Results

Forecast: Geologic-Risked Oil in Undiscovered Oil Fields (cont'd)

Percentiles:

\begin{tabular}{rr} 
Percentile & MMBO \\
\hline $100 \%$ & 0.00 \\
$95 \%$ & 0.00 \\
$90 \%$ & 0.00 \\
$85 \%$ & 7.82 \\
$80 \%$ & 13.81 \\
$75 \%$ & 20.27 \\
$70 \%$ & 26.87 \\
$65 \%$ & 33.77 \\
$60 \%$ & 41.00 \\
$55 \%$ & 49.13 \\
$50 \%$ & 57.50 \\
$45 \%$ & 66.77 \\
$40 \%$ & 77.07 \\
$35 \%$ & 87.80 \\
$30 \%$ & 100.54 \\
$25 \%$ & 114.85 \\
$20 \%$ & 131.77 \\
$15 \%$ & 152.18 \\
$10 \%$ & 181.41 \\
$5 \%$ & 231.16 \\
$0 \%$ & 786.78
\end{tabular}

End of Forecast 


\section{Forecast: Geologic-Risked Gas in Undiscovered Oil Fields}

Summary:

Display range is from 0.00 to $350.00 \mathrm{BCFG}$

Entire range is from 0.00 to $959.60 \mathrm{BCFG}$

After 50,000 trials, the standard error of the mean is 0.40

Statistics:

Trials

Value

Mean

50000

Median

83.25

Mode

56.30

Standard Deviation

0.00

Variance

90.17

Skewness

$8,129.94$

Kurtosis

2.13

9.84

Coefficient of Variability

1.08

Range Minimum

0.00

Range Maximum

959.60

Range Width

959.60

Mean Standard Error

0.40

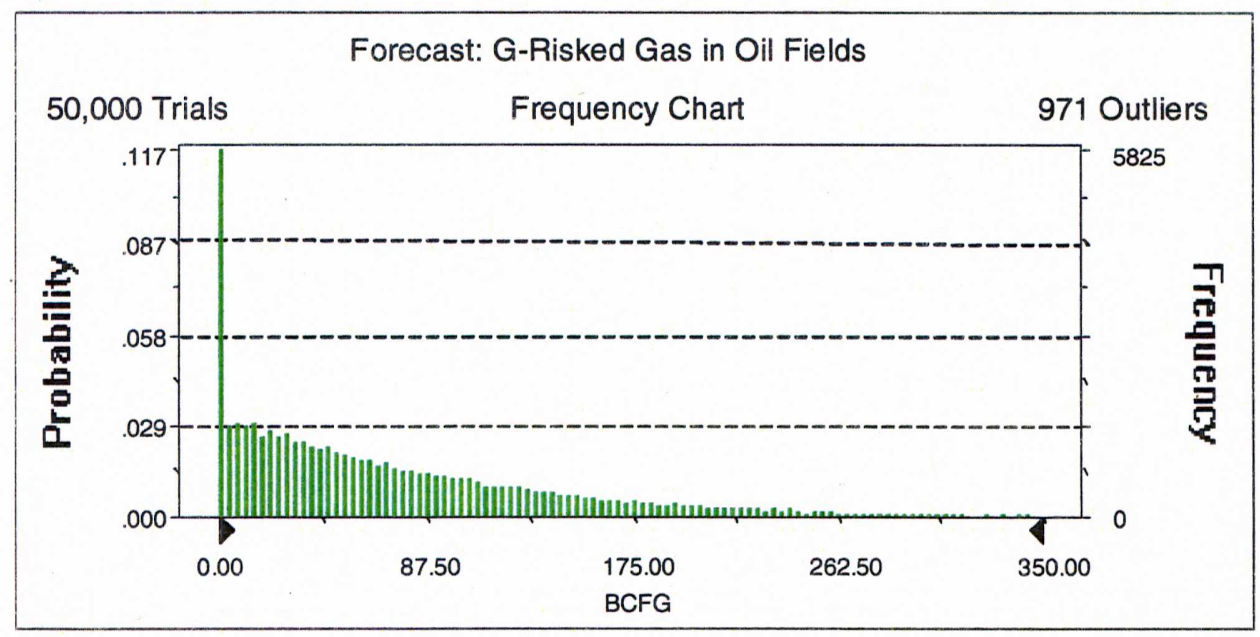


Forecast: Geologic-Risked Gas in Undiscovered Oil Fields (cont'd)

Percentiles:

\begin{tabular}{rr} 
Percentile & BCFG \\
\hline $100 \%$ & 0.00 \\
$95 \%$ & 0.00 \\
$90 \%$ & 0.00 \\
$85 \%$ & 7.42 \\
$80 \%$ & 13.37 \\
$75 \%$ & 19.33 \\
$70 \%$ & 25.86 \\
$65 \%$ & 32.59 \\
$60 \%$ & 39.80 \\
$55 \%$ & 47.79 \\
$50 \%$ & 56.30 \\
$45 \%$ & 65.54 \\
$40 \%$ & 76.03 \\
$35 \%$ & 87.92 \\
$30 \%$ & 101.37 \\
$25 \%$ & 117.29 \\
$20 \%$ & 135.85 \\
$15 \%$ & 160.51 \\
$10 \%$ & 196.84 \\
$5 \%$ & 259.78 \\
$0 \%$ & 959.60
\end{tabular}

End of Forecast 
Pre-Punta Gorda Dolomite Gas and Oil

Monte Carlo Results

\section{Forecast: Geologic-Risked NGL in Undiscovered Oil Fields}

\section{Summary:}

Display range is from 0.00 to $20.00 \mathrm{MMBNGL}$

Entire range is from 0.00 to $68.38 \mathrm{MMBNGL}$

After 50,000 trials, the standard error of the mean is 0.03

Statistics:

Trials

Value

Mean

50000

Median

4.99

Mode

3.27

Standard Deviation

0.00

Variance

5.64

Skewness

31.84

Kurtosis

12.36

Coefficient of Variability

1.13

Range Minimum

0.00

Range Maximum

68.38

Range Width

68.38

Mean Standard Error

0.03

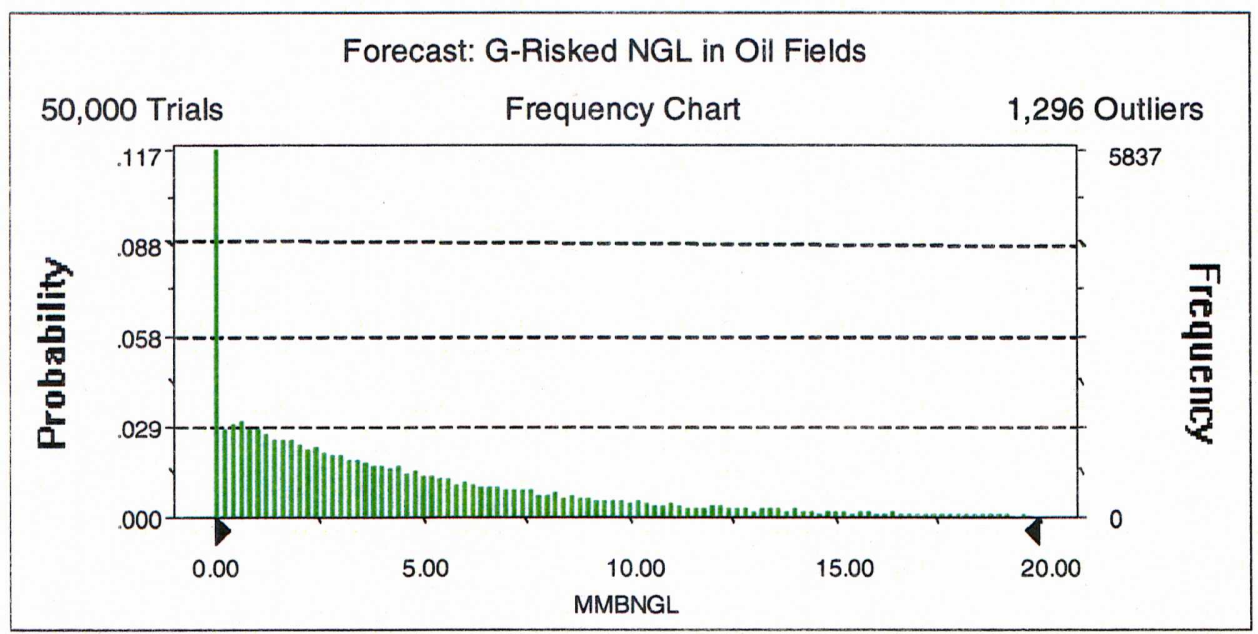


50500201

Pre-Punta Gorda Dolomite Gas and Oil

Monte Carlo Results

Forecast: Geologic-Risked NGL in Undiscovered Oil Fields (cont'd)

Percentiles:

\begin{tabular}{rr} 
Percentile & MMBNGL \\
\hline $100 \%$ & 0.00 \\
$95 \%$ & 0.00 \\
$90 \%$ & 0.00 \\
$85 \%$ & 0.43 \\
$80 \%$ & 0.76 \\
$75 \%$ & 1.11 \\
$70 \%$ & 1.48 \\
$65 \%$ & 1.88 \\
$60 \%$ & 2.30 \\
$55 \%$ & 2.77 \\
$50 \%$ & 3.27 \\
$45 \%$ & 3.83 \\
$40 \%$ & 4.45 \\
$35 \%$ & 5.14 \\
$30 \%$ & 5.95 \\
$25 \%$ & 6.92 \\
$20 \%$ & 8.09 \\
$15 \%$ & 9.62 \\
$10 \%$ & 11.89 \\
$5 \%$ & 15.94 \\
$0 \%$ & 68.38
\end{tabular}

End of Forecast 
Forecast: Largest Undiscovered Oil Field

Summary:

Display range is from 0.00 to $150.00 \mathrm{MMBO}$

Entire range is from 0.52 to $299.61 \mathrm{MMBO}$

After 50,000 trials, the standard error of the mean is 0.18

$\begin{array}{lr}\text { Statistics: } & \text { Value } \\ \text { Trials } & 50000 \\ \text { Mean } & 38.61 \\ \text { Median } & 25.43 \\ \text { Mode } & - \\ \text { Standard Deviation } & 41.02 \\ \text { Variance } & 1,682.59 \\ \text { Skewness } & 2.52 \\ \text { Kurtosis } & 11.14 \\ \text { Coefficient of Variability } & 1.06 \\ \text { Range Minimum } & 0.52 \\ \text { Range Maximum } & 299.61 \\ \text { Range Width } & 299.09 \\ \text { Mean Standard Error } & 0.18\end{array}$

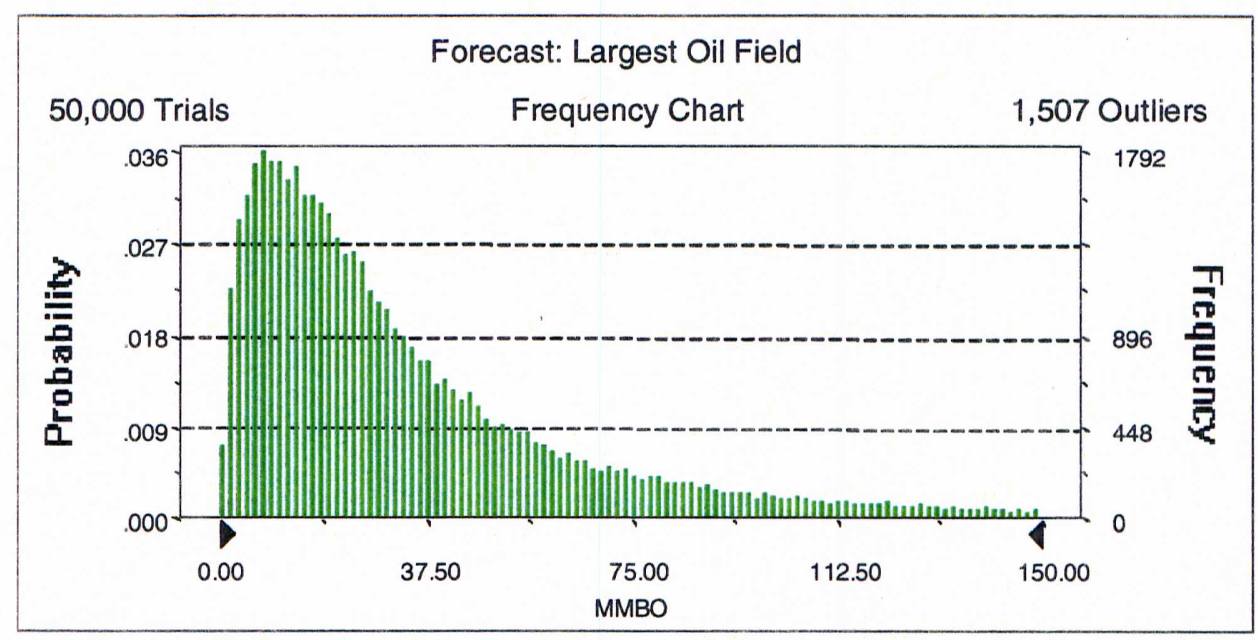


Forecast: Largest Undiscovered Oil Field (cont'd)

Percentiles:

\begin{tabular}{rr} 
Percentile & MMBO \\
\hline $100 \%$ & 0.52 \\
$95 \%$ & 4.04 \\
$90 \%$ & 6.44 \\
$85 \%$ & 8.54 \\
$80 \%$ & 10.66 \\
$75 \%$ & 12.87 \\
$70 \%$ & 15.06 \\
$65 \%$ & 17.43 \\
$60 \%$ & 19.87 \\
$55 \%$ & 22.53 \\
$50 \%$ & 25.43 \\
$45 \%$ & 28.60 \\
$40 \%$ & 32.31 \\
$35 \%$ & 36.65 \\
$30 \%$ & 41.87 \\
$25 \%$ & 48.15 \\
$20 \%$ & 56.48 \\
$15 \%$ & 68.23 \\
$10 \%$ & 86.26 \\
$5 \%$ & 121.61 \\
$0 \%$ & 299.61
\end{tabular}

End of Forecast 


\section{Forecast: Geologic-Risked Gas in Undiscovered Gas Fields}

Summary:

Display range is from 0.00 to $5,000.00$ BCFG

Entire range is from 0.00 to $8,837.54 \mathrm{BCFG}$

After 50,000 trials, the standard error of the mean is 5.66

$\begin{array}{lr}\text { Statistics: } & \text { Value } \\ \text { Trials } & 50000 \\ \text { Mean } & 1,545.41 \\ \text { Median } & 1,288.97 \\ \text { Mode } & 0.00 \\ \text { Standard Deviation } & 1,266.44 \\ \text { Variance } & 1,603,873.60 \\ \text { Skewness } & 0.91 \\ \text { Kurtosis } & 3.56 \\ \text { Coefficient of Variability } & 0.82 \\ \text { Range Minimum } & 0.00 \\ \text { Range Maximum } & 8,837.54 \\ \text { Range Width } & 8,837.54 \\ \text { Mean Standard Error } & 5.66\end{array}$

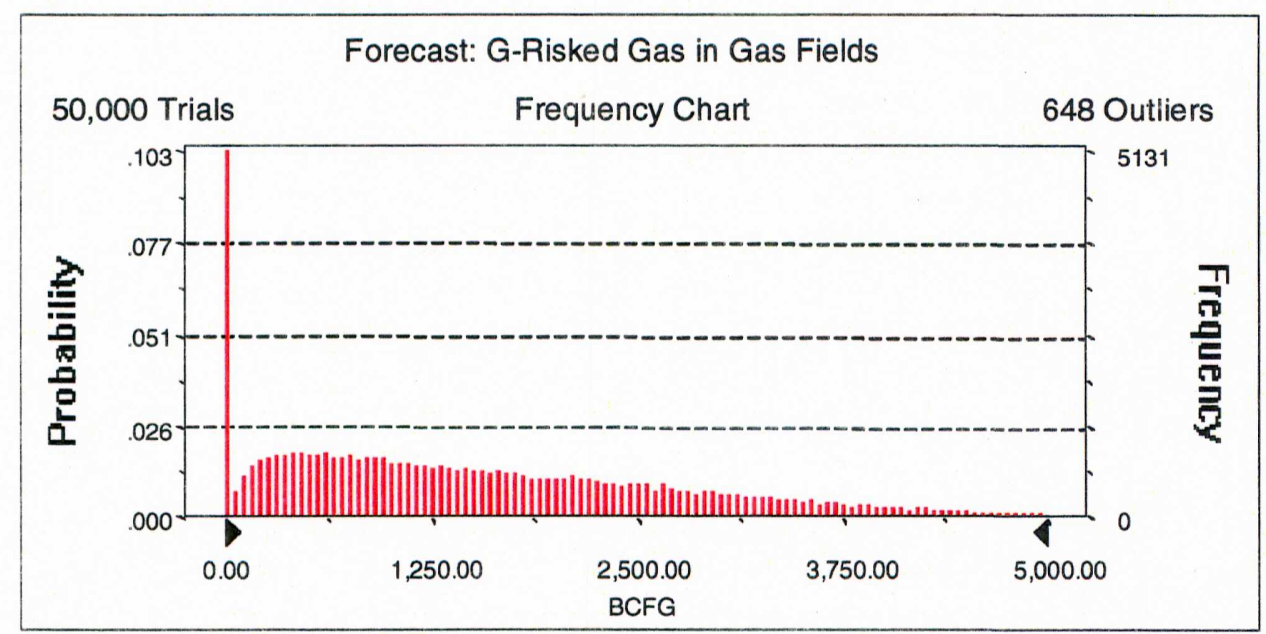


Forecast: Geologic-Risked Gas in Undiscovered Gas Fields (cont'd)

Percentiles:

\begin{tabular}{rr} 
Percentile & BCFG \\
\hline $100 \%$ & 0.00 \\
$95 \%$ & 0.00 \\
$90 \%$ & 0.00 \\
$85 \%$ & 240.93 \\
$80 \%$ & 383.88 \\
$75 \%$ & 522.23 \\
$70 \%$ & 662.26 \\
$65 \%$ & 808.38 \\
$60 \%$ & 959.29 \\
$55 \%$ & $1,116.40$ \\
$50 \%$ & $1,288.97$ \\
$45 \%$ & $1,471.04$ \\
$40 \%$ & $1,662.65$ \\
$35 \%$ & $1,866.24$ \\
$30 \%$ & $2,091.40$ \\
$25 \%$ & $2,325.76$ \\
$20 \%$ & $2,594.55$ \\
$15 \%$ & $2,922.48$ \\
$10 \%$ & $3,330.87$ \\
$5 \%$ & $3,951.48$ \\
$0 \%$ & $8,837.54$
\end{tabular}

End of Forecast 
50500201

Pre-Punta Gorda Dolomite Gas and Oil

Monte Carlo Results

\section{Forecast: Geologic-Risked Liquids in Undiscovered Gas Fields}

\begin{tabular}{|c|c|}
\hline $\begin{array}{l}\text { Summary: } \\
\text { Display range is from } 0.00 \\
\text { Entire range is from } 0.00 \\
\text { After } 50,000 \text { trials, the sta }\end{array}$ & \\
\hline Statistics: & Value \\
\hline Trials & 50000 \\
\hline Mean & 68.01 \\
\hline Median & 54.77 \\
\hline Mode & 0.00 \\
\hline Standard Deviation & 58.54 \\
\hline Variance & $3,426.85$ \\
\hline Skewness & 1.15 \\
\hline Kurtosis & 4.49 \\
\hline Coefficient of Variability & 0.86 \\
\hline Range Minimum & 0.00 \\
\hline Range Maximum & 509.88 \\
\hline Range Width & 509.88 \\
\hline Mean Standard Error & 0.26 \\
\hline
\end{tabular}

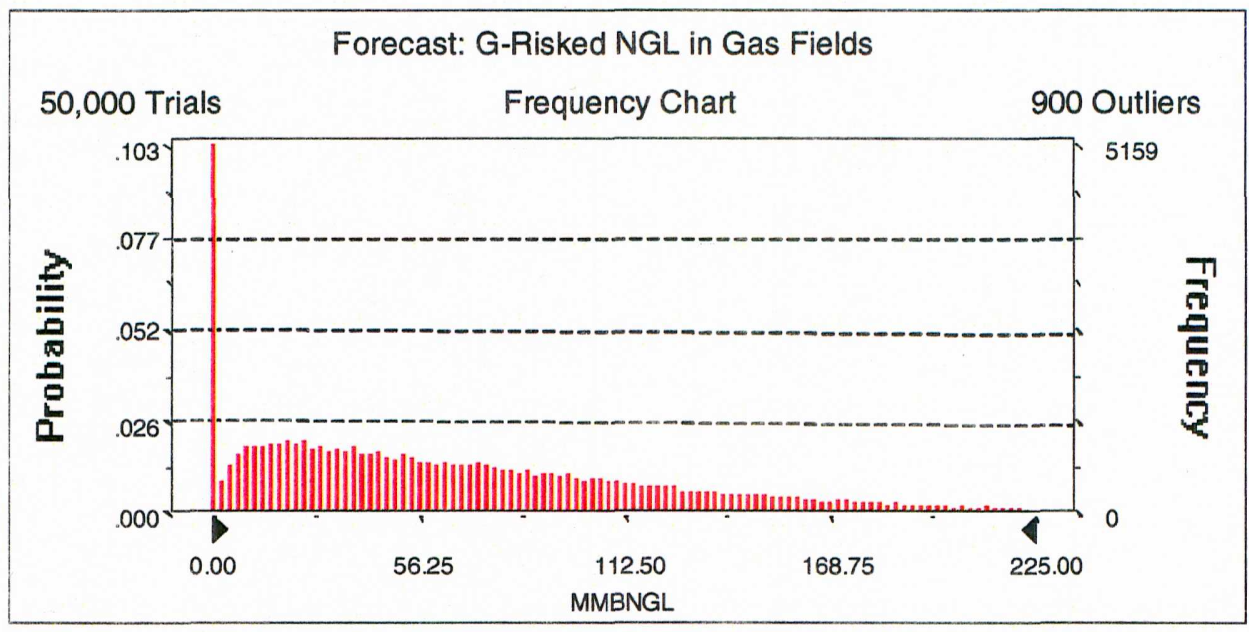


Forecast: Geologic-Risked Liquids in Undiscovered Gas Fields (cont'd)

Percentiles:

\begin{tabular}{r} 
Percentile \\
\hline $100 \%$ \\
$95 \%$ \\
$90 \%$ \\
$85 \%$ \\
$80 \%$ \\
$75 \%$ \\
$70 \%$ \\
$65 \%$ \\
$60 \%$ \\
$55 \%$ \\
$50 \%$ \\
$45 \%$ \\
$40 \%$ \\
$35 \%$ \\
$30 \%$ \\
$25 \%$ \\
$20 \%$ \\
$15 \%$ \\
$10 \%$ \\
$5 \%$ \\
$0 \%$
\end{tabular}

MMBNGL

0.00

0.00

0.00

10.13

16.24

22.01

$70 \%$

27.84

$65 \%$

34.22

$60 \%$

40.55

$55 \%$

47.43

$50 \%$

54.77

$45 \%$

62.73

$40 \%$

71.21

$35 \%$

79.93

$30 \%$

89.94

$25 \%$

100.63

$20 \%$

113.14

$15 \%$

128.54

149.60

$5 \%$

181.55

$0 \%$

509.88

End of Forecast 


\section{Forecast: Largest Undiscovered Gas Field}

\begin{tabular}{|c|c|}
\hline $\begin{array}{l}\text { Summary: } \\
\text { Display range is from } 0.00 \\
\text { Entire range is from } 6.25 \\
\text { After } 50,000 \text { trials, the sta }\end{array}$ & \\
\hline Statistics: & Value \\
\hline Trials & 50000 \\
\hline Mean & 452.11 \\
\hline Median & 345.64 \\
\hline Mode & -- \\
\hline Standard Deviation & 364.20 \\
\hline Variance & $132,639.19$ \\
\hline Skewness & 1.60 \\
\hline Kurtosis & 5.67 \\
\hline Coefficient of Variability & 0.81 \\
\hline Range Minimum & 6.25 \\
\hline Range Maximum & $1,999,94$ \\
\hline Range Width & $1,993.69$ \\
\hline Mean Standard Error & 1.63 \\
\hline
\end{tabular}

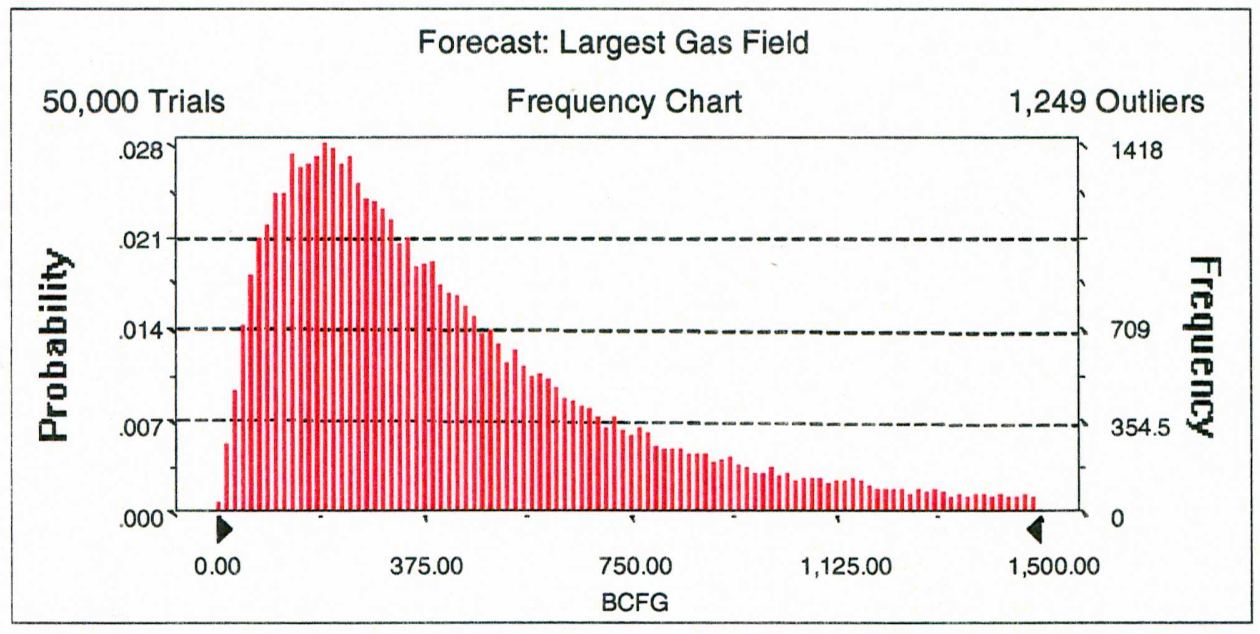


Forecast: Largest Undiscovered Gas Field (cont'd)

Percentiles:

\begin{tabular}{rr} 
Percentile & BCFG \\
\hline $100 \%$ & 6.25 \\
$95 \%$ & 76.48 \\
$90 \%$ & 110.53 \\
$85 \%$ & 140.14 \\
$80 \%$ & 168.25 \\
$75 \%$ & 195.63 \\
$70 \%$ & 222.12 \\
$65 \%$ & 249.79 \\
$60 \%$ & 279.49 \\
$55 \%$ & 310.89 \\
$50 \%$ & 345.64 \\
$45 \%$ & 383.94 \\
$40 \%$ & 424.71 \\
$35 \%$ & 471.72 \\
$30 \%$ & 526.95 \\
$25 \%$ & 592.77 \\
$20 \%$ & 674.07 \\
$15 \%$ & 783.84 \\
$10 \%$ & 945.60 \\
$5 \%$ & 1.232 .37 \\
$0 \%$ & $1,999.94$
\end{tabular}

End of Forecast 


\section{Forecast: Oil in Undiscovered Oil Fields in Big Cypress}

Summary:

Display range is from 0.00 to $15.00 \mathrm{MMBO}$

Entire range is from 0.00 to $38.36 \mathrm{MMBO}$

After 50,000 trials, the standard error of the mean is 0.02

$\begin{array}{lr}\text { Statistics: } & \text { Value } \\ \text { Trials } & 50000 \\ \text { Mean } & 3.94 \\ \text { Median } & 2.75 \\ \text { Mode } & 0.00 \\ \text { Standard Deviation } & 4.09 \\ \text { Variance } & 16.76 \\ \text { Skewness } & 1.89 \\ \text { Kurtosis } & 8.16 \\ \text { Coefficient of Variability } & 1.04 \\ \text { Range Minimum } & 0.00 \\ \text { Range Maximum } & 38.36 \\ \text { Range Width } & 38.36 \\ \text { Mean Standard Error } & 0.02\end{array}$

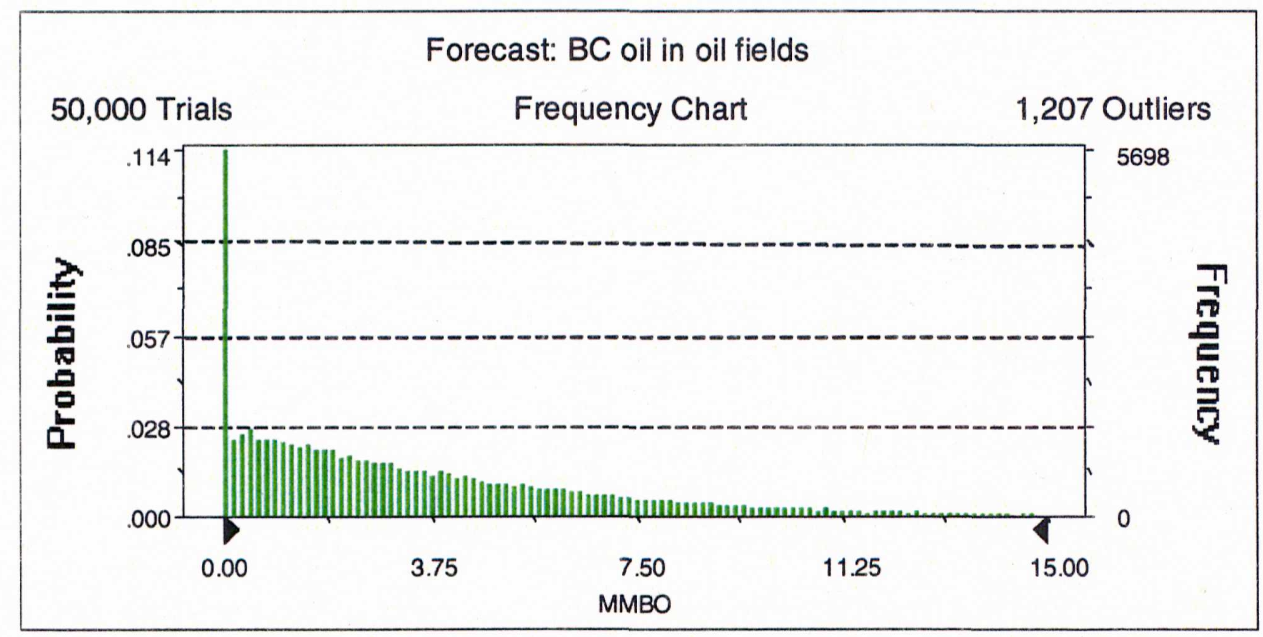


Pre-Punta Gorda Dolomite Gas and Oil

Monte Carlo Results

Forecast: Oil in Undiscovered Oil Fields in Big Cypress (cont'd)

Percentiles:

\begin{tabular}{rr} 
Percentile & MMBO \\
\hline $100 \%$ & 0.00 \\
$95 \%$ & 0.00 \\
$90 \%$ & 0.00 \\
$85 \%$ & 0.36 \\
$80 \%$ & 0.65 \\
$75 \%$ & 0.95 \\
$70 \%$ & 1.26 \\
$65 \%$ & 1.59 \\
$60 \%$ & 1.95 \\
$55 \%$ & 2.33 \\
$50 \%$ & 2.75 \\
$45 \%$ & 3.20 \\
$40 \%$ & 3.70 \\
$35 \%$ & 4.26 \\
$30 \%$ & 4.89 \\
$25 \%$ & 5.64 \\
$20 \%$ & 6.53 \\
$15 \%$ & 7.64 \\
$10 \%$ & 9.21 \\
$5 \%$ & 12.01 \\
$0 \%$ & 38.36
\end{tabular}

End of Forecast 


\section{Forecast: Gas in Undiscovered Oil Fields in Big Cypress}

Summary:

Display range is from 0.00 to $17.50 \mathrm{BCFG}$

Entire range is from 0.00 to $62.06 \mathrm{BCFG}$

After 50,000 trials, the standard error of the mean is 0.02

$\begin{array}{lr}\text { Statistics: } & \text { Value } \\ \text { Trials } & 50000 \\ \text { Mean } & 4.17 \\ \text { Median } & 2.69 \\ \text { Mode } & 0.00 \\ \text { Standard Deviation } & 4.76 \\ \text { Variance } & 22.69 \\ \text { Skewness } & 2.43 \\ \text { Kurtosis } & 12.41 \\ \text { Coefficient of Variability } & 1.14 \\ \text { Range Minimum } & 0.00 \\ \text { Range Maximum } & 62.06 \\ \text { Range Width } & 62.06 \\ \text { Mean Standard Error } & 0.02\end{array}$

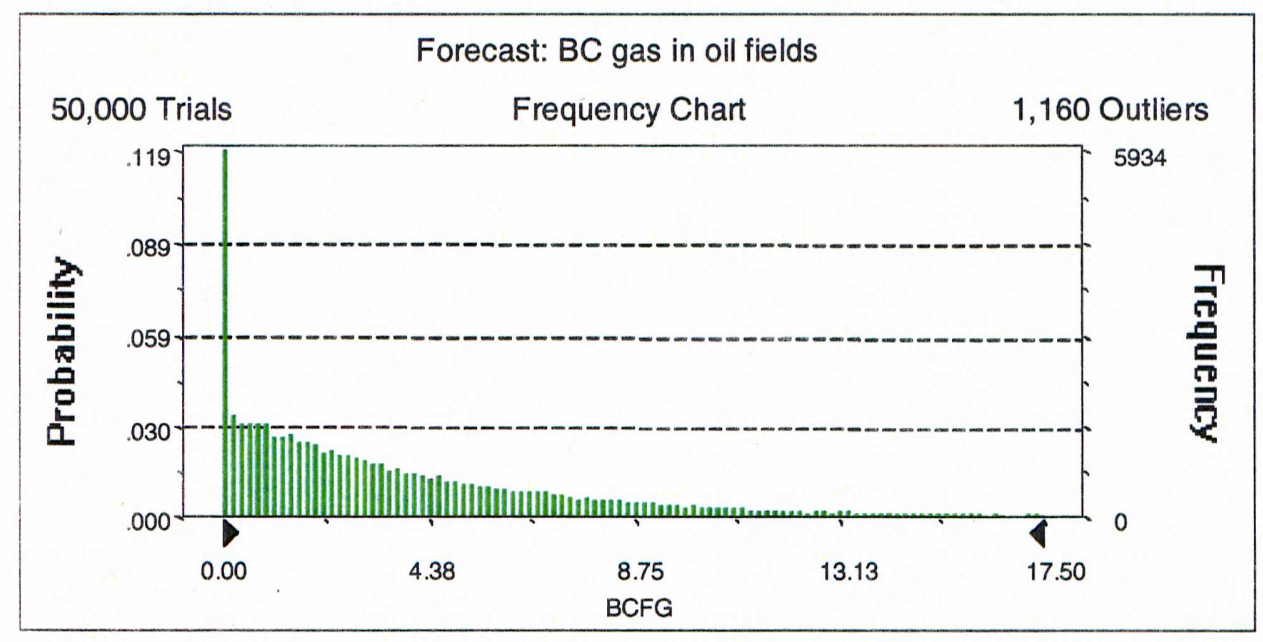


Pre-Punta Gorda Dolomite Gas and Oil

Monte Carlo Results

Forecast: Gas in Undiscovered Oil Fields in Big Cypress (cont'd)

Percentiles:

\begin{tabular}{rr} 
Percentile & BCFG \\
\hline $100 \%$ & 0.00 \\
$95 \%$ & 0.00 \\
$90 \%$ & 0.00 \\
$85 \%$ & 0.34 \\
$80 \%$ & 0.62 \\
$75 \%$ & 0.91 \\
$70 \%$ & 1.22 \\
$65 \%$ & 1.54 \\
$60 \%$ & 1.89 \\
$55 \%$ & 2.28 \\
$50 \%$ & 2.69 \\
$45 \%$ & 3.14 \\
$40 \%$ & 3.66 \\
$35 \%$ & 4.26 \\
$30 \%$ & 4.96 \\
$25 \%$ & 5.76 \\
$20 \%$ & 6.78 \\
$15 \%$ & 8.08 \\
$10 \%$ & 9.96 \\
$5 \%$ & 13.44 \\
$0 \%$ & 62.06
\end{tabular}

End of Forecast 


\section{Forecast: NGL in Undiscovered Oil Fields in Big Cypress}

Summary:

Display range is from 0.00 to $1.10 \mathrm{MMBNGL}$

Entire range is from 0.00 to $4.68 \mathrm{MMBNGL}$

After 50,000 trials, the standard error of the mean is 0.00

Statistics:

Trials

Value

Mean

50000

Median

0.25

Mode

0.16

Standard Deviation

0.00

Variance

0.30

Skewness

0.09

Kurtosis

2.74

Coefficient of Variability

15.83

Range Minimum

1.19

Range Maximum

0.00

Range Width

4.68

Mean Standard Error

4.68

0.00

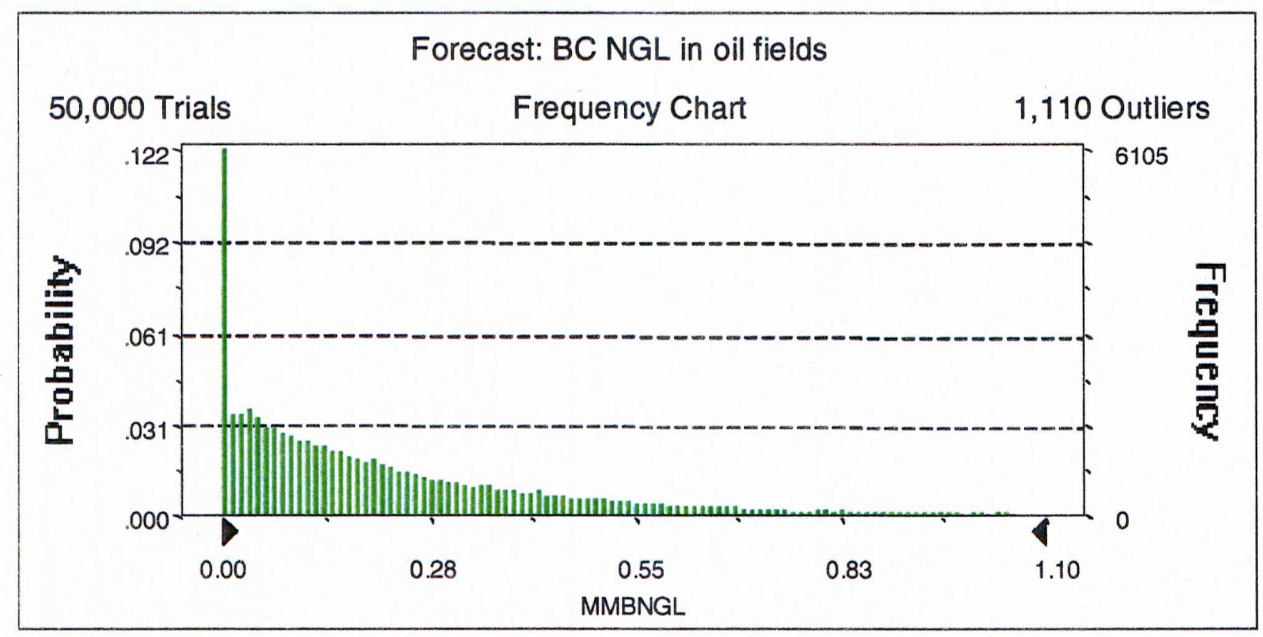


Forecast: NGL in Undiscovered Oil Fields in Big Cypress (cont'd)

Percentiles:

\begin{tabular}{r} 
Percentile \\
\hline $100 \%$ \\
$95 \%$ \\
$90 \%$ \\
$85 \%$ \\
$80 \%$ \\
$75 \%$ \\
$70 \%$ \\
$65 \%$ \\
$60 \%$ \\
$55 \%$ \\
$50 \%$ \\
$45 \%$ \\
$40 \%$ \\
$35 \%$ \\
$30 \%$ \\
$25 \%$ \\
$20 \%$ \\
$15 \%$ \\
$10 \%$ \\
$5 \%$ \\
$0 \%$
\end{tabular}

MMBNGL

0.00

0.00

0.00

0.02

0.04

0.05

0.07

$70 \%$

0.09

$60 \%$

0.11

$55 \%$

0.13

$50 \%$

0.16

$45 \%$

0.18

$40 \%$

0.21

$35 \%$

0.25

$30 \%$

0.29

$25 \%$

0.34

$20 \%$

0.40

$15 \%$

0.48

$5 \%$

0.60

$0 \%$

0.82

4.68

End of Forecast 


\section{Forecast: Gas in Undiscovered Gas Fields in Big Cypress}

Summary:

Display range is from 0.00 to $600.00 \mathrm{BCFG}$

Entire range is from 0.00 to $1,038.16 \mathrm{BCFG}$

After 50,000 trials, the standard error of the mean is 0.69

$\begin{array}{lr}\text { Statistics: } & \text { Value } \\ \text { Trials } & 50000 \\ \text { Mean } & 185.41 \\ \text { Median } & 153.54 \\ \text { Mode } & 0.00 \\ \text { Standard Deviation } & 153.73 \\ \text { Variance } & 23,633.26 \\ \text { Skewness } & 0.97 \\ \text { Kurtosis } & 3.77 \\ \text { Coefficient of Variability } & 0.83 \\ \text { Range Minimum } & 0.00 \\ \text { Range Maximum } & 1,038.16 \\ \text { Range Width } & 1,038.16 \\ \text { Mean Standard Error } & 0.69\end{array}$

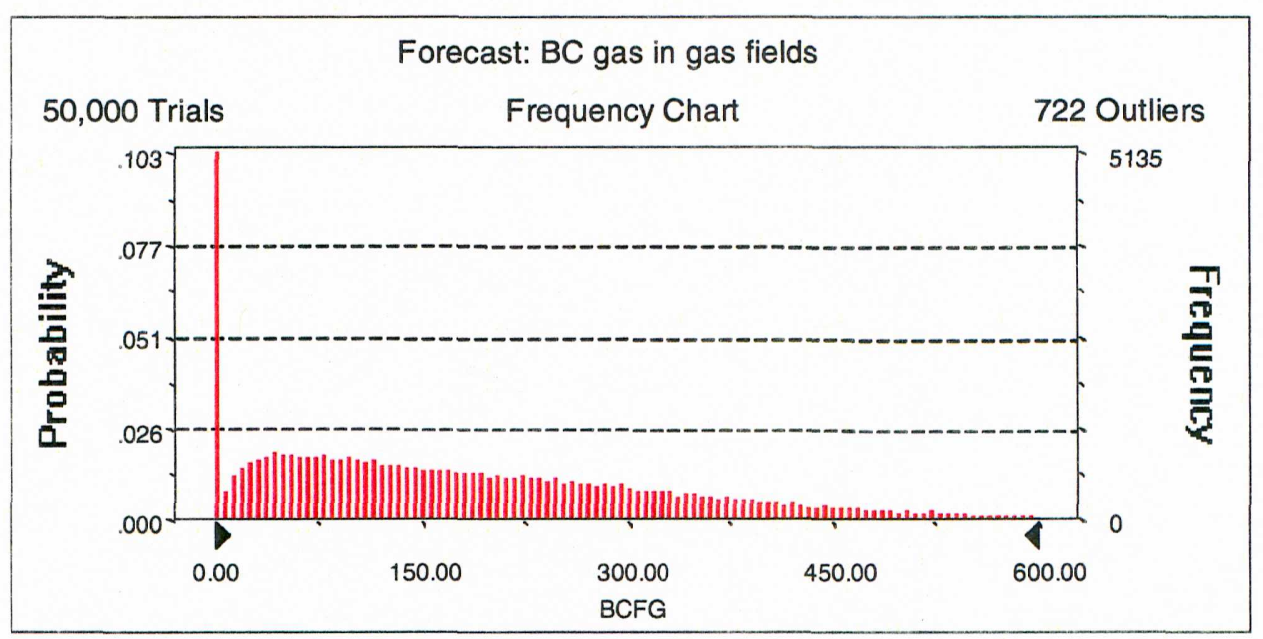


Pre-Punta Gorda Dolomite Gas and Oil

Monte Carlo Results

Forecast: Gas in Undiscovered Gas Fields in Big Cypress (cont'd)

Percentiles:

\begin{tabular}{rr} 
Percentile & BCFG \\
\hline $100 \%$ & 0.00 \\
$95 \%$ & 0.00 \\
$90 \%$ & 0.00 \\
$85 \%$ & 28.53 \\
$80 \%$ & 45.41 \\
$75 \%$ & 62.03 \\
$70 \%$ & 78.83 \\
$65 \%$ & 96.09 \\
$60 \%$ & 113.92 \\
$55 \%$ & 132.73 \\
$50 \%$ & 153.54 \\
$45 \%$ & 175.11 \\
$40 \%$ & 197.77 \\
$35 \%$ & 223.10 \\
$30 \%$ & 249.05 \\
$25 \%$ & 278.16 \\
$20 \%$ & 310.77 \\
$15 \%$ & 350.32 \\
$10 \%$ & 400.77 \\
$5 \%$ & 480.39 \\
$0 \%$ & $1,038.16$
\end{tabular}

End of Forecast 


\section{Forecast: Liquids in Undiscovered Gas Fields in Big Cypress}

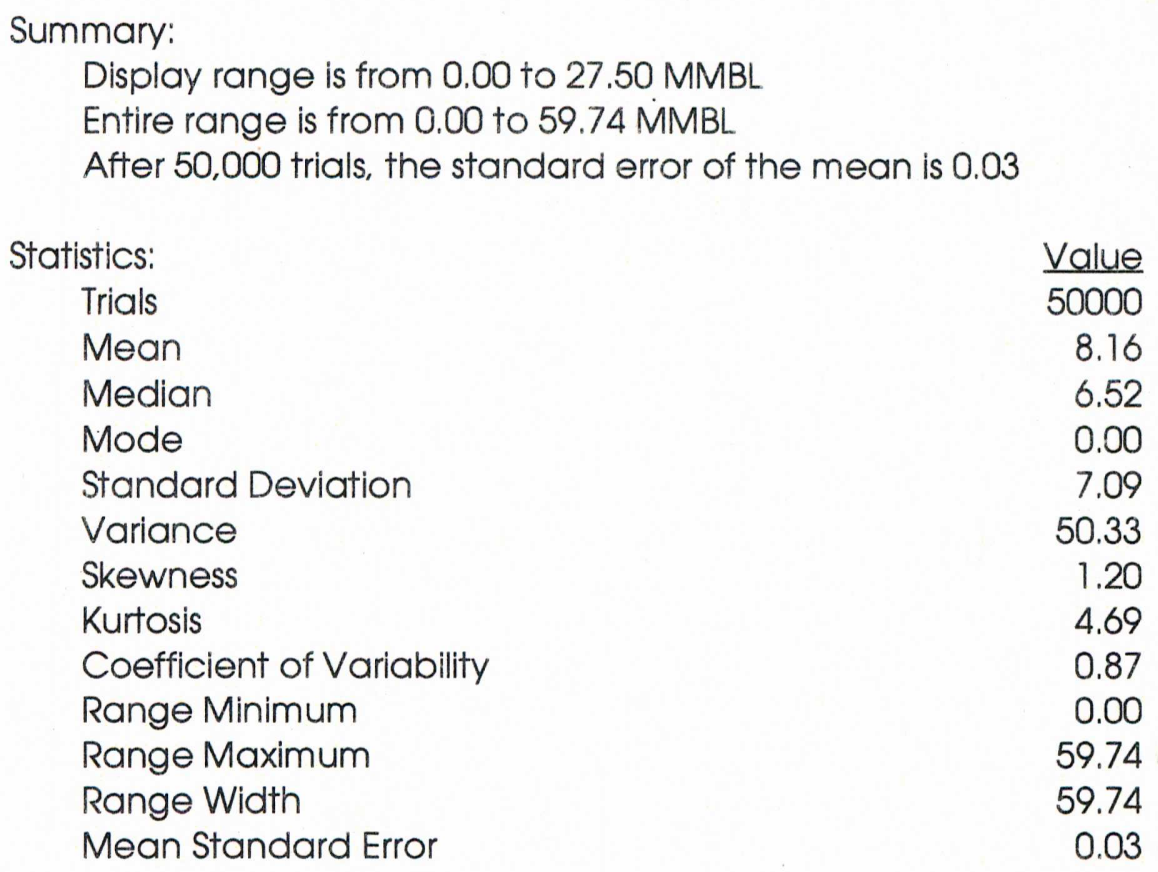

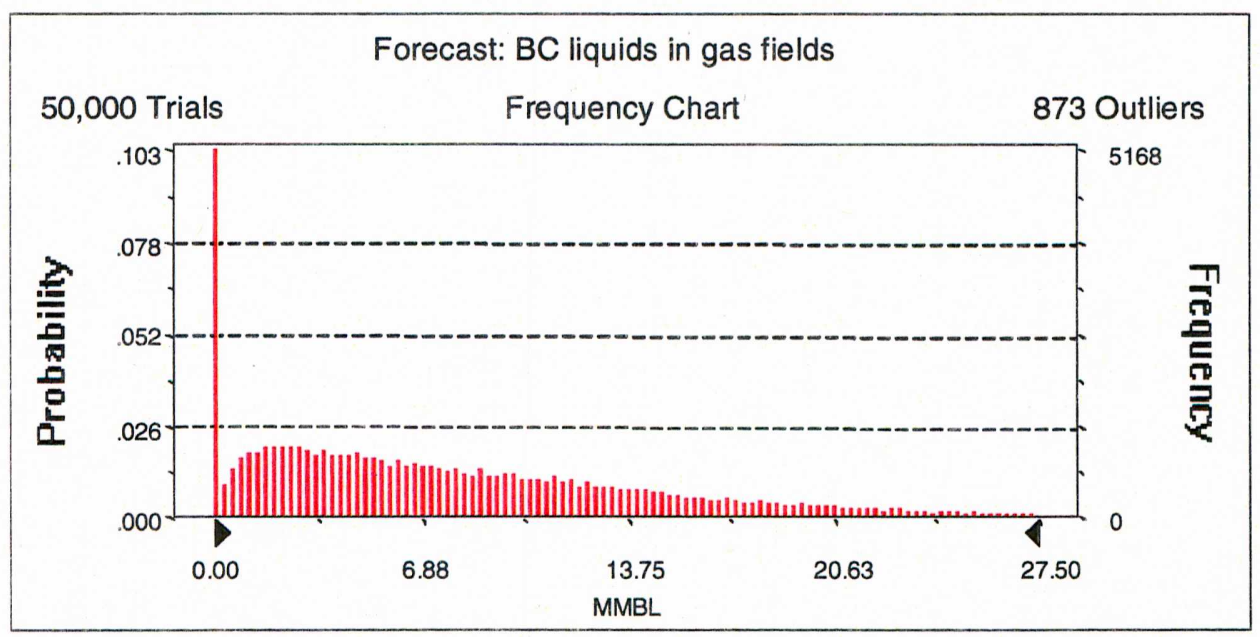


Forecast: Liquids in Undiscovered Gas Fields in Big Cypress (cont'd)

Percentiles:

\begin{tabular}{rr} 
Percentile & MMBL \\
\hline $100 \%$ & 0.00 \\
$95 \%$ & 0.00 \\
$90 \%$ & 0.00 \\
$85 \%$ & 1.20 \\
$80 \%$ & 1.92 \\
$75 \%$ & 2.61 \\
$70 \%$ & 3.31 \\
$65 \%$ & 4.07 \\
$60 \%$ & 4.83 \\
$55 \%$ & 5.63 \\
$50 \%$ & 6.52 \\
$45 \%$ & 7.46 \\
$40 \%$ & 8.48 \\
$35 \%$ & 9.58 \\
$30 \%$ & 10.74 \\
$25 \%$ & 12.03 \\
$20 \%$ & 13.56 \\
$15 \%$ & 15.43 \\
$10 \%$ & 17.99 \\
$5 \%$ & 21.94 \\
$0 \%$ & 59.74
\end{tabular}

End of Forecast 
50500201

Pre-Punta Gorda Dolomite Gas and Oil

Monte Carlo Results

\section{Assumptions}

\section{Assumption: Number of Undiscovered Oil Fields}

Triangular distribution with parameters:

Minimum

Likeliest

Maximum

24

Selected range is from 1 to 24

Mean value in simulation was 9

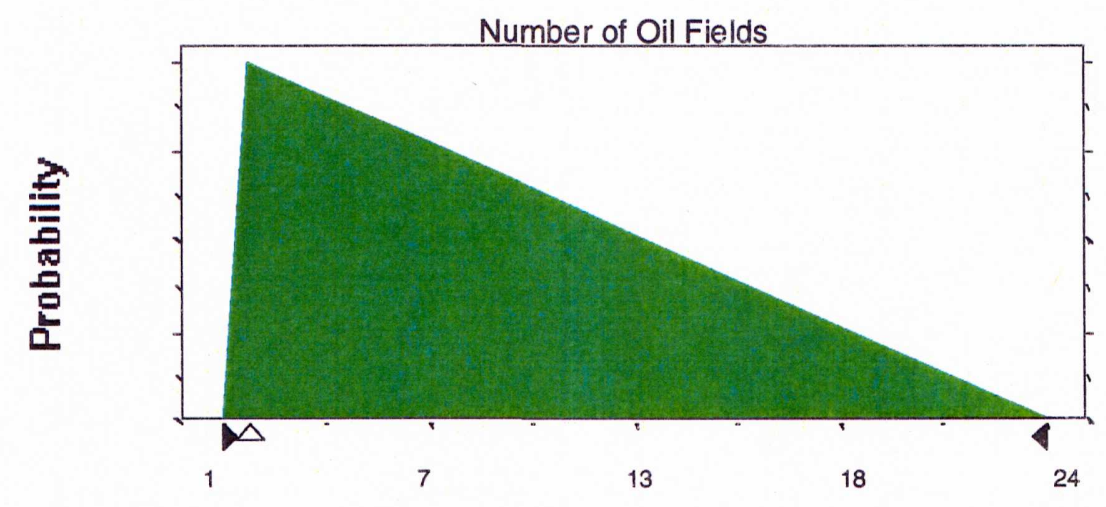

\section{Assumption: Sizes of Undiscovered Oil Fields}

Lognormal distribution with parameters: Shifted parameters

Mean

9.87

Standard Deviation

26.02

Selected range is from 0.00 to 299.50

Mean value in simulation was 9.38
10.37

26.02

0.50 to 300.00

9.88 
50500201

Pre-Punta Gorda Dolomite Gas and Oil

Monte Carlo Results

Assumption: Sizes of Undiscovered Oil Fields (cont'd)

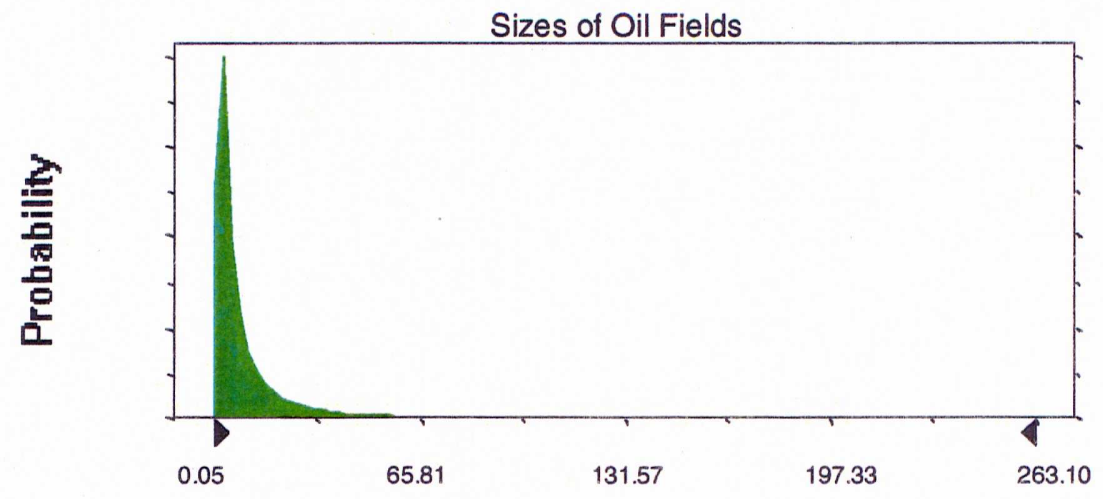

Assumption: GOR in Undiscovered Oil Fields

Triangular distribution with parameters:

Minimum

Likeliest

500.00

Maximum

666.67

$2,000.00$

Selected range is from 500.00 to $2,000.00$

Mean value in simulation was $1,056.58$

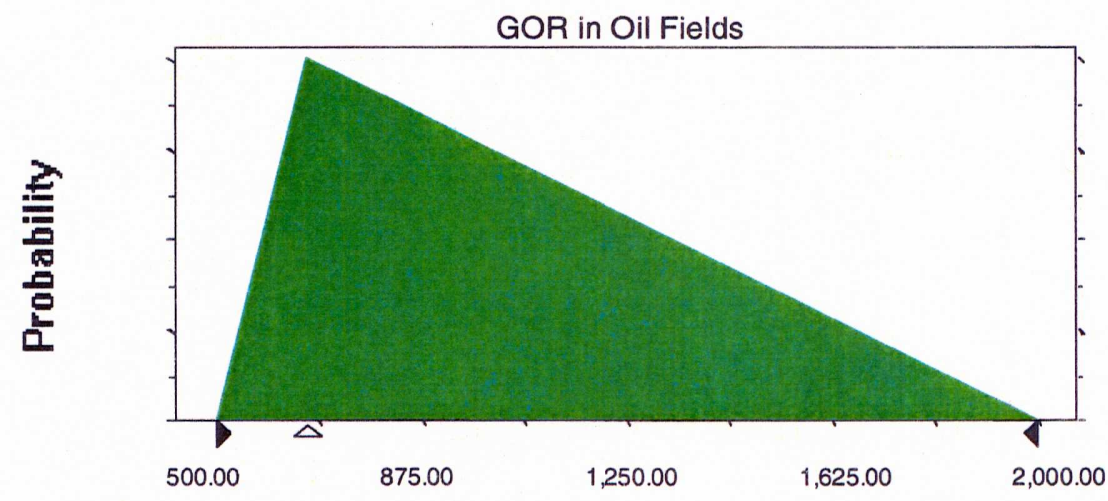


Pre-Punta Gorda Dolomite Gas and Oil

Monte Carlo Results

\section{Assumption: LGR in Undiscovered Oil Fields}

Triangular distribution with parameters:

Minimum

Likeliest

30.00

Maximum

Selected range is from 30.00 to 90.00

Mean value in simulation was 59.91

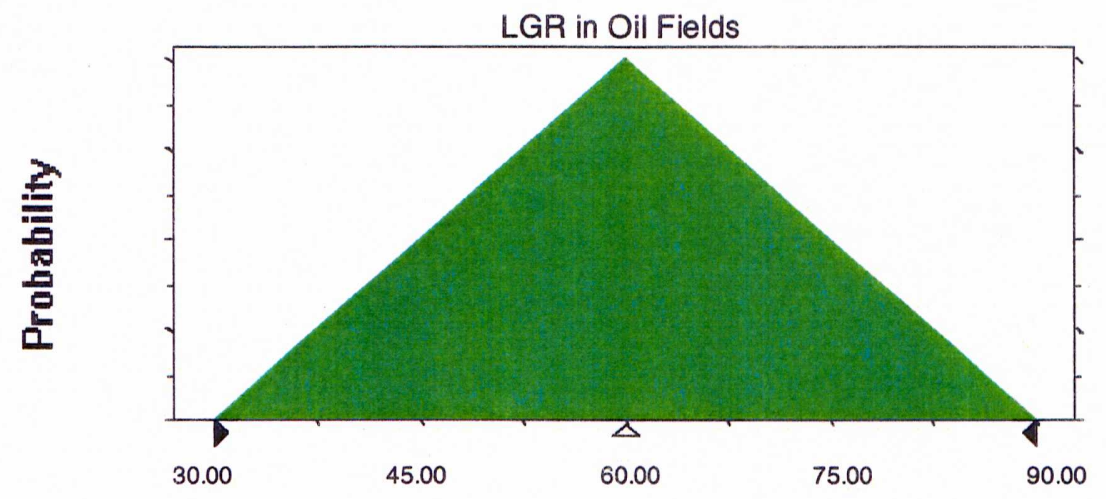

\section{Assumption: Number of Undiscovered Gas Fields}

Triangular distribution with parameters:

$\begin{array}{lr}\text { Minimum } & 2 \\ \text { Likeliest } & 7 \\ \text { Maximum } & 75\end{array}$

Selected range is from 2 to 75

Mean value in simulation was 28 
Assumption: Number of Undiscovered Gas Fields (cont'd)

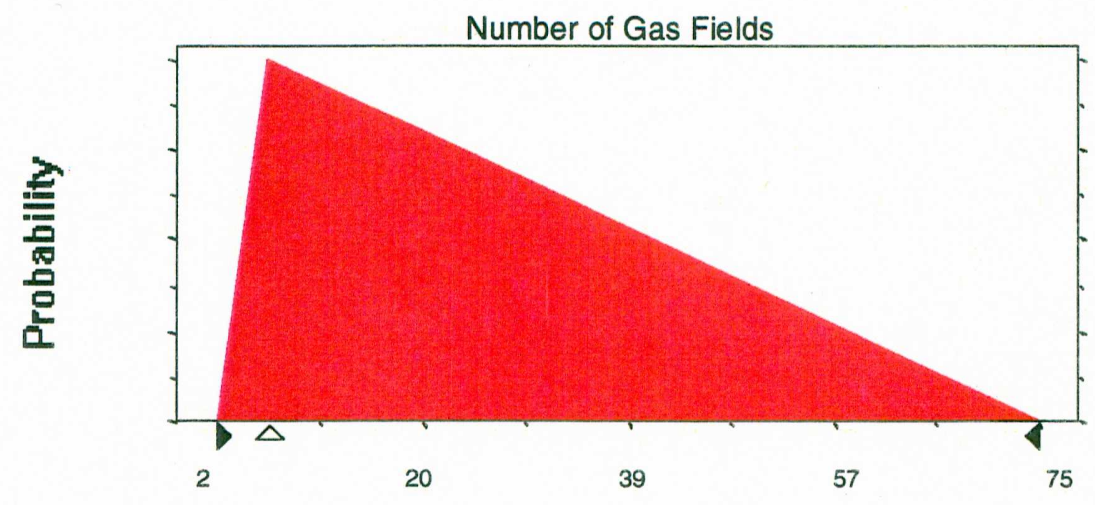

\section{Assumption: Sizes of Undiscovered Gas Fields}

Lognormal distribution with parameters: Shifted parameters

Mean

Standard Deviation

62.24

173.64

Selected range is from 0.00 to $1,997.00$

Mean value in simulation was 58.68
65.24

173.64

3.00 to $2,000.00$

61.68

Sizes of Gas Fields

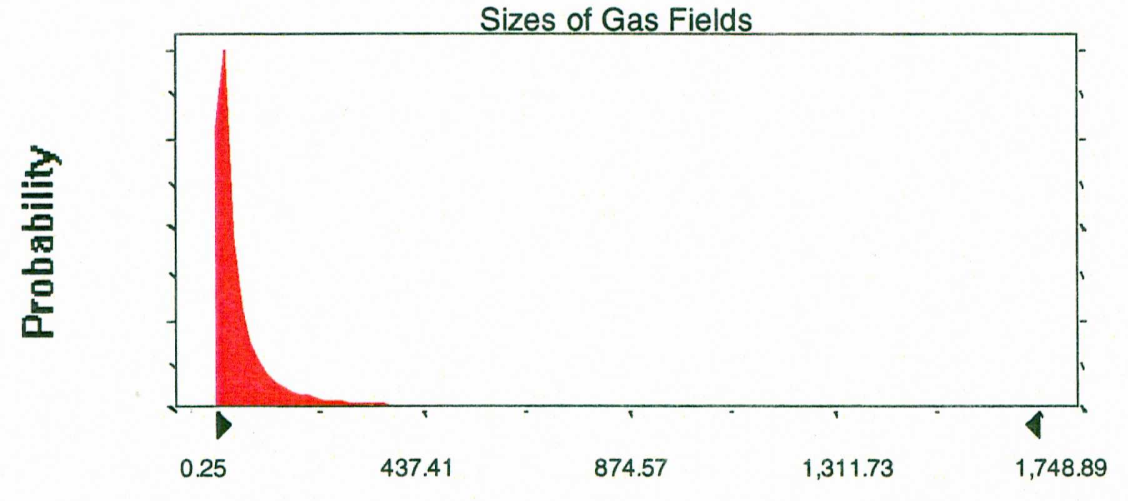




\section{Assumption: LGR in Undiscovered Gas Fields}

Triangular distribution with parameters:

Minimum

Likeliest

Maximum
22.00

44.00

66.00

Selected range is from 22.00 to 66.00

Mean value in simulation was 44.00

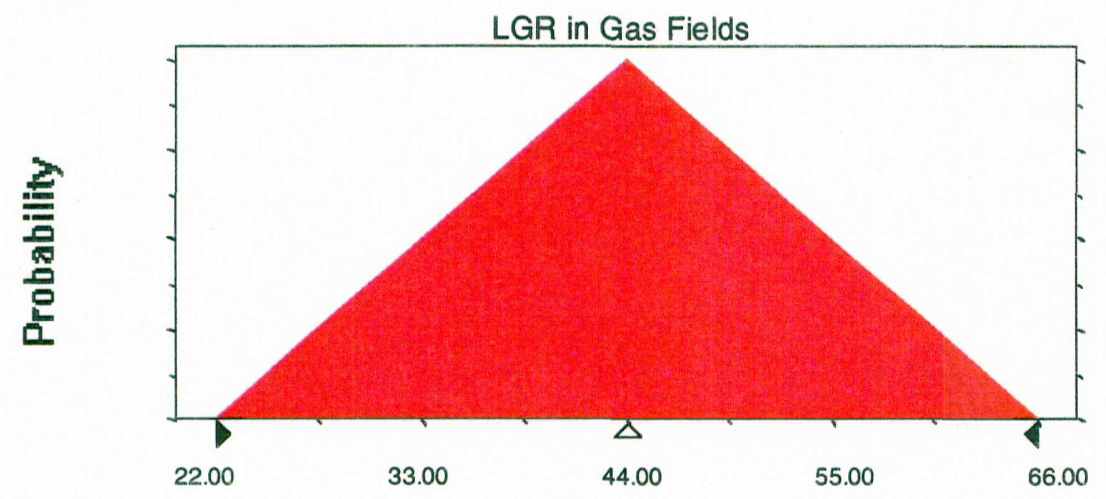

\section{Assumption: Undiscovered Oil \% in Big Cypress}

Triangular distribution with parameters:

Minimum

Likeliest

Maximum

Selected range is from 2.00 to 8.00

Mean value in simulation was 5.00
2.00

5.00

8.00 
Assumption: Undiscovered Oil \% in Big Cypress (cont'd)

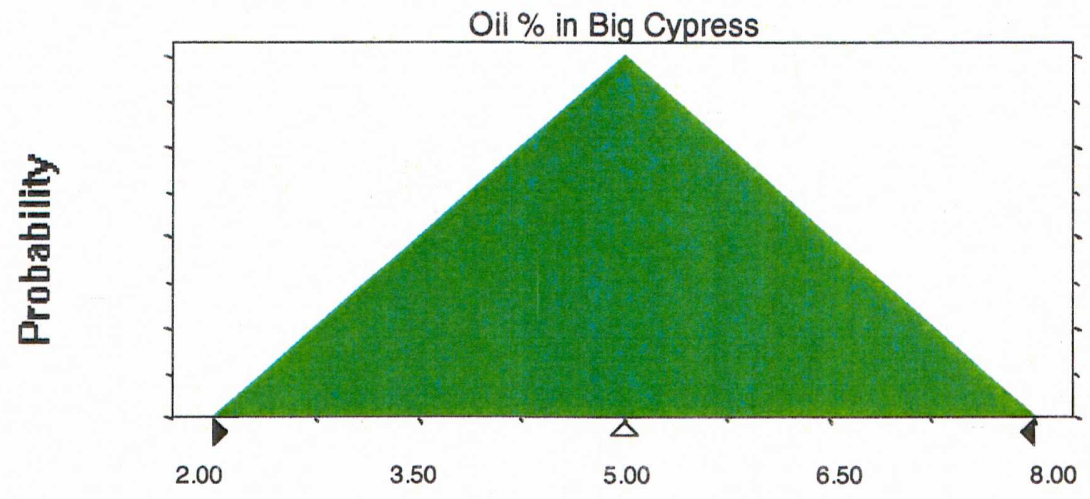

\section{Assumption: Undiscovered Gas \% in Big Cypress}

Triangular distribution with parameters:

$\begin{array}{lr}\text { Minimum } & 9.00 \\ \text { Likeliest } & 12.00 \\ \text { Maximum } & 15.00\end{array}$

Selected range is from 9.00 to 15.00

Mean value in simulation was 12.00

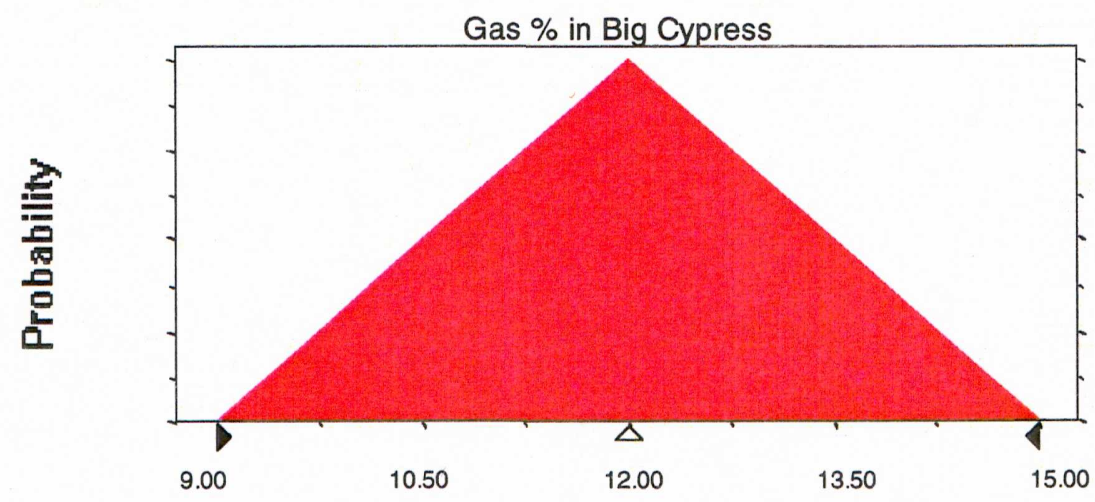

End of Assumptions

Simulation started on 5/25/00 at 9:32:52 